\title{
COLONIAL COSTUMING: REPRESENTATIONS OF PLAYING INDIAN IN PHOTOGRAPHS, SETTLER COLONIALISM AND THE APPROPRIATION OF NATIVE NORTH AMERICAN CULTURE
}

\author{
By \\ Hilkka Ingrid Forster \\ Bachelor of Fine Arts, Concordia University, Montreal QC, 2010 \\ A thesis \\ Presented to Ryerson University \\ in partial fulfillment of the requirements for the degree of \\ Master of Arts \\ in the Program of \\ Film and Photography Preservation and Collections Management
}

Toronto, Ontario, Canada, 2015

(C) Hilkka Ingrid Forster 2015 


\section{AUTHOR'S DECLARATION FOR ELECTRONIC SUBMISSION OF A THESIS}

I hereby declare that I am the sole author of this thesis. This is a true copy of the thesis, including any required final revisions, as accepted by my examiners.

I authorize Ryerson University to lend this thesis to other institutions or individuals for the purpose of scholarly research.

\section{Hilkka Ingrid Forster}

I further authorize Ryerson University to reproduce this thesis, by photocopying or by other means, in total or in part, at the request of other institutions or individuals for the purpose of scholarly research.

\section{Hilkka Ingrid Forster}

I understand that my thesis may be made electronically available to the public. 


\begin{abstract}
Hilkka Ingrid Forster

Colonial Costuming: Representations of Playing Indian in Photographs, Settler Colonialism and the Appropriation of Native North American Culture

Thesis (M.A.) Fall 2015 - Film and Photographic Preservation and Collections Management, Ryerson University
\end{abstract}

This thesis examines the cultural significance of "playing Indian" in photographs: the practice of non-Native peoples dressing up in Native North American costumes and posing for photographs. It addresses photographs made both inside and outside the studio of people playing Indian, during both the later part of the nineteenth and early twentieth centuries and looks at the extent to which these photographs reinforce settler colonial ideology prevalent within white society during this time period. Examples from two collections will be explored, portraits from the Notman photography collection at the McCord museum, which includes examples of white Europeans and North Americans dressing up in Native "costumes" and photographs of children playing Indian in the First Nations collection at the Archive of Modern Conflict Toronto. Themes of masculinity, nation-building, "Canadianness," and childhood in relation to indigeneity are explored by situating the photographs within their historical and cultural context and subsequently relating them to the already existing theories on playing Indian. 


\section{Acknowledgements}

I am very thankful for the many people who helped me throughout this thesis process. I would first like to thank my thesis advisors Thy Phu and Marta Braun for their guidance, advice and patience and for helping me refine my ideas and improve the clarity and precision of my argument and writing. I began with a very broad topic and many ideas and with Thy's help, was able to narrow down the scope of my thesis and research. I would also like to thank my second reader Alison Matthews David for her input and additional ideas, as well as her positive feedback.

I would like to acknowledge the Archive of Modern Conflict Toronto and thank Jill Offenbeck and Andrea Raymond for their time and for their assistance in finding this material and providing me with access to the First Nations collection. At the McCord museum in Montreal, I would like to thank archivist Nora Hague whose extensive knowledge of the Notman Photographic Archives contributed significantly to my understanding of Notman, the studio and the photographs I chose to work with.

I would like to thank my classmates for their valuable input and the supportive and engaging learning environment. Additionally, thank you to my copy editor Lisa Aitken, for helping me out at the very last minute. Cheers to everyone who listened to me talk endlessly about my subject and the importance of these photographs and to those who sent me photographs, news articles and literature and, most importantly, contributed to intellectual and stimulating conversations about "playing Indian."

To conclude, I would like to thank my parents for always supporting my academic endeavors and for always listening to all of my abstract ideas. 
To the First Nations, Inuit and Métis peoples of Canada. 


\section{Table of Contents}

1. Author's Declaration........................................................ ii

2. Abstract...........................................................................

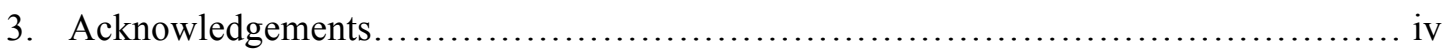

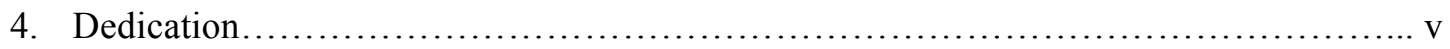

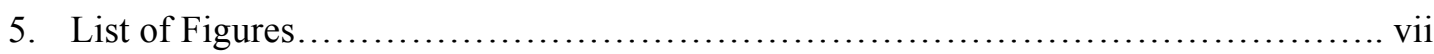

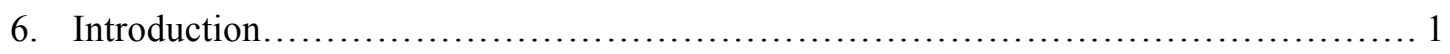

7. Methodology and Notes................................................... 12

8. Chapter 1: Native North American Costumes in the Notman Photographic Archives.... 15

9. Chapter 2: Children Playing Indian in the AMC Toronto Collection.................. 38

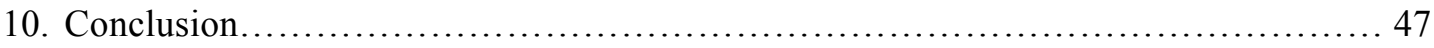

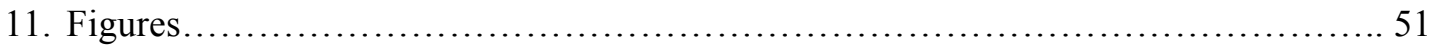

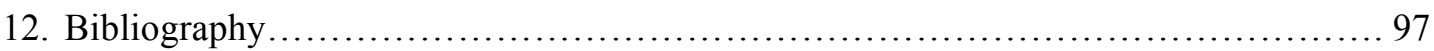




\section{List of Figures}

1. Colour postcard of three "Apache Warriors," 1899. Detroit Photographic Company. Personal Collection.

2. Chief Joseph-Nez Percé, ca.1903. Edward S. Curtis. Gelatin silver print. Library of Congress Prints and Photographic Division.

3. Promotional photograph for the film Mohawk starring Scott Brady, 1956. $20^{\text {th }}$ Century Fox Film Corp. Gelatin silver print. First Nations Collection at the Archive of Modern Conflict Toronto.

4. Geronimo (Guiyatle)-Apache, 1898. Frank A. Rinehart. Platinum print. First Nations Collection at the Archive of Modern Conflict Toronto.

5. Sitting Bull and Buffalo Bill, Montreal, QC, 1885. William Notman \& Son. Dry gelatin silver glass plate negative. Notman Photographic Archives at the McCord Museum.

6. J. Whitney and H. Lyman, posed for a composite, Montreal, QC, 1870. William Notman \& Son. Dry gelatin silver glass plate negative. Notman Photographic Archives at the McCord Museum.

7. Skating Carnival, Victoria Rink, painted composite, Montreal, QC, 1870. William Notman \& Son. Oil painted albumen print on canvas. Notman Photographic Archives at the McCord Museum.

8. Mr. Reynolds as "Quewaygoosquequamteros," posed for composite, Montreal, QC, 1870. William Notman \& Son. Albumen print mounted on paper. Notman Photographic Archives at the McCord Museum.

9. Welcome to the Studio: An Allegory for Artistic Reflection and Transformation, 2014. Kent Monkman. Acrylic on canvas. Courtesy of the McCord Museum.

10. Sarcee Indian Camp, Calgary, AB, for the Canadian Pacific Railway, 1892. William Notman \& Son. Gelatin silver print mounted on card. Notman Photographic Archives at the McCord Museum.

11. Miss Plimsoll as "Indian Woman," posed for a composite, Montreal, QC, 1870. William Notman. Albumen print mounted on paper. Notman Photographic Archives at the McCord Museum.

12. James Fletcher as "Che-oc-che-moo-che" or "White Maple Leaf, the Micmac" and friend, posed for a composite, Montreal, QC, 1881. Notman \& Sandham. Albumen print mounted on paper. Notman Photographic Archives at the McCord Museum.

13. Cover of the book Masquerade and Carnival, 1892. The Butterick Publishing Company Limited. Courtesy of the McCord Museum.

14. Page from the book Masquerade and Carnival, depicting "Oriental" Costumes, 1892. The Butterick Publishing Company Limited. Courtesy of the McCord Museum. 
15. Page from the book Masquerade and Carnival, depicting "North American Indian" and "Pocahontas" Costumes, 1892. The Butterick Publishing Company Limited. Courtesy of the McCord Museum.

16. Cover of invitation to the "Historical Costume Reception and Ball" for the Chateau Ramezay, Montreal, QC, 1898. Courtesy of the McCord Museum.

17. Page from the invitation to the "Historical Costume Reception and Ball" for the Chateau Ramezay, Montreal, QC, 1898. Courtesy of the McCord Museum.

18. Charles Bouthillier in "Indian" costume, Montreal, QC, 1865. William Notman. Albumen print mounted on paper. Notman Photographic Archives at the McCord Museum.

19. Mr. Wright in "Indian" costume, Montreal, QC, 1881. Notman \& Sandham. Albumen print mounted on paper. Notman Photographic Archives at the McCord Museum.

20. F.A. Wise in "Indian" costume, Montreal, QC, 1881. Notman \& Sandham. Albumen print mounted on paper. Notman Photographic Archives at the McCord Museum.

21. Lord Dunmore in "Indian" costume, painted photograph, 1862. William Notman. Albumen print mounted on paper. Notman Photographic Archives at the McCord Museum.

22. Mr. Jefferson, $16^{\text {th }}$ Regiment, in costume, Montreal, QC, 1863. William Notman. Albumen print mounted on paper. Notman Photographic Archives at the McCord Museum.

23. Snapshot portrait of a man in Plains-inspired Native North American costume, $20^{\text {th }}$ century. Gelatin silver print. First Nations Collection at the Archive of Modern Conflict Toronto.

24. Page from the book Masquerade and Carnival, depicting "North American Indian" costume, 1892. The Butterick Publishing Company Limited. Courtesy of the McCord Museum.

25. Photograph of microfilm of Mr. Bourdon as "Blackfeet Indian Chief," Montreal, QC, 1872. William Notman. Albumen print mounted on paper. Notman Photographic Archives at the McCord Museum.

26. Photograph of microfilm of Mr. Bourdon as "Kingtail Indian Chief," Montreal, QC, 1872. William Notman. Albumen print mounted on paper. Notman Photographic Archives at the McCord Museum.

27. Studio Portrait of a child dressed in Plains-inspired Indian costume with tomahawk and face paint, 1933. Inscription on recto reads: "LuLu." Gelatin silver print on matte paper. First Nations Collection at the Archive of Modern Conflict Toronto.

28. Andrew A. McCulloch costumed as an "Indian," painted photograph, Montreal, QC, 1863. William Notman and John Arthur Fraser. Albumen print mounted on cardboard, painted with watercolour. Notman Photographic Archives at the McCord Museum. 
29. Andrew A. McCulloch, costumed for Chateau de Ramezay Ball, Montreal, QC, 1898. William Notman \& Son. Dry gelatin silver glass plate negative. Notman Photographic Archives at the McCord Museum.

30. M. de Blois Thibaudeau, costumed for the Chateau de Ramezay Ball, Montreal, QC, 1898. William Notman \& Son. Dry gelatin silver glass plate negative. Notman Photographic Archives at the McCord Museum.

31. Henry George Vennor in "Indian” costume, Montreal, QC, 1865. William Notman. Albumen print mounted on paper. Notman Photographic Archives at the McCord Museum.

32. Robert Summerhayes and ladies tobogganing, Montreal, QC, ca.1875. William Notman. Albumen print mounted on paper. Notman Photographic Archives at the McCord Museum.

33. Caribou Hunting, “The Hunter, ” Montreal, QC, 1866. William Notman. Albumen print mounted on paper. Notman Photographic Archives at the McCord Museum.

34. Caribou Hunting, “Arrival at Camp,” Montreal, QC, 1866. William Notman. Albumen print mounted on paper. Notman Photographic Archives at the McCord Museum.

35. A. G. Lord in skating party costume, posed for a composite, Montreal, QC, 1881. Notman $\&$ Sandham. Albumen print mounted on paper. Notman Photographic Archives at the McCord Museum.

36. William George Beers in "Indian" costume, Montreal, QC, 1865. William Notman. Albumen print mounted on paper. Notman Photographic Archives at the McCord Museum.

37. Family photograph of adult and children "playing Indian," ca.1950. Unknown photographer. Gelatin silver print. Personal Collection.

38. Children in costume "playing Indian" out in a field with teepees, late $19^{\text {th }}$ to early $20^{\text {th }}$ century. Cyanotype photograph on fiber paper. First Nations Collection at the Archive of Modern Conflict Toronto.

39. Stereocard of a young boy in costume "playing Indian" kneeling with a bow and arrow, late $19^{\text {th }}$ century. Inscription on recto reads: "Tis a boys delight to play Indian." Gelatin silver print on card. First Nations Collection at the Archive of Modern Conflict Toronto.

40. Stereocard of a young boy in costume "playing Indian" kneeling and facing the camera, late $19^{\text {th }}$ century. Gelatin silver print on card. First Nations Collection at the Archive of Modern Conflict Toronto.

41. Stereocard of a young boy in cowboy costume riding a toy horse, late $19^{\text {th }}$ century. Inscription on recto reads: "A Juvenile Cowboy." Gelatin silver print on card. First Nations Collection at the Archive of Modern Conflict Toronto. 
42. Studio portrait of a young boy dressed in "Indian" costume, kneeling and holding a rifle, late $19^{\text {th }}$ century. Albumen print mounted on card. First Nations Collection at the Archive of Modern Conflict Toronto.

43. Photograph of a young boy dressed in "Indian" costume with a shield, aiming a bow and arrow, early $20^{\text {th }}$ century. Gelatin silver print. First Nations Collection at the Archive of Modern Conflict Toronto.

44. Grouping of six photographs

Clockwise from top left:

Two children in front of house in costume "playing Indian" in the snow, $20^{\text {th }}$ century. Gelatin silver print. First Nations Collection at the Archive of Modern Conflict Toronto.

Two young boys dressed in "Indian" costume holding shields, early $20^{\text {th }}$ century. Gelatin silver print. First Nations Collection at the Archive of Modern Conflict Toronto.

Photograph of a young boy dressed in "Indian" costume with a shield, aiming a bow and arrow, early $20^{\text {th }}$ century. Gelatin silver print. First Nations Collection at the Archive of Modern Conflict Toronto.

A young boy in "Indian" costume standing in a field of sand and grass, 1908. Inscription on verso reads: "Elmer at Plum Island Aug $9^{\text {th }} 1908$." Gelatin silver print mounted on card. First Nations Collection at the Archive of Modern Conflict Toronto.

Studio portrait of a young boy dressed in Plains-inspired Indian costume with tomahawk and face paint, 1933. Inscription on recto reads: "LuLu." Gelatin silver print on matte paper. First Nations Collection at the Archive of Modern Conflict Toronto.

Studio portrait of a young boy dressed in "Indian" costume, kneeling and holding a rifle, late $19^{\text {th }}$ century. Albumen print mounted on card. First Nations Collection at the Archive of Modern Conflict Toronto.

45. A young boy in "Indian" costume standing in a field of sand and grass, 1908. Inscription on verso reads: "Elmer at Plum Island Aug $9^{\text {th }} 1908$." Gelatin silver print mounted on card. First Nations Collection at the Archive of Modern Conflict Toronto.

46. Studio portrait of a girl dressed in "Indian" costume, sitting on a tapestry and holding a tomahawk, late $19^{\text {th }}$ to early $20^{\text {th }}$ century. Gelatin silver print mounted on card. First Nations Collection at the Archive of Modern Conflict Toronto.

47. Studio portrait of two girls and one boy dressed in Plains "Indian" costume, posed against an "outdoor" studio set. Inscription on recto reads: "Francis-Colorado Springs, 1909." Gelatin silver print. First Nations Collection at the Archive of Modern Conflict Toronto.

48. Eight children dressed in Plains-inspired "Indian" costume, one aiming a bow and arrow and three children playing hand drums, $20^{\text {th }}$ century. Gelatin silver print. Record Photography Collection of the University of Waterloo Library. First Nations Collection at the Archive of Modern Conflict Toronto. 
49. Real photo postcard of family of adults and children playing "Indians" and "settlers," where one man is being scalped and the others have their hands tied, ca.1915. Gelatin silver print. First Nations Collection at the Archive of Modern Conflict Toronto.

50. Screen capture of @suicidegirls instagram account of a photograph posted of a model wearing a long feathered war bonnet, 2015. @SGBlackheartburlesque. Digital photograph. Personal Collection.

51. A music fan in a Native American headdress at the Isle of Wight Festival in the United Kingdom, June 2015. Jim Ross/Invision. Digital Photograph.

http://www.thestar.com/entertainment/2015/07/15/ontario-alberta-music-festivals-banwearing-first-nations-headdresses.html 


\section{Introduction}

But the Dead Indians I'm talking about are not the deceased sort. Nor are they all that inconvenient. They are the stereotypes and clichés that North America has conjured up out of experience and out of its collective imaginings and fears.

-Thomas King, The Inconvenient Indian

This thesis examines the cultural significance of "playing Indian" in photographs: the practice of non-Native peoples dressing up in Native North American costumes and posing for photographs. More specifically, it addresses photographs made both inside and outside the studio of people "playing Indian," during both the later part of the nineteenth and early twentieth centuries, which coincided with an existing visual culture in Europe and North America that was fascinated with a highly romanticized image of the "Indian" and at the height of colonial photography of Native peoples.

I use "Indian" as a reflection of the time during which the photographs I am discussing were made and do not intend, in using this or any related terminology, to be derogatory, or offensive. Robert Berkhofer Jr., in his book The White Man's Indian, points out that one of the common trends in scholarship on this subject has been to use the term "Indian" to describe all aboriginal peoples of North America, as if they belonged to one nation, or identity. ${ }^{1}$ The same could be said for the term "Native." The term "Indian" was originally used by Columbus when he mistakenly thought he arrived in the Indies and, upon meeting indigenous peoples in the Caribbean, called them "los Indios." ${ }^{2}$ Both "Indian" and "Native" are blanket terms and not ideal, as they do not properly define the multitude of cultures that they are intended to represent. For the purposes of this thesis, however, I will be using general terms such as Native, to refer to all Native North American cultures, and Aboriginals referring to Canadian cultures and First Nations, when discussing Canadian cultures that do not include the Inuit and the Métis, as well as the term indigenous. Native cultures are often referred to as tribes, or nations, but both terms

\footnotetext{
${ }^{1}$ Robert F. Berkhofer Jr., The White Man's Indian: Images of the American Indian from Columbus to the Present (New York: Alfred A. Knopf, Inc., 1978), 26.

${ }^{2}$ Colin G. Calloway, First Peoples: A Documentary Survey of American Indian History (Boston: Bedford/St. Martin's, 2008),11.
} 
seem to be used interchangeably. A nation may also comprise of individual tribes. The correct use of this terminology is a complex issue and my goal is to try my best to use the appropriate terminology throughout my thesis.

The image of the Indian that we are most familiar with to this day was contingent upon the medium of photography. Beginning in the mid-to-late nineteenth century, Native North Americans were put on display at exhibitions, photographed at world fairs and were documented, along with other subjects of colonialism, for ethnographic study to reinforce notions of the Other and of racial hierarchy. Colonialism reached its height during the mid-nineteenth to early twentieth centuries, at a time when photography was developing as a documentary medium.

Native North Americans have faced a long history of cultural appropriation in photography. Widely distributed stereographs made both in Canada and the United States depicted views and portraits of aboriginal peoples. They appeared in early travel and expeditionary collections as "savages," noble or otherwise, and their faces were used on postcards (fig.1). Eventually, an image of the Indian, very much shaped by European and North American ideas, made its way into advertisements and onto tobacco containers. Many of these images were a direct result of the conquest of the American West. ${ }^{3}$ There were a number of photographers working on topographical government survey projects in Canada and the United States during the late nineteenth and early twentieth century, who ended up photographing Native North Americans. Geological surveying in Canada also played a key role in the development of the Canadian mineral and coal industries, where contact between settlers and Native peoples occurred. After the Civil War, military-related survey teams were assigned to map large territories in the West and document geographical and cultural information. These surveys, however, also had a political and economic agenda and eventually led to the displacement of Native peoples and the conquest of their land and resources. Photographs of Natives taken during

\footnotetext{
${ }^{3}$ Ulrich W. Hiesinger, Indian Lives: A Photographic Record from the Civil War to Wounded Knee (Munich and New York: Prestel-Verlag, 1994), 14.
} 
these survey projects were often romanticized and idealized and did not accurately represent the way in which they were treated, or the growing tensions at this colonial contact zone, as settlers took over Native territory.

Eventually, the constructed image of the "Indian" as the "noble savage" became widespread, as we see represented in the familiar pictorial photographs of Edward S. Curtis (both authentic and imagined) ${ }^{4}$ and in later twentieth-century Hollywood films (fig. 2 and fig. 3). The vanishing race theory was ideal for photographers, as it gave them an excuse to "document" these cultures before they "disappeared" completely. Bonnie M. Miller, an American historian, in her journal article “The Incoherencies of Empire: The 'Imperial' Image of the Indian at the Omaha World's Fairs of 1898-99," points out that the images made by photographers such as Frank A. Rinehart, were specifically commissioned to further the notion of ethnographic hierarchy, the romanticized image of the "tamed noble savage," and the idea of a vanishing race (fig. 4). Miller emphasizes the assimilationist vision that Rinehart promoted and the real purpose behind making the photographs. Rinehart was commissioned by the US government to document the Native leaders who were invited to attend a convention at the Omaha Fair. The intention was to create an

\footnotetext{
${ }^{4}$ Hans Christian Adam, Edward S. Curtis (Köln: Taschen, 1999), 23-37. Between 1907 and 1930, Edward S. Curtis produced a twenty-volume encyclopaedia titled The North American Indian, comprised of both images and text, including over seven hundred photogravures. The series is considered an extensive anthropological and ethnographic investigation and account of the numerous Native North American tribes. Curtis's early photographs of Natives involved restaging battles, ceremonies and cultural practices, attempting to remove all signs of assimilation and colonial experience. Nancy Hathaway, Native American Portraits 1862-1918 (San Francisco: Chronicle Books, 1990), 12. Curtis, influenced by the romantic aesthetic associated with pictorialism, put together an extensive collection of what some scholars have considered historically and culturally inaccurate photographs of various Native tribes across the West. The value of Curtis's work and the way in which it has been interpreted continues to be a contentious issue. There is a divide among scholars, whom, on one hand, believe that Curtis's work is an extremely important anthropological investigation and documentation of Native North American cultures during a time period where these cultures were changing drastically, due to settler colonialism and forced assimilation, and on the other, believe that his work cannot be considered as a true anthropological study, because his photographs were, in many cases, very staged and contrived. Anne Maxwell, Colonial Photography and Exhibitions: Representations of the Native and the Making of European Identities (Leicester: Leicester University Press, 2000), 11. Curtis focused on photographing Natives in such a way that the images did not reflect the presence of the Western world and were of a highly romanticized and nostalgic nature.
} 
archive of photographs of Native leaders from various tribes for anthropological preservation. ${ }^{5}$

Rinehart believed that his documentation of Native peoples was essential stating that,

"In a remarkably short time, education and civilization will stamp out the feathers, beads and paint and the Indian of the past will live but in memory and pictures."

The popularity of Native North Americans as photographic subjects and what I am going to call the commercialization of the "Indian" image was later furthered by Hollywood films, which depicted epic showdowns between Natives as bloodthirsty savages and cowboys as heroes of the Wild West. ${ }^{7}$ Jacquelyn Kilpatrick in her book Celluloid Indians: Native Americans and Film suggests that this constructed image of the Indian had already been established and "entrenched in the new American mythology" of the nineteenth century, much to the credit of Buffalo Bill Cody and his touring Wild West Show. ${ }^{8}$ The Wild West Show included many Lakota, who were members of the Sioux Nation, among whom for a time, included Chief Sitting Bull, the last chief of the Sioux peoples to surrender to American authorities. It is unlikely that both American and European spectators who enjoyed the Buffalo Bill Show really knew, or wanted to acknowledge, how the Sioux people were being treated, how they were forced to live on reserves, sell off their land, to give up their cultural practices, and to assimilate. ${ }^{9}$ The Sioux who toured with the Wild West Show were also playing Indian, asked to re-enact battles in which they had actually lost many of their own warriors, chiefs and people. The elaborately staged scenes reflected the western frontier, where Buffalo Bill Cody always came out the hero. ${ }^{10}$ Among the most popular Notman Studio portraits, which I discuss in Chapter 1, are those of

\footnotetext{
5 Bonnie M. Miller, "The Incoherencies of Empire: The "Imperial” Image of the Indian at the Omaha World's Fairs of 1898-99," Journal of American Studies 49, no. 3/4 (Fall/Winter 2008): 2, $39-62$.

${ }^{6}$ Miller, "The Incoherencies of Empire: The "Imperial” Image of the Indian at the Omaha World's Fairs of 1898-99," 39-62.

7 Jacquelyn Kilpatrick, Celluloid Indians: Native Americans and Film (Lincoln and London: University of Nebraska Press, 1999), 12.

${ }^{8}$ Kilpatrick, Celluloid Indians Native Americans and Film, 12.

${ }^{9}$ Dee Brown, Bury My Heart at Wounded Knee: An Indian History of the American West ( New York: Picador, Henry Holt and Company, 1970).

${ }^{10}$ Daniel Francis, The Imaginary Indian: The Image of the Indian in Canadian Culture (Vancouver: Arsenal Pulp, 1992), 105.
} 
Sitting Bull and Buffalo Bill Cody, made in 1885 (fig. 5). Daniel Francis, in his book The Imaginary Indian: The Image of the Indian in Canadian Culture, points out that "prior to the Hollywood movie, no other entertainment medium was as popular a purveyor of the Indian image as the Wild West Show.",11

According to Philip Deloria, there is a connection between "playing Indian" and American identity; the establishment of what Deloria refers to as an "aboriginal closeness" enables settler colonials to establish connections to the land they have conquered and wrested from Native peoples. ${ }^{12}$ Although Deloria focuses on the American context, a similar logic was at work in Canada, where settler colonialists also established their sense of identity and nationalism through "Indian" emulation. Building on Deloria's work, Sharon Wall, in her journal article “Totem Poles, Teepees, and Token Traditions: playing Indian at Ontario Summer Camps," attributes the desire to go to camp and "play Indian" as an anti-modern behavior, a reaction to urbanization and industrialization:

So also at Ontario camps, "going Native" had little to do with honouring (or even accurately portraying) Aboriginal tradition, but much to do with seeking a balm for the non-Native experience of modernity. Above all, at summer camp, playing Indian reflected a modern desire to create a sense of belonging, community, and spiritual experience by modeling anti-modern images of Aboriginal life. ${ }^{13}$

The act of white people dressing up in Indian costume and appropriating the cultural dress of Native North Americans reflects the dominant attitudes of North Americans and Europeans towards their colonized people. The costumes worn in these photographs are a direct representation of the constructed and singular image of the Indian referred to by scholars such as Robert F. Berkhofer Jr. and Daniel Francis.

When I began this research, I had intended on working solely with a collection of photographic material from the Archive of Modern Conflict (AMC), specifically on a grouping of

\footnotetext{
${ }^{11}$ Francis, The Imaginary Indian, 106.

${ }_{12}^{12}$ Philip J. Deloria, Playing Indian (New Haven and London: Yale University Press, 1998), 5.

${ }^{13}$ Sharon Wall, "Totem Poles, Teepees, and Token Traditions: playing Indian at Ontario Summer Camps," The Canadian Historical Review 86, no. 3 (September 2005): 2.
} 
photographs that depicted people playing Indian in various contexts dating from the last half of the nineteenth century to the early twentieth century. I began thinking about whether or not these types of photographs had previously been addressed and, if so, to what degree. To what extent do they exist in other collections? I then extended my search for similar examples in other collections and found a substantial grouping within the Notman Studio archive at the McCord museum in Montreal and at the Archive of Modern Conflict in Toronto.

Some critical attention has been given to the Notman portraits throughout the book Magnificent Entertainments: Fancy Dress Balls of Canada's Governors General 1876-1898, by Cynthia Cooper, the curator of costume and textiles at the McCord museum. In this book, Cooper includes photographs from both the Notman archive as well as the W.J Topley collection from the National Archives of Canada. Many of the subjects, seen in both the Topley and Notman studio portraits dressed in Native costumes, did so in relationship to fancy dress balls. In her discussion of a photograph of Hayter Reed dressed as an Iroquois for a fancy dress ball, (Reed was the Deputy Superintendent General of Indian Affairs at the time), Cooper suggests that:

The "Indians" which Reed and his group imitated had nothing to do with the nature of aboriginal peoples; rather, they were part and parcel of the mythology of the Canadian past; the heroism of the other historical figures was bolstered only in the presence of this "other," in all its barbaric and savage glory." 14

From this statement, one could infer that Cooper has engaged in this theoretical framework on the subject of playing Indian. She does so by reinforcing that those dressing in Native costumes for fancy dress balls were doing so nostalgically and as an assertion of colonial conquest.

This thesis will look at examples from two collections. The first section will focus on the studio portraits from the Notman photography collection at the McCord museum, which includes a substantial number of examples of white Europeans and North Americans dressing up in Native "costumes" (fig. 6). The second section will specifically look at the aforementioned examples of children playing Indian found in the Archive of Modern Conflict. Although these photographs

\footnotetext{
${ }^{14}$ Cynthia Cooper, Magnificent Entertainments: Fancy Dress Balls of Canada's Governors General 18761898 (Ottawa: Goose Lane Editions, Canadian Museum of Civilization, 1997), 88.
} 
belong to a much larger framework of people playing Indian, of which there are countless visual examples both past and present, for the purpose of this thesis I have focused on answering the following questions: What is the cultural significance of these photographs in both the Notman archive and the Archive of Modern Conflict of non-Native peoples dressed up in Native North American costume? What relationship do they have to the greater context of people playing Indian?

This thesis explores the extent to which photographs of people playing Indian in both the Notman studio collection and the Archive of Modern Conflict reinforce settler colonial ideology prevalent within white society during the nineteenth and twentieth centuries. The photographs visually lay claim to and assert dominance over indigenous culture, while at the same time symbolize the desire of white society to domesticate the so-called "savage" Indians in order to make them acceptable in modern society. The Indian image that settler colonialists are emulating in these photographs was primarily what is commonly referred to as the "noble savage," who, as an exemplary "good Indian," was more palatable to society.

Robert F. Berkhofer Jr. provides a comprehensive explanation of the two main, but conflicting, "Indian types" that existed within settler colonial ideology, the "good Indian" and the "bad Indian." The "good Indian" was noble, friendly, hospitable to settlers, handsome and in good physical shape, brave in combat, kind and tender to family and friends and lived a simple and wholesome life that was in tune with nature. ${ }^{15}$ This Indian could also be easily tamed and assimilated, according to settler colonialists. The "bad Indian," however, was seen as savage, lecherous, naked and primitive, sexually promiscuous, warmongering and vengeful against enemies, and were believed to participate in spiritual conjuring, torture, cannibalism, and slavery. ${ }^{16}$ The Indian type depicted in the photographs discussed in this thesis is, in most cases, a representation of the "good" and "natural" Indian to which Berkhofer refers. Philip Deloria

15 Berkhofer, The White Man's Indian, 28.

${ }^{16}$ Ibid, 28. 
acknowledges these Indian types that Berkhofer alludes to and furthers this argument by stating that the images of the "good" and "bad" Indian in fact say more about the people who created them (in this case white, settler colonialists) than they do about actual Native peoples and their cultures. ${ }^{17}$ The "good Indian" was also an ideal figure to emulate, as it was the good Indian who welcomed settlers and "recognized the inevitability of white conquest," in so doing diminishing the enduring guilt that these settlers may have felt about the displacement of Native inhabitants. ${ }^{18}$

The Notman Photographic Archive at the McCord museum is extensive; it contains approximately six hundred thousand photographs, two hundred thousand glass plate negatives and some equipment used in the Notman studios. Fortunately, as a detail-oriented businessman, Notman developed a commercial cataloguing system, which has made it easier for researchers to match prints with corresponding negatives. Studying and understanding this system alone has yielded insights about Notman and how he ran his business. Each glass plate corresponds with a print that is listed and classified in numerical order, where the sitter is also identified; these prints, existing in either cabinet card, or carte-de-visite format, are held in two hundred albums, which are now very fragile. There are forty-three additional albums where the prints are listed in alphabetical order. However, there are also stereocard views and $8 \times 10$ prints that are not part of this album system, many of which have not been digitized, catalogued, or made available on microfilm. According to archivist Nora Hague, who has worked with the collection for many years, the numbering system for the glass plate negatives began in 1861 and continued through to 1936, after which, glass plates were no longer used by the studio. ${ }^{19}$ The museum has had a limited budget for digitization projects and, as a result, only certain date ranges have been digitized and made available online, as well as specific areas of interest. There are, however, 68 reels of microfilm available for the 243 albums. In order to find as many examples as possible of portraits

\footnotetext{
17 Deloria, Playing Indian, 20.

18 Elizabeth S. Bird, ed., Dressing in Feathers: The Construction of the Indian in American Popular Culture (Boulder: Westview Press, 1996), 2.

${ }^{19}$ Conversation between author and Nor Hague, McCord Museum.
} 
of subjects in Native costume, the approach I used during research appointments in the archive was to omit the date ranges I was told had been digitized and look only at the reels of albums that had not yet been digitized. In general, the information on what has been catalogued, digitized, or available on microfilm is not organized into a single document and there are prints in the collection that have not yet been catalogued and were never available on microfilm, making it difficult to say with certainty the number of relevant examples in the collection. Given this, the description and analysis of these portraits consists of what was accessible, and could be easily found in the collection and narrowed down to a selection for the purposes of this thesis. In order to elaborate on the cultural significance of these portraits and relate them to the larger theoretical framework of playing Indian, in the time during which they were made, it was essential to consider all the examples in the collection and attempt to determine the connection between the subject and the costume, how authentic the costumes were and what common tropes could be visually identified. The difficulty in this was access to the examples in the archive and the challenge of working with a collection that has been only partially researched, catalogued and digitized, in addition to not being able to view any of the original prints.

In the Notman studio, the "Indian costume" functions as a means for white settler colonialists to tame the "savage" Indians by appropriating their culture, symbolically asserting their conquest over nature and territory. That these portraits feature men is also significant, for gender is an integral component of playing Indian. Notman's subjects asserted their masculinity visually, by emulating the figure of so-called noble savages - who, in addition to projecting the admirable qualities of the "good Indian," are often stereotyped as strong, powerful hunters.

Settler colonial ideology is again visually represented in photographs of children playing Indian in the AMC Toronto's collection. The AMC is a private archive, with an increasing emphasis on First Nations content that has come from a number of sources acquired over many years. The archive comprises a variety of works of art and cultural objects and also includes a large photography and photographic object collection, which focuses heavily on Canadian 
content. The collection of First Nations material is extensive. I spent a great deal of time exploring the material in the collection before finding these photographs, which had been grouped together based on how they were acquired.

The selection of photographs from the AMC First Nations collection provide a general survey of the various contexts under which playing Indian occurred in Europe, Canada and the United States during the nineteenth and twentieth centuries. These photographs include studio portraits, snapshots of people in costume, snapshots and stereocards of children playing cowboys and Indians, children playing Indian at summer camps, postcards, Hollywood actors, and both Native and non-Native peoples participating in re-enactments. The photographs represent a variety of mediums: albumen and silver gelatin prints, ambrotypes, daguerreotypes, cyanotypes and platinum prints. Other, individual examples of subjects dressed in Native costumes also exist in the form of ambrotypes and daguerreotypes, which were not grouped together under the same inventory numbers. Most of the photographs and objects in this grouping have little to no information, as most have not been individually researched, or catalogued, but some have inscriptions and detail on the recto and verso. In contrast to the Notman studios, which focused mainly on the bolstering of white settler masculinity through the emulation of the "noble savage," the AMC collection centers on the relationship between children and Indians. By examining a selection of representative photographs from the AMC collection, I consider how playing Indian among children served as a means of teaching young Canadians how to lay claim to a national identity.

John Harvey, in his book Men in Black, traces the history of the colour black in fashion and its relationship to society, politics, religion, psychology and power, and looks specifically at how black became the predominant "colour" in fashion during the nineteenth century and, specifically among men, represented a sense of dominance and masculinity. A similar assumption could be made of the Indian costume, not that it became a predominant fashion, but moreover that the Indian costume should be understood as more than simply a costume that was worn for fancy 
dress; the costume had serious cultural implications and embodies, as we will see in this thesis, settler colonial power and dominance over Native peoples and their land, as well as both a masculinity and sense of nationalism bolstered by wearing it and acting out "Indianness." Harvey decisively notes:

That meaning in dress is made of movement in history is apparent in the process that has come to be called power-dressing - as when anyone not in a governing group chooses to wear the clothes the governing group has long worn. At issue here are the more intimate, and more potent, aspects of dress. For while dress may shield a private vulnerability, there are also ways in which, in choosing to wear certain clothes, one may be not so much adopting a cover, as conjuring a new persona for oneself. ${ }^{20}$

The governing group prior to the arrival of settler colonialists were, in fact, the Native peoples of the continent. The new governing group, the settler colonialists, appropriated and dressed up in the traditional clothing of the colonized as a costume, which can be understood as an assertion of their new position of power. The reverse is equally important, as Native peoples also ended up adopting the clothing (although not always by choice) of the new governing group, or combined elements of this dress with their traditional attire.

\footnotetext{
${ }^{20}$ John Harvey, Men in Black (Chicago: University of Chicago Press, 1995), 14.
} 


\section{Methodology and Notes}

This thesis will explore the themes of masculinity, nation-building, "Canadianness," and childhood in relation to indigeneity by situating the photographs within their historical and cultural context and subsequently relating them to the already existing theories of "playing Indian." There is substantial literature on the subject of ethnographic and colonial photography and the practice of appropriating the clothing of colonized subjects, particularly in the literature of Orientalism, but there is very little written on this specific sub-genre of playing Indian in photographs. There is, however, extensive scholarship dealing with the general subject of playing Indian, the appropriation of Native North American culture, as well as the constructed image of the Indian as it relates to stereotypes and identity. By placing these images within an already existing discourse on the subject of playing Indian, this survey of literature will help develop a context in which these photographs can be understood and support my argument that they are, essentially, a direct visual representation of the colonization and subjugation of Native peoples and trivialization of their culture.

In the first chapter, I will begin with a brief description of William Notman and the Notman Studio, followed by a discussion of the collection, my research, and findings. Following that will be a descriptive analysis of select photographs found in the Notman collection and relevant historical and cultural context; I will also elaborate on identifiable tropes found in these studio portraits and how they generally relate to the attitudes of Canadians towards the aboriginal peoples of Canada during that time. The first chapter will conclude by looking at how, overall, the studio portraits in the collection relate to the existing discourse on playing Indian. The second chapter will further this inquiry by looking at examples of children playing Indian found in the AMC collection. Whereas the Notman studio portraits mainly feature grown men playing Indian, the AMC photographs bring to light the importance of male and female children to this practice. In my discussion of the significance of the discourse of childhood for the representation of playing Indian in photography, I argue that these images establish an analogy between the two 
figures, the child and the Indian. Indians were commonly perceived as childlike, existing in a premodern state. ${ }^{21}$ White children were likewise in an early stage of development, but unlike the Indians they are photographed emulating, these white children could be civilized. Such photographs thus project a nostalgic fantasy of pre-modernity.

In relationship to methodology and reading and understanding these images, I would like, for a moment, to look at Roland Barthes and his writing in The Fashion System, wherein he focuses on the fashion industry and the importance of both images and words to market fashion. Barthes outlines in his analysis the importance of words or text that accompany images (photographs), which serve to enhance the knowledge obtained by looking at an image and, simultaneously, reduce its subjectivity. Barthes states that an image inevitably involves several levels of perception, and that the reader of images, although he may not be aware of this, has at his disposal a certain amount of freedom in his choice of perception - the meaning of an image is thus never certain. ${ }^{22}$ Barthes furthers this by saying that this uncertainty can be resolved by the use of words, or text, to accompany an image:

Thus, every written word has a function of authority insofar as it chooses - by proxy, so to speak - instead of the eye. The image freezes an endless number of possibilities; words determine a single certainty...Language makes it possible to deliver information which photography delivers poorly or not at all: the colour of a fabric (if the photograph is black and white), the nature of a detail inaccessible to view (decorative button, pearl stitch), the existence of an element hidden because of the two-dimensional character of the image (the back of a garment); in a general way, what language adds to the image is knowledge. ${ }^{23}$

In my analysis of these images, I have, in a sense, attempted to do what Barthes has described.

This is not to say that these images cannot stand alone, nor is it to say that they are not powerful without text, but in order to fully understand their cultural significance, placing them in both

\footnotetext{
${ }^{21}$ Deloria, Playing Indian, 106.

${ }^{22}$ Roland Barthes, The Fashion System (Berkeley and Los Angeles: University of California Press Ltd., 1990), 14-15.

${ }^{23}$ Ibid, , 14-15.
} 
historical and literary contexts has served to enhance their meaning and add, as Barthes states, knowledge to the images, which will ultimately influence how they are viewed and understood. 


\section{Chapter 1: Native North American Costumes in the Notman Photographic Archives}

\section{Context}

In William Notman's renowned Skating Carnival composite, made in 1870, numerous subjects appear dressed in costume (fig. 7). In the bottom corner on the viewer's right is Mr. Reynolds, dressed up in a native North American costume with a bow and arrow, as "Quewaygoosquequamteros" (fig. 8). Mr. Reynolds recently got some attention, as his photograph, originally taken for the composite, was featured among others from the collection in visual artist Kent Monkman's piece Welcome to the Studio: An Allegory for Artistic Reflection and Transformation (fig. 9). ${ }^{24}$ Monkman's painting references the composite technique for which

\footnotetext{
${ }^{24}$ After seeing Kent Monkman's painting Welcome to the Studio: An Allegory for Artistic Reflection and Transformation exhibited at the museum, which included several figures dressed in Native costumes, based on individual portraits originally made by the Notman studio, I realized that these photographs had, in some way, already been addressed. The portrait of Mr. Reynolds posed with "a friend," was one of thirty photographs used from the Notman Photographic Archive at the McCord museum in Monkman's painting; a piece completed in 2013, as part of the museum's artist in residence program (fig. 9). The piece is a direct reference to French painter Gustave Courbet's work The Painter's Studio, dealing with the intersection of photography and painting and the influence the new medium had on artistic practice. Monkman in an interview about his work notes the following:

'I remembered Gustave Courbet's painting of his own studio L'Atelier du peintre/The Painter's Studio, 1855 , and I decided to make a painting that would respond to that. Courbet was painting at the time when photography was emerging as a new medium. It was a self-portrait, as well as a multiple portrait of many people from various aspects of his world. I wanted to create a similar painting that would reflect Notman's studio, with many of the different characters from Montreal society that he photographed there."

Monkman's piece makes reference to art history, but is also a commentary, as with most of his work, on the colonial experience, the representation of Native peoples and Canadian identity. An interesting comparison is drawn between the realist movement in painting, to which Courbet belonged, and the idea of truth in photography. The realist movement in painting, originating in Britain and France during the mid-nineteenth century, was based on a truthful and objective representation of everyday life and one's surroundings, society and politics. Monkman's painting, however, is a completely fictional composite, made up of subjects from Notman's studio portraits, where the individual characters are posed and interacting differently than they are in the original portraits. Going back to the idea of identity and Native representation, several of the subjects featured in Monkman's painting are dressed up in Native costumes and are in fact "playing Indian," while posing in the studio; the photographs themselves are the opposite of a truthful and objective representation, one of the political undertones of Monkman's piece. Sarah Milroy, a Canadian journalist and art critic discusses this political undertone in her article Historic Drag, written for the May 2014 issue of Walrus Magazine, in response to Monkman's exhibition at the McCord Museum. While addressing the relationship between the portraits made by Notman of subjects dressed in "Indian costumes" and the fancy dress balls they attended, Milroy points out the irony of settler colonialists appreciating Indigenous cultures, while simultaneously being responsible for their demise: "Consider, as Monkman has, the portrait collection of wealthy Montrealers dressed for the Château de Ramezay Ball of 1898, which drew together the members of high society in support of the Women's
} 
Notman became renowned: on a very basic level, taking multiple images and combining them into one completely contrived piece. The Skating Carnival at the Victoria Rink was Notman's first successful composite, after which the composite photograph became a standard service offered by the studio. ${ }^{25}$ The composite photographs made by the Notman studio involved a complex process and employed a number of staff and studio assistants; these were reproduced at various sizes and sold commercially. ${ }^{26}$ Although my intent is not to focus specifically on Notman and his photographic techniques, a brief account of Notman's history, his studios and commercial practice provides necessary context for understanding one of the most interesting features of this photograph, not to mention the studio's larger body of work, namely the representation of playing Indian. What are the main visual tropes of playing Indian and what significance might these tropes have for Montreal society, whose members posed for and would likely have seen these portraits? These are the key questions that this chapter considers.

William Notman is an internationally recognized entrepreneur and commercial photographer who built his career in Montreal after emigrating from Glasgow, Scotland, in $1856 .^{27}$ Notman, apparently, had no previous experience as a professional photographer in Europe, but some evidence suggests that he may have been an amateur practitioner before moving to Canada. ${ }^{28}$ Notman's successful career as a photographer and businessman spanned over thirty-five years; he expanded beyond his studio in Montreal and opened studios in other Canadian cities such as Toronto, Ottawa, Halifax and St. John, eventually opening one in Boston in $1877 .{ }^{29}$ Notman also employed many staff members, both men and women, who helped with all aspects of the business, from bookkeepers and artists to studio assistants and dressing room

\footnotetext{
Antiquarian Society. Guests were invited to take their pick of costume categories - from habitants and coureurs de bois to British officers and, of course, Indians. (Then, as now, settler culture made a point of "celebrating" Indigenous society at the very moment when it was being effaced.)"

${ }^{25}$ Stanley G. Triggs, The Composite Photograph, McCord Museum of Canadian History, 2005.

26 Ibid.

${ }^{27}$ Sarah Parsons, William Notman: Life \& Work (Toronto: The Art Institute, 2014), 4-5.

${ }^{28}$ Ibid, 4-5.

${ }^{29}$ Stanley G, Triggs, The Man and the Studio, McCord Museum of Canadian History, 2005.
} 
attendants. ${ }^{30}$ The studio assistants and dressing room attendants would have helped to stage the dress in portraits and thus played a key role in helping subjects transform, or enhance their identities, within the studio. Since Notman also employed other photographers, it has been a challenge for researchers and academics working with the archive to determine, with certainty, which photographs were taken by Notman himself, and which by one of his staff photographers, unless it was directly indicated on the negative. An obvious assumption has been made that many of the early portraits were taken by Notman, as he did not yet have a full staff, and that later on in his career, Notman led more complex projects and only took photographs of royalty, politicians, celebrities and dignitaries. ${ }^{31}$

The Notman studio also received several commissions to photograph various views, towns, landscapes, urban and industrial expansion, trades, and construction of the railway. After documenting the construction of the Victoria Bridge, Notman was commissioned to photograph the construction of the Grand Trunk Railway, among others, and produced views of farms and settlements along the railway lines as areas were being developed. ${ }^{32}$ The Notman studio's largest commission, however, was for the Canadian Pacific Railway, a transcontinental line that was built from Montreal, across the West, to the Pacific Ocean. Notman supplied a large collection of photographs to the Canadian Pacific Railway for promotional use in exchange for being able to keep the original negatives and the copyright, which allowed the Notman studio to later reproduce the images for commercial purposes. ${ }^{33}$ Notman's son, William McFarlane Notman, made several trips along the Canadian Pacific Railway between 1884 and 1909, photographing scenic western views, Native peoples and various settlements along the line (fig. 10). ${ }^{34}$ The Notman studio, among other photographic studios, contributed to what became a successful promotional campaign for the CPR during the late nineteenth century, as many of the

\footnotetext{
${ }^{30}$ Parsons, William Notman: Life \& Work, 4-5.

31 Ibid., 38-39.

32 Triggs, The Man and the Studio, 16.

33 Ibid.

${ }^{34}$ Ibid.
} 
photographs taken ended up on postcards, advertising and promotional material and also served as mementos for tourists. Many of these images produced and sold were of Native peoples and, as Daniel Francis points out, the railway used the image of the Indian to market its services to travellers. Native peoples became popular tourist attractions along the railway line. ${ }^{35}$ The railway also played a significant role in the development of Canada as a nation, united from East to West.

Another noteworthy relationship exists between the notion of masculinity and the development of the Canadian railway. Francis Margot again points out that railway technology played a key role in the very male dominated activity of nation building and that the "speed, power, size and control symbolized by this transportation revolution were important signifiers in an implicitly masculinist national trajectory." 36 The power and technology of the railway became an important symbol of masculinity's conquest of nature and the territory in Canada. ${ }^{37}$ The theme of masculinity can be deciphered in photography, as I explain below, in Notman's studio portraits. In the photographs that I examine, significantly, grown men are the ones who played Indian. This depiction bolstered their masculinity, for the "noble savage" was seen as strong, virile, proficient at hunting and warfare, a man of nature and a skilled outdoorsman; as such, this figure was likely an appealing model of masculinity for white settler colonials to emulate.

Equally relevant information regarding Notman and his studio enterprise is how the studio facilitated the act of dressing-up to have one's portrait taken, using elaborate sets and backdrops. Notman also had an experimental space that he and his staff used to create their own worlds, where people could transform their identities and become whomever they wanted,

35 According to Francis Margot, the legacy of the Canadian Pacific Railway was a "foundational image in Canadian nation building, starting with the photographs, posters, and testimonials distributed by the CPR, encouraging European settlers to undertake en epic journey to a new homeland." The image of the Indian was widely circulated due to the construction of railway lines and photographers such as Notman, who brought these images back to Eastern Canada. There is a strong relationship between the image of the Indian and the idea of "Canadianness" via the exposure that tourists and travellers had to Native peoples, because of the railway. The image of the Indian thus became a key component in the formation of Canadian identity by means of travel and tourism. Significantly, the development of the Canadian railway was a markedly masculine enterprise.

${ }^{36}$ Margot Francis. Creative Subversions: Whiteness, Indigeneity, and the National Imaginary (Vancouver: UBC Press, 2011), 62.

${ }^{37}$ Ibid., 60. 
wherever they wanted. ${ }^{38}$ Sarah Parsons in her e-book William Notman: Life \& Work, published for the Art Canada Institute, refers to Notman as an innovator in genre photography, constructing scenes and creating other realities in the studio.

It has already been established that most of the subjects dressed in Native costumes and photographed at the Notman studio were, as Cynthia Cooper mentions, doing so because they were either attending a fancy dress ball, reserved for the elite who could afford such entertainments, or going to skating carnivals, where the Indian costume was a popular choice. ${ }^{39}$ Several of the examples in the collection of subjects dressed in skating carnival costumes were made in 1870 , when the first skating carnival composite was made (fig.11 and fig. 12). As a recognizable aspect of the nature of Canada, such skating scenes illustrate a national part of life. On February 25, 1870, an ad appeared in the Montreal Gazette inviting those attending the skating carnival at the Victoria Rink, which Prince Arthur was expected to attend, to come to Notman's studio with skates and costumes for a portrait session prior to the carnival; these individual portraits were then included in the composite. ${ }^{40}$ Winter sports such as skating were just one of the ways that a quintessentially Canadian scene was set. Indeed, the portraits helped bring into focus a Canadian — and masculine — sense of identity through the construction of visual tropes of indigeneity.

This chapter explores the significance of the most pronounced of these tropes, Plains Indian costuming, winter sets, and sports like skating and lacrosse. Through a consideration of these visual tropes, I explore how Notman's photographs reflected settler colonial assumptions about Indian stereotypes, and consider the cultural function of these stereotypes, especially for the Montreal men who seemed most drawn to the practice of playing Indian.

\footnotetext{
${ }^{38}$ Parsons, William Notman: Life \& Work, 16-17.

${ }^{39}$ Cooper, Magnificent Entertainments, 22.

40 Triggs, The Composite Photograph, 4-5.
} 


\section{Discussion of Examples Found in the Collection}

\section{Indian Costumes in the Notman Studio}

Victorians were enthusiastic about dressing up for a variety of social occasions. Dressing up for balls and parties became increasingly popular throughout the nineteenth century, reaching its peak during the last quarter of the century not only in Britain, but also across Europe and North America. ${ }^{41}$ Having the right costume for such an event was quite important and, as with most social events in Victorian culture, equally important were etiquette and social conventions. In the introduction of a book titled Masquerade and Carnival: Their Customs and Costumes, published in 1892 by The Butterick Publishing Company in London (fig. 13), the author guarantees that, "everyone may herein find a suitable costume for any festivity or entertainment requiring Fancy Dress, and reliable decisions as to the different codes of etiquette governing such revelries." ${ }^{42}$ A section is included on how to dress up in costumes of other cultures and next to the "Oriental" and "East Indian Costume" are "The North American Indian" and "Pocahontas" (fig. 14 and fig. 15). According to the guidelines, the key elements of The North American Indian costume are as follows: a worn looking coat and pants, beadwork on the coat, brass armlets and a necklace of wolf's teeth. A waist belt and sash are to be used to hold the tomahawk and scalping knife. In addition, a long black wig, an Indian headdress of feathers, and leather moccasins are to be worn and a bow and arrow carried to complete the outfit. The most significant aspect of the description is the advice for revellers to don redface: "the face [should] be stained a reddishbrown, or copper colour; and in addition the eye-brows may be blackened to meet at the center, and the face may be painted beneath the lower eyelids to produce a properly savage expression." ${ }^{\text {43 }}$ The Pocahontas costume is marketed as a "pretty costume for a dark brunette." For

\footnotetext{
${ }^{41}$ Cooper, Magnificent Entertainments, 15.

${ }^{42}$ Masquerade and Carnival (London and New York: The Butterick Publishing Co. Limited, 1892), Introduction.

${ }^{43}$ Ibid., 39.
} 
the Pocahontas costume, one would need "smooth woollen goods of light leather colour" to mimic hide and feathers, beads, coloured fabrics and embroidery to decorate the material. Fringe is included on the skirt, a wolf skin should hang from the shoulders and a beaded pouch hangs from the belt. One should also adorn oneself in beads and animal teeth and, according to the illustration provided, the hair is braided and then fashioned with a headband and feather. As with the male version of the costume, beaded moccasins, a bow and arrow and a tomahawk should also be included. The costume descriptions exemplify many of the common tropes associated with the stereotypical image of the Indian during that time. It demonstrates a complete disregard for the numerous individual cultures and defines all Native North Americans by a single pan-Indian image, not to mention the overt racism in the sentence on how to create a "properly savage expression" via the application of makeup.

Cynthia Cooper addresses the relationship between the choice to wear an Indian costume for fancy dress and the existing and broadly accepted stereotypes which represented the attitudes Victorian Canadians had towards the aboriginal peoples of Canada during that time. Cooper writes that fancy dress balls included costumes and characters from various aspects of history, literature and Victorian life, but notes that fancy dress often "conformed to prevailing

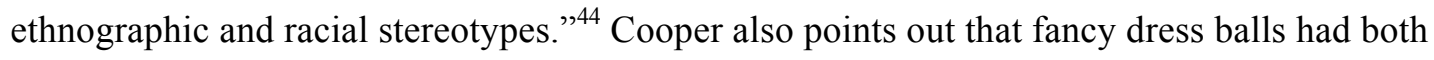
political and social agendas and were a means for those in the upper echelons of society and politics to reinforce and shape Canadian identity, which in certain cases included the promotion of Canadian nationalism. ${ }^{45}$ Organized by a women's branch of the Antiquarian Society, the Historical Fancy Dress Ball reflected the collective desire of Montrealers for preserving local history and, more generally, a nation-wide interest in Canadian history; this was closely tied to a drive during the late nineteenth century to establish a sense of nationalism and identity in

\footnotetext{
${ }^{44}$ Cooper, Magnificent Entertainments, 35.

${ }^{45}$ Ibid., 15.
} 
Canada. ${ }^{46}$ The ball was intended to raise funds to aid in the maintenance of the eighteenth century Chateau de Ramezay and was supported by the Governor General and his wife, Lady Aberdeen, known herself for throwing prestigious fancy dress balls. ${ }^{47}$ A brochure was distributed to those invited to the ball, with a small section dedicated to costumes, indicating which costumes were appropriate for the occasion (fig. 16). The overall concept of the ball was to have guests dressed in costumes that reflected the history of the Chateau between the years 1705 and 1820, and clearly states that, "later costumes which approximate to modern are not recommended." 48 The statement is then followed by a list of recommended historical costumes, one of the categories being Canadian (fig. 17). Notably, under the Canadian category are the following options: "Indian, Trapper or Voyageur, Peasant." ${ }^{49}$ The ball was not only a fundraiser, but had a very specific agenda, as the pamphlet states, "The Ball has been designed with a hope of creating, in the citizens of Montreal, a personal interest in their valuable legacy." It is evident that the ball was also intended to contribute to the far greater goal of reinforcing national identity and the history and heritage of Montreal. As we see in the list of costume suggestions, the Indian was seen as a distinctive Canadian type; playing Indian enabled settler colonials to establish an autochthonous claim to the Canadian land. In short, the figure of the Indian was considered a key component of this national heritage.

Montrealers who came to the Notman Studio played dress-up by donning indigenous clothing and props, but these costumes were not always accurate. Rather, at times, they combined different nations, and more often referenced, as I show below, Plains Indian dress. Yet Plains Indians were not indigenous to Montreal. The aboriginal peoples of Quebec include primarily the Algonquian and Iroquoian First Nations communities, the Inuit in the North and the Micmac, who are autochthonous to the Gaspé peninsula in Quebec and the Atlantic provinces. During the time

\footnotetext{
${ }^{46}$ Ibid., 131.

${ }^{47}$ Ibid., 131-132.

${ }^{48}$ Historical Costume Reception and Ball Invitation

${ }^{49}$ Ibid.
} 
these portraits were made, the closest nations to Montreal would have been those belonging to the Iroquoian confederacy, such as the Mohawk communities of Akwesasne and Khanawake.

Although the Mohawk dress, at one point, traditionally included deerskins, they did not have the heavy fringe associated with the Plains cultures. Before European contact the Iroquois, in general, often painted and dyed geometric patterns onto hide and also used porcupine quillwork for decoration. ${ }^{50}$ Face and body tattooing was also common and, after the fur trade, the Iroquois became proficient silversmiths, making adornments such as earrings, armbands and nose rings, which replaced the previous accessories made of shells. ${ }^{51}$ Mohawk men did not often wear elaborate headdresses, nor did the women. It was common, however, for men to only have a small section of long hair at the crown of the head, which would then be braided. After contact, the Mohawk combined their traditional way of dress with materials obtained through trade and therefore, during this time, would have had clothing made from a combination of animal hide, cloth and commercially dyed wool. ${ }^{52}$ The Mohawk also eventually wore what came to be known as the ribbon shirt by the late nineteenth century.

However, the Plains nations within Canada were mainly located in what became the provinces of Manitoba, Saskatchewan and Alberta. The true "Plains Indian," could not be found in Quebec, so Montreal was a stretch. There is some representation of the Micmac culture within the Notman portraits, as seen in figure 12, a portrait of James Fletcher as "Che-oc-che-moo-che," or "White Maple Leaf, the Micmac." I am not certain whether the name is fake, or if the English translation of the name is accurate, but that is the name provided in the image description. Although Fletcher's costume appears to include a mix of cultural elements, the cloth, or possibly woollen coat he is wearing is consistent with the long, ornately decorated coats worn by the Micmac after trade with Europeans. There do appear to be some recognizable elements of these

\footnotetext{
50 Brasser, Native American Clothing: An Illustrated History (Buffalo, New York and Richmond Hill, Ontario: Firefly Books Ltd., 2009), 62-76.

51 Ibid., 62-67.

52 Brasser, Native American Clothing, 71.
} 
local cultures within some of the costumes in Notman Studio portraits, but the majority of the costumes are a melange of elements from various tribes, making it difficult to say with any certainty that the subjects were attempting to represent a specific culture. This discrepancy in the studio portraits suggests that Montreal society disregarded the nuances of Indian cultures, and that the practice of playing Indian illustrated a fantasy about appropriating these cultures rather than a desire to learn more about them.

Scholars agree that the most common indigenous costume elements in visual culture are associated with the Plains Indian, who came to represent the ideal or rather stereotypical Indian. For example, John C. Ewers, an ethnologist, museum curator and specialist on Plains cultures who worked for the Smithsonian Institute, published an article in 1964 titled "The Emergence of the Plains Indian as the Symbol of the North American Indian." In this article, Ewers traces the development of this image of the Plains Indian from its inception onward throughout the nineteenth century via art, literature, historical accounts, the illustrated news, dime novels and the Buffalo Bill Wild West show, noting that it is a prolonged process that involves multiple factors. He begins with the earliest artistic portraits and silhouettes made of the Plains tribes delegations that visited Washington during the first decade of the nineteenth century, by artists Charles Balthazar Fevret de Saint-Mémin from France and Philadelphia artist Charles Willson Peale, and another set of paintings made in 1821 of a delegation of Plains tribes from the Lower Missouri and Platte Valley region, painted by Charles Bird King. ${ }^{53}$ Ewers explains that the diffusion of copies of these paintings made by King in Europe, and their inclusion in the National Indian Portrait Gallery in Washington, brought these images to a greater audience. ${ }^{54}$ During this time, artists such as John Neagle, Charles Bird King and Samuel F.B. Morse all made portraits of the famous Pawnee warrior Petalesharro wearing a long feather headdress, which, according to Ewers, was the "first of the millions of pictorial renderings of this picturesque Indian headgear

53 John Canfield Ewers, "The Emergence of the Plains Indian as the Symbol of the North American Indian," in Indian Life on the Upper Missouri (Oklahoma: University of Oklahoma Press, 1968), 188-189. ${ }^{54}$ Ibid., 189. 
produced by artists and photographers." ${ }^{, 55}$ Ewers goes on to mention the influence that the writing and paintings of American artists such as George Catlin and Canadian artist Paul Kane, among other European painters, had on the pictorial representations of the Plains cultures. Another interesting point Ewers makes is how popular histories of the Indian wars, published during the 1850s, often erroneously applied elements of Plains cultures to Eastern Woodlands tribes. Ewers concludes the article by illustrating how influential the Buffalo Bill Wild West Show was in solidifying the Plains image in both Europe and North America during the later part of the nineteenth and early twentieth centuries, and states that during the nineteenth century, the warbonneted Plains Indian emerged as the widely recognized symbol of the North American Indian. ${ }^{56}$ This oversimplification of the many aboriginal nations and tribes in both Canada and the United States is, as Daniel Francis states, due in part to the exposure people had to these cultures via imagery, literature and entertainment like the Buffalo Bill Wild West Show. ${ }^{57}$ The image was a product of the visual culture shaped by settler colonial ideology. Francis suggests that what he calls the "Imaginary Indian," was influenced by how artists, photographers and writers chose to portray Native peoples throughout the eighteenth and nineteenth centuries. ${ }^{58}$ One would think that this singular image of the "Indian" Francis refers to began to shift throughout the late nineteenth and early twentieth centuries, as photographers set out to document the different Native cultures throughout North America, concerned that they were all "vanishing." It seems, however, that this image of the Indian inspired by the Plains cultures prevailed as the dominant and stereotypical image after which those playing Indian modeled their costumes well into the twentieth century.

As mentioned earlier, examples of these Plains-inspired costumes exist in both simplified and elaborate forms in the Notman collection, as seen again when we compare the portrait of Charles Bouthillier taken in 1865 and Mr. Wright and F.A. Wise in 1881 (figures 18, 19, and 20).

\footnotetext{
${ }^{55}$ Ibid., 190.

${ }^{56}$ Ewers, "The Emergence of the Plains Indian as the Symbol of the North American Indian," 203.

${ }^{57}$ Francis, The Imaginary Indian, 106.

${ }^{58}$ Ibid., 57.
} 
Although it was common to paint geometric patterns and designs onto hide, or cloth, ${ }^{59}$ looking very closely at the costumes of Wright and Wise, these decorative and patterned panels could actually be inauthentic, but this would require seeing the actual costumes in person. In traditional Plains cultures, these designs would more likely have been made with intricate porcupine quillwork and later on, after contact, with beads obtained through trade; the embellishments on their costumes look more like cloth sewn together like a quilt. F.A. Wise and Mr. Wright do, however, appear to be wearing the same costume.

Elements of the Plains style can be seen in other Notman photographs. Take, for example, one of the earliest examples found in the collection, dated 1862 (fig. 21), which portrays Charles Adolphus Murray, or Lord Dunmore the $7^{\text {th }}$ Earl of Dunmore. Dunmore kneels with a bow and arrow held over his left knee, and is likely meant to be a hunter. Overall, the mood of the image seems almost pictorialist, with its emphasis on beauty, and its painterly quality; the softness of the details and the fact that the photograph has been hand-painted contribute to this pictorial effect (pictorialists in photography aimed to replicate a painterly aesthetic), which seems contrived rather than realistic. The pose is majestic and graceful, while simultaneously evoking a strong sense of masculinity. The subject is set against an ambiguous landscape, which works to emphasize the subject, his costume and foreground props. Since the photograph has been painted and the details are quite soft, it is difficult to determine whether the attire contains any decorative porcupine quillwork, or beading and whether it is made of authentic materials. The heavy fringe on the leggings, pouch and shirt suggest that the costume is intended to mimic the dress of traditional Plains cultures; this would be fitting, as the Plains cultures were known for their hunting skills, specifically buffalo hunting, although realistically by the time this portrait was made, the bow and arrow (props in the costume) would have been replaced by a gun. Traditionally, this type of attire would have been made of deerskin, or buffalo, and in some cases moose and antelope hides were also used. It is impossible, however, to specify which Plains

\footnotetext{
${ }^{59}$ Brasser, Native American Clothing, 63-76.
} 
culture, as not enough detail can be seen in the print. Although the different Plains cultures dressed similarly and hybrid designs existed, due to trading, gift-giving and intertribal communication, the clothing differed according to nation and traditions. ${ }^{60}$ The costume worn by the subject appears generic and the fact that no specific cultural distinction can be made is not surprising, as it includes all the familiar and identifiable stereotypes needed to make him an "Indian:" fringe leggings and shirt, bow and arrow, hunting pouch, and the symbolism of the arrows arranged in the form of a tepee. These stereotypes of Indianness found in Lord Dunmore's portrait are present throughout many of the other examples found in the Notman collection. The ambiguity of the costume suggests an indifference to the numerous aboriginal cultures in Canada, as it defines all Native peoples by a single image that was in keeping with settler colonial ideology's reduction of these peoples to a stereotype.

In figure 22, which is dated 1863 , Mr. Jefferson, of the $16^{\text {th }}$ Regiment, appears to be crossdressing, wearing a traditional women's dress and a dark, rather dishevelled, longhaired wig. Heavy fringe and porcupine quillwork can be identified again, likely from, or meant to imitate, the Plains traditions. The portrait of Mr. Jefferson does not seem to be as carefully composed as that of the $7^{\text {th }}$ Earl of Dunmore; the subject is not gracefully posed and his facial expression and overall body language are not as aesthetically pleasing as those of Dunmore. The architectural background does not fit the costume and the ornate plant stand seems out of place. It looks as though either his awkward endeavour to be more feminine failed, or that he was attempting to be "in character," as he is facing the camera directly, his arms are folded, his pose almost mocking and not very elegant. No concrete claim can be maintained as to why Mr. Jefferson would have chosen what looks to be a traditional women's dress, but the fact that he is cross-dressing is intriguing, compared to all of the other portraits of men in costume, which are by contrast, quite masculine; Jefferson thus did not seem pre-occupied with portraying the virile version of

\footnotetext{
${ }^{60}$ Josephine Paterek, Encyclopedia of American Indian Costume (Santa Barbara: ABCCLIO, Inc., 1994), 84.
} 
Indianness, which I will explore further in this chapter. I have observed, by looking at various examples of both Native and non-Native peoples in costume posed in photographs, that the stance of front-folded arms with the subject upright and directly facing the camera seems to be a stereotype commonly associated with Native peoples, as seen again in this snapshot of a man dressed in costume, also in character (fig.23).

Likewise, in figure 24, a long feathered headdress can be seen, just as this one worn by Mr. Bourdon (fig. 25) in one of the Notman portraits. The caption given to this photograph in the Notman album is Mr. Bourdon as Indian Chief and in brackets below it reads "Black Feet;" the subject obviously meant to be dressed as a Blackfoot chief. The iconic, halo war bonnet worn by Mr. Bourdon in this photograph, however, was not commonly worn by the Blackfoot, who instead traditionally wore the straight-up war bonnet. In these other two photographs of the same subject, the caption also reads Mr. Bourdon as Indian Chief, but below in quotations appears to say "Kingtail," likely a fictional name (fig. 26). The set of two portraits of Bourdon are reminiscent of the photograph discussed earlier of Lord Dunmore kneeling, holding a bow and arrow. In these examples face paint can also be identified. Face and body painting was common practice among Plains cultures. Not just used for personal decoration, face and body painting was often spiritual, ceremonial, or used as a talisman for protection in preparation for war, ${ }^{61}$ but eventually it became a widely used trope in native costuming and playing Indian, completely devoid of its original meaning and cultural significance. The application of "war paint," is often seen on children's faces when they took to playing Indian, as I discuss in the second chapter (fig. 27).

Similarly, Andrew M. McCulloch, first photographed by the Notman studio in 1863, appears in Native costume that was an inauthentic rendering of the Plains style of dress; a unique hand-coloured version, painted by John Fraser, also exists in the collection (fig. 28). John Arthur Fraser was a painter from England, hired by Notman in 1860 to head the art department and

\footnotetext{
${ }^{61}$ Paterek, Encyclopedia of American Indian Costume, 87.
} 
artistically hand colour photographs. ${ }^{62}$ McCulloch returned in 1898 to have his portrait taken again, wearing elements of the same costume as the one he wore in 1863 (fig. 29). Although it is difficult to see all of the detail, it is obvious that McCulloch's costume contains elements that are inauthentic, as they look quite cheaply made. These elements include the tomahawk, shirt, headdress and moccasins. Authentic Native dress required craftsmanship and skill, not to mention a great deal of effort and time, whether for everyday wear, ceremony, battle, or regalia. I have observed that "costume," or commercially produced Native dress looks quite cheap, in comparison to authentic pieces. The portrait of McCulloch made in 1898 coincided with the Historical Fancy Dress Ball held on January 18 to honour the Chateau de Ramezay in Montreal, where others in attendance also had their portraits taken in costume at the Notman studio (fig. $30)$.

Figure 31 portrays Henry G. Vennor posed on an arrangement of fur blankets. Likewise, he wears a costume in the traditional Plains style. Porcupine quillwork details can be identified on the clothing and also on the headband of what appears to be a stand-up, feathered war bonnet, although it looks more like a costume headdress. A rather unusual element of Vennor's costume is the large septum ring, which may have been painted on. Traditionally, the septum ring was a small adornment worn by men belonging to the Shawnee, originally an Eastern Woodlands tribe. ${ }^{63}$ The famous Shawnee chief Tecumseh, who was responsible for leading a pan-First Nations confederacy during the late eighteenth century that allied with the British against the Americans in the war of 1812 , also wore a septum ring. ${ }^{64}$ Chief Tecumseh was seen as a strong and powerful leader, fierce and extremely masculine. Popular paintings of Chief Tecumseh also existed, in which he was shown wearing a septum ring; this could have had an influence on Indian costumes in the same way that Ewers describes how early paintings of Native peoples influenced how peoples visualized the Indian. As mentioned earlier, the Iroquois were also

\footnotetext{
${ }^{62}$ Stanley G. Triggs, McCord museum, 1977.

${ }^{63}$ Paterek, Encyclopedia of American Indian Costume, 75.

${ }^{64}$ Ibid., 75 .
} 
known for silver adornments and occasionally men would wear silver septum rings; this would also make sense as a possible explanation for Vennor's septum ring, as Iroquois communities were located in Quebec. In addition, the Eastern Woodlands tribes were known for porcupine quillwork, so it is possible that Vennor's costume combines both Plains and Eastern Woodlands elements.

As this catalogue of costume elements demonstrates, the Notman studio portraits visually bears out Ewers's claim that the stereotypical image of the North American Indian was heavily influenced by the Plains cultures and continued as the prevailing image of the Indian. The signifiers of Indianness found in the Notman portraits, whether in the costumes themselves, the props, or the poses, seem to derive from this pan-Indian image that Ewers references in his argument. The Notman studio was a space for which white settler colonialists could act out this contrived and nostalgic representation of the Indian, not by portraying actual Indians or by conferring agency to Indians, but rather by dressing up in costume and having their portrait taken in what amounts to a false claim of indigeneity. The Indians they were playing, however, could not actually exist in their modern society; Native peoples, during that time, were meant to assimilate, give up their cultural practices and were segregated.

\section{Canadian Themes and National Identity}

Costuming is only one element through which Indian signifiers are illuminated. Setting was another pivotal means through which an indigenous backdrop could be established. Many portraits in the Notman studio collection use what the studio referred to as "winter sets," which can also be interpreted as another visual trope of indigeneity. As mentioned previously, Notman had space in his studio dedicated to building sets and creating intricate scenes in order to bring the Canadian wilderness, landscapes and winter into the studio, as seen in this portrait of a family tobogganing down what is obviously a fake snow bank (fig. 32). Notman's winter sets embody 
what we would now call Canadiana. The function of the winter sets was to not only bring the outdoors indoors, making it easier to take photographs that would have been technically very difficult to accomplish in a real setting, but also to visually represent an element of the Canadian experience in a studio photograph. The harsh Canadian wilderness was, in a sense, tamed by the controlled studio environment where clients could become trappers, hunters, pioneers, or Native peoples, conquering the great outdoors within the safety of the photography studio.

The winter sets brought the Notman studio a great deal of success and recognition. Indeed, Notman's “Caribou Hunting” series won several awards at the Paris World Expo in 1867. ${ }^{65}$ During 1866, William Rhodes, an officer in the British military, commissioned Notman to take a series of portraits of Rhodes hunting caribou in the Canadian wilderness; the wilderness being a series of sets imagined and built by Notman and his staff (fig. 33 and fig. 34). ${ }^{66}$ The “Caribou Hunting” photographs were included in several exhibitions, were published and eventually became very popular images due to their Canadian appeal. ${ }^{67}$ The winter scenes were set against painted backdrops and were constructed using various materials that mimicked snow. Trees and shrubs, among other props, were used to create the illusion of really being outdoors. For the skating photographs, Notman apparently used a highly polished zinc plate, which looked like ice, a possible example being this portrait taken for the skating carnival composite, where the figure appears to be skating on ice (fig. 35) ${ }^{68}$ Looking at these portraits today, within the context of modern photographic technology, the sets look completely fake, but at the time they were considered highly innovative and very realistic. Notman was, therefore, quite the master of illusion and his photography studio became a transformative space where one's identity could easily be changed with a costume and an elaborate setting. In the same manner that the harsh Canadian wilderness could be subdued within the Notman studio setting, the "wild" Indian could

\footnotetext{
65 Parsons, William Notman: Life \& Work, 16-17.

${ }^{66}$ Ibid.

${ }^{67}$ Ibid.

${ }^{68}$ Ibid.
} 
be tamed by white settler colonialists dressing up in Native costumes in front of the portrait lens. When the series of caribou hunting photographs commissioned by Rhodes is examined more closely, one could conclude that the highly staged portraits are an attempt to demonstrate his skill as an outdoorsman and in this way to reinforce his masculinity. In Notman's studio and via the portrait lens, Rhodes was able to conquer the great Canadian wilderness.

It was not just the construction of the railway that was pivotal to this gendered process of taming the land for the purposes of nation-building; other industries, which were tied to the land (as in mining) and with Indian traditions (trapping), can be seen in Notman's photographs to participate in this discursive process. Consider, Henry G. Vennor, whose portrait we looked at earlier, who was a geologist, ornithologist and eventually became a weatherman. ${ }^{69}$ Vennor studied natural sciences at McGill University during the 1850s and during 1865 completed an internship with the Geological Survey of Canada (GSC), where he did survey work on Manitoulin Island, eventually becoming a full member of the team. ${ }^{70}$ It is likely that during this survey work Vennor would have come in contact with the Anishinaabe people of the island, the Ojibwe, Odawa and Potawatomi, which may have contributed to an interest in aboriginal culture. In 1876, Vennor also collaborated with William Notman and published the book Our Birds of Prey, for which Notman provided the photographs. ${ }^{71}$ A natural scientist, Vennor was enthusiastic about nature and spent a lot of time in the outdoors, he may have been interested in the connection that the aboriginal peoples of Canada had with their environment.

The Geological Survey of Canada, which Vennor eventually worked for, played an important role in the establishment of the mineral industry and the exploration of Canada. The original intent of the GSC, founded in 1842, was to find a Canadian supply for coal, due to its importance for industrial and economic growth and to institute a sustainable mineral industry in

${ }^{69}$ P.R. Eakins, "VENNOR, HENRY GEORGE," in Dictionary of Canadian Biography, vol. 11 (University of Toronto/Université Laval, 2003), accessed July 8, 2015, http://www.biographi.ca/en/bio/vennor_henry_george_11E.html.

${ }^{70}$ Ibid.

${ }^{71}$ Ibid. 
Canada. $^{72}$ The GSC was originally based out of Montreal and by the 1850 s the survey was a recognized organization, leading major exploration and cartography projects, and in 1863 published the first book titled Geology of Canada, complete with hand-coloured maps. ${ }^{73}$ After Confederation in 1867, the GSC expanded their territorial explorations to include areas of uncharted land across western Canada and the North, which helped to establish the mining industry in Canada. ${ }^{74}$ Equally important to note is that the organization documented geological resources along the planned transcontinental railway lines during the late nineteenth and early twentieth centuries. During the time that Vennor was working as a geologist for the GSC, geological surveying across Canada played a key role in nation building and the development of a mining and mineral industry in Canada, which conversely led to the displacement of many Native peoples, due to an increasing demand for access to natural resources used for industrial and economic expansion. Against this context, the portrait of the geologist Vennor playing Indianappropriating Indian identity—complicates this history of exploitation.

Although there is no visual evidence of his role as geologist in his studio portrait (fig. 31), Vennor's depiction amongst a backdrop of resplendent furs offers an indirect glimpse at this veiled context of exploration and exploitation. That is, in this portrait, the geologist surrounds himself with furs that symbolize the richness of the Canadian landscape - and the traditional trade of aboriginal peoples. By the nineteenth century, the fur trade in Canada had become an extensive economic enterprise, contributing to the formation and development of Canada as a nation and, according to Harold Innis, a key component in the foundation of Canadian economics. ${ }^{75}$ The fur trade began with beaver fur and expanded to meet the demands for beaver felt hats, which during

\footnotetext{
${ }^{72}$ C. Vodden and L.A. Frieday, "Geological Survey Of Canada," in The Canadian Encyclopedia. Historica Canada,1985. Article published February 8, 2006.

${ }^{73}$ Ibid.

74 Ibid.

75 Harold Adams Innis, The Fur Trade in Canada: An Introduction to Canadian Economic History (Toronto: University of Toronto Press, 1970).
} 
the seventeenth to nineteenth centuries were extremely fashionable in Europe. ${ }^{76}$ The fur trade not only contributed to settlement and exploration of the Canadian territory by waterways and the establishment of trade routes, but also ascertained the strong economic relationship between European settlers and the aboriginal peoples of Canada. Another component to successful nation building, according to settler colonial ideology (influenced heavily by British culture), is a manliness achieved by conquering nature and territory. A strong nation needed strong and virile men.

Daniel Coleman traces the history of Canadian "whiteness" and Britain's influence on settler colonialism and Canadian nation-building via an analysis of literature by looking at key masculine figures within late nineteenth and early twentieth century Canadian literature. In his analysis of the "muscular Christian" (in nineteenth century terms, "Christian manliness"), which reflected a specific set of social values and the male body, Coleman investigates the correlation between this image and how it would have applied to nation building in Canada. Coleman notes that the muscular Christian discourse was essentially ideal for Canadian imperialists who used this image "to support their campaign for sea-to-sea dominion." ${ }^{, 77}$ Most importantly, however, Coleman looks at the writing of Charles Kingsley and the influence he had on British manhood. Kingsley promoted the idea of reinvigorating British manhood by channeling an inherent, primal vigor, otherwise stifled by Victorian society. ${ }^{78}$ According to Kingsley's philosophy, a man could reconnect with this primal vigor by testing his vitality in the colonies, "where competition with indigenous people whose energies were not yet constrained by modern civilization called upon new levels of energy and discipline." ${ }^{, 79}$ Coleman connects Kingsley’s philosophy to the foundation of the Woodcraft Indians and the Boy Scouts, also influenced by the "muscular

\footnotetext{
${ }^{76}$ W.J. Eccles and John E. Foster, "Fur Trade," in The Canadian Encyclopedia. Historica Canada, 1985. Article published July 24, 2013.

${ }^{77}$ Daniel Coleman, White Civility: The Literary Project of English Canada (Toronto: University of Toronto Press Incorporated, 2006), 137.

${ }^{78}$ Ibid., 136.

${ }^{79}$ Ibid., 137.
} 
Christian" image. One could go as far as to say that the "muscular Christian" image that Coleman refers to and that Kingsley associated with a return to primal vitality, can be identified in the portraits of men dressed in Indian costume in the Notman studio, acting out tropes of Indianness, where notions of masculinity, conquering the wilderness, national strength and identity, and "white civility" converge in front of the portrait lens and manifest themselves in a photograph.

Against this context, the visual trope of lacrosse can be seen to connect Coleman's concept of "white civility" with Indian appropriation. In figure 36 (dated 1865), William George Beers stands against the "winter set" commonly used by the Notman studio wearing the same costume as Henry G. Vennor, only without the septum ring. Beers was a successful dentist, a recognized scholar who contributed to many journals in his field. ${ }^{80}$ He was also a successful sportsman, who advocated for sports in Canada and contributed articles to many magazines and periodicals on sports and Canadian life. ${ }^{81}$ Most importantly, however, was his association with the game of lacrosse. Beers began playing lacrosse at a very young age and studied games between the First Nations of Akwesasne and Kahnawake, both Mohawk communities. ${ }^{82}$ Although a variety of ball games involving the use of either one or two sticks with enclosed pockets were common among Native cultures, lacrosse was a modern version of a ball game that was played within the Iroquois Confederacy. Invented by the Mohawk, lacrosse was originally called tewaarathon. ${ }^{83}$ In 1860 , Beers published a small set of guidelines that outlined basic rules and regulations, believing that the sport, in order to be "accessible to whites," would need to be refined and standardized into a sport for gentlemen. ${ }^{84}$ Beers went on to found the National Lacrosse Association in Kingston, Ontario, in 1867 and shortly afterward published a book titled

\footnotetext{
${ }^{80}$ Thomas J. West, “BEERS, WILLIAM GEORGE," in Dictionary of Canadian Biography, Vol. 12 (University of Toronto/Université Laval, 2003), accessed July 9, 2015, http://www.biographi.ca/en/bio/beers_william_george_12E.html.

${ }^{81}$ Ibid.

${ }^{82}$ Ibid.

${ }^{83}$ Donald M. Fisher, Lacrosse: A History of the Game (Baltimore: Johns Hopkins University Press, 2002), 10 .

${ }^{84}$ West, "BEERS, WILLIAM GEORGE."
} 
Lacrosse: The National Game of Canada. ${ }^{85}$ A regular client of the Notman studio, Beers hired Notman to take a series of portraits of both indigenous and Anglo teams in order to promote the sport, coinciding with the publication of his book; these team photographs can also be found in the collection at the McCord Museum. ${ }^{86}$ Although Beers studied the game of lacrosse by watching First Nations players, he did not agree with how they played, making the distinction that "Indians played Lacrosse by instinct" and would never be as good as the white players who approached the game scientifically. ${ }^{87}$ Beers viewed the native game as being primitive, echoing the prevalent attitude that because the native way of life was savage and uncivilized, it needed refinement, as is clear in this statement by Beers on the modern version of the game:

The present game, improved and reduced to rule by whites, employs the greatest combination of physical and mental activity white man can sustain in recreation and is as much superior to the original as civilization is to barbarism. ${ }^{88}$

Donald M. Fisher in his book Lacrosse: A History of the Game explains what he calls the AngloCanadian appropriation of the Mohawk sport, in terms of three historical developments that took place in Canada during the mid-nineteenth century: "the marginalization of the Iroquois Confederacy, the formation of Victorian sporting culture and the birth of Canadian Nationalism." ${ }^{89}$ Interestingly, William George Beers was also a fierce nationalist, who toured Canada and America, speaking publicly on Canadian life, promoting both sports and patriotism. ${ }^{90}$ Fisher makes a key point in addressing the relationship between the formation of Canadian identity, the game of lacrosse and attitudes at the time towards aboriginal peoples:

The birth of modern lacrosse reflected the construction of a transcontinental Canadian national identity rooted in imperialistic Anglo-Canadian attitudes toward the New World environment and its native inhabitants. Essentially, virile Canadian national manhood could be made possible through the modernization of the white conception of the "noble savage."

\footnotetext{
${ }^{85}$ Ibid.

${ }^{86}$ Parsons, William Notman: Life \& Work, 19.

${ }^{87}$ West, "BEERS, WILLIAM GEORGE."

${ }^{88}$ Ibid.

${ }^{89}$ Fisher, Lacrosse: A History of the Game, 10.

${ }^{90}$ West, "BEERS, WILLIAM GEORGE."
} 
The attitude Fisher mentions and Beers exemplifies is echoed in the portrait of Beers dressed up in Native costume in the Notman studio. Beers appropriated Canadian aboriginal culture by wearing it as a costume, just as he contributed to the appropriation and "civilization" of the original Mohawk sport. Consequently, the connection between the subject and the game of lacrosse is significant, because it symbolizes the settler colonial appropriation of indigenous cultures, which is then visually represented in the portrait of Beers in Native costume.

The relationship between masculinity and conquering sport — and the wilderness - is thus evident when looking at Notman's portraits of men dressed in Native costumes. There is a common thread of masculinity that the portraits evoke, a manliness bolstered by wearing and acting out tropes of Indianness.

This chapter has shown, through a consideration of visual tropes of indigeneity, how the Notman studio portrayed — and bolstered — an image of ideal masculinity through the emulation of strong Indian types. Whereas the Notman studio seems, primarily, to have examples of settler colonial men playing Indian, photographs from the AMC collection feature a different group engaged in this practice, children. In the next chapter, I consider the significance of the analogy that they establish between, on the one hand, the discourse of childhood and, on the other hand, the image of the Indian. 


\section{Chapter 2: Children Playing Indian in the AMC Toronto Collection}

The Archive of Modern Conflict provides a wide array of examples of people playing Indian in the collection. In so doing, the archive serves as a fascinating visual account of the numerous ways in which this cultural phenomenon occurred within both North America and Europe. However, after spending a lot of time looking at this grouping of photographs and objects, what struck me most were the photographs of children who naively participated in this form of costuming and play. Snapshots of children in Indian costumes can commonly be found in photography collections and older family albums; I too have snapshots of my father and his siblings playing Indian as children (fig. 37).

According to Philip Deloria, the connection between Indians and children has a long history: Indians have been equated with the natural, simple, naïve, free-spirited and preliterate state of children; Indians were seen by settler colonialists as childlike, savage and unrefined, an image that helped these settler colonialists to justify dominion and forced assimilation. ${ }^{91}$

Children, conversely, were seen as little savages in need of civilization and refinement. ${ }^{92}$ Concurrently, the Indian type that children are photographed emulating, as we will see in the following images, was the "good Indian," or "noble savage," to which Berkhofer refers; this Indian was friendly, strong and masculine, handsome and in good physical shape, brave and a good hunter, while also kind-hearted, who lived a simple and wholesome life that was in tune with nature. It was this Indian type that could serve as a positive role model for children.

The significance of the practice of playing Indian as a child is two-fold. First, as Daniel Francis suggests, "many of the images we hold as adults are obtained in childhood and never abandoned: the Imaginary Indian is very much an Indian of Childhood." ${ }^{93}$ The stereotypical image of the Indian, which, as discussed in the first chapter, was influenced heavily by the Plains

${ }^{91}$ Deloria, Playing Indian, 106.

${ }^{92}$ Ibid., 54-55.

${ }^{93}$ Francis, The Imaginary Indian, 157. 
style of dress, is thus ingrained into children's impressionable minds from a very early age. This image is maintained through influences such as literature, images, film, education and summer camps, to which children were exposed; the majority of these coming from a "White"

perspective. ${ }^{94}$ More importantly, Francis points out that although not all of these images of the Indian were negative, children were not really exposed to authentic Native cultures or the realities they faced, namely, the fact that by the early twentieth century, Natives were displaced, living on reserves and marginalized. ${ }^{95}$ These constructed images that children re-enacted during play represented, in many ways, the prejudices of the dominant settler colonial culture.

Equally important to note is that the image of the Indian portrayed by children was one of the past, which no longer fit into modern society; this nostalgic representation transplanted the traditional and, in most cases Plains Indian, into an unlikely and modern context, as seen in the Notman studio portraits. The traditional way of life of Native peoples during the height of colonialism in the nineteenth century was, by that time period, drastically altered. Decades of conquest, displacement, and, eventually, forced assimilation led to a period when Native peoples were no longer seen as being able to fit into the European-based model of industrialization and modernization. Instead, Native peoples were seen by settler colonials as fundamentally, antimodern. If Native peoples were to continue to exist in settler colonial society and culture, they would need to assimilate, in many cases adopt Christian religion and give up their cultural ceremonies, dances, sustainable approach to hunting and gathering, and participate in economic trade and agriculture. While the aforementioned is a long and complex history, the most relevant part of this history, is that by the time the medium of photography was invented and refined, the traditional, pre-contact Indian and the Indian way of life revered and emulated by children, did not exist in modern society.

\footnotetext{
${ }^{94}$ Ibid., 58.

${ }^{95}$ Ibid., 158.
} 
As Philip Deloria and subsequent theorists suggest, playing Indian was also an extension of the anti-modern movement, a reaction against urbanization and the stresses associated with modern society, and a desire to return to more primitive ways of life and be in tune with nature, by way of a primitive construction of the Indian "Other." Moreover, the act of playing Indian as an anti-modern behavior was encouraged by Indian programming at children's summer camps, as discussed by Sharon Wall in her article on playing Indian at Ontario Summer Camps, so that children were encouraged to socialize, learn and develop a sense of community by emulating traditional and anti-modern aspects of aboriginal culture. This approach used by camps was really what Wall refers to as a "racialized expression of $20^{\text {th }}$ century anti-modernism" that imposed an adult view, stemming from settler colonial attitudes, onto children. ${ }^{96}$ Daniel Francis, drawing from Deloria's theory, suggests that children loved to play Indian, as the Indian represented many things that attracted children: they were removed from the conventions of modern society, seen as wild and free-spirited, living in nature among the animals and in a world devoid of rules and restrictions (fig. 38). ${ }^{97}$

American psychologist G. Stanley Hall adds that playing Indian develops masculinity and strength of character, setting in motion a transition from savagery to civilization. ${ }^{98}$ Hall believed that, in order to grow up and face the challenges of modernity, children would need to become civilized by first being allowed to evolve through various stages of primitive and savage behavior, which he equated with the behavior and traditional way of life of Native peoples.

Deloria notes the influence of Hall's theory on Ernest Thompson Seton's work, which promoted the idea of going back to a more primitive way of life, rooted in nature, where the Indian served as a positive role model for young North American boys in their transition into manhood and members of modern society. ${ }^{99}$ Seton was a naturalist, lecturer, prolific author and

\footnotetext{
${ }_{96}^{6}$ Wall, "Totem Poles, Teepees, and Token Traditions: playing Indian at Ontario Summer Camps," 2.

${ }^{97}$ Francis, The Imaginary Indian, 157.

${ }_{99}^{98}$ Deloria, Playing Indian, 107.

${ }^{99}$ Ibid.
} 
illustrator of plants and animals. More importantly, he founded the League of Woodcraft Indians in the early twentieth century, an outdoor youth group for boys and one of the antecedents to the Boy Scouts of America, for which Seton became the first "Chief Scout." An adaptation of this group for girls also existed, called the Camp Fire Girls. Scouting became popular within North America and Europe during the early twentieth century, Seton, among others, was credited with being one of the pioneers of the scouting movement. Unlike most of his colleagues, Seton admired the aboriginal culture and way of life, believing it to be superior, a perspective that eventually cost him his popularity and role within the Boy Scouts of America. ${ }^{100}$ Seton's Indian, however, was also a fantasy of a pre-contact Indian, untainted by white settler colonialists and like the many traditions, rituals and cultural customs Seton appropriated, was borrowed from various Native cultures. According to Seton, this manliness and strength that male Native North Americans embodied was perceived as an ideal role model for young boys. Summer camps for boys drew on the perceived masculinity and ferocity of this Indian image; boys were encouraged to model this image by engaging in "savage" practices such as scalping and participating in games of settlers and Indians. ${ }^{101}$ The boys were encouraged to be warriors or hunters, whereas girls were encouraged to indulge in Indian arts and crafts and followed programming that was deemed more feminine. ${ }^{102}$

Drawing from these scholarly insights, which situate playing Indian within the antimodern movement, this chapter examines how the representation of children engaged in this practice of playing Indian expresses a nostalgic rejection of civilization at the same time that it marks a symbolic first step toward civilization. It is through playing Indian (a practice of appropriation that is distinct from being Indian) that the white child is able to advance to a civilized state.

\footnotetext{
100 Francis, The Imaginary Indian, 163.

${ }^{101}$ Wall, "Totem Poles, Teepees, and Token Traditions: playing Indian at Ontario Summer Camps," 6.

102 Ibid., 6.
} 
Figure 39 is a stereocard, one of four, of a young boy dressed in a generic looking Indian costume, kneeling and aiming a bow and arrow. Its inscription reads: "Tis a boys delight to play Indian.” The photograph was taken in a natural looking setting, meant to signify "wilderness." In figure 40, the second stereocard, we see the same boy, but in a different pose. These photographs, which were likely staged and taken by the boy's family, were evidently well thought-out, given the different poses and the fact that they are in stereocard format, intended to be viewed as a series. Interestingly, however, are the two very masculine characters this boy has been photographed playing, as seen again in figure 41 , the third stereocard of the same boy playing a cowboy, with the addition of a hat and sitting on a toy horse, where the inscription reads: "A Juvenile Cowboy.” Most significantly, as these photographs illustrate, children could play hunters, warriors and heroic cowboys. In so doing, they evoke a sense of bravery and strength, and for young boys specifically, masculinity. The "wilderness" setting in these stereocard photographs serves to enhance the representation of the two opposing figures, the Indian and the cowboy and their parallel conquest of nature. This idea of emulating a very masculine Indian image is easily identified again in figure 42 , which is a cabinet card studio portrait of a young boy majestically posed, kneeling and holding a rifle, and again in figure 43, a snapshot photograph of another young boy posed as a warrior with a bow and arrow, also armed with a tomahawk and shield that has a Plains chief's head painted on it.

In the game of cowboys and Indians children could play both the "good" and "bad" Indian, just as they could play both the "outlaw" and the "heroic" cowboy. ${ }^{103}$ Unlike the "good" Indian mentioned earlier, promoted by Seton as a positive role model for children, the "bad" Indian was also a popular choice for children to play, as it was this Indian that would then be defeated and killed by the heroic cowboy. The game of cowboys and Indians became popular

\footnotetext{
${ }^{103}$ Ann McGrath, "Playing Colonial: Cowgirls, Cowboys, and Indians in Australia and North America," Journal of Colonialism and Colonial History 2, no. 1 (2001): 3, accessed August 18th, 2015, https://muse.jhu.edu/.
} 
beginning in the late nineteenth century and remained so up until about the $1970 \mathrm{~s} .{ }^{104}$ The game was a cultural phenomenon originating from the United States based on the romanticized history of the conquest of the American West, but as Ann McGrath points out, was also widespread in Europe and countries like Australia in the form of "squatters and Aborigines," where the aboriginal peoples of Australia suffered the same settler colonial experience as Native North Americans. In her journal article "Playing Colonial: Cowgirls, Cowboys, and Indians in Australia and North America," McGrath argues that the game of cowboys and Indians was "a cultural pairing of empires of the imagination where history became performance and where global "modern" identity was installed, historicized, and contested by both children and adults." 105 More importantly, however, McGrath points out that this seemingly innocent children's game is implicit in a far more serious goal of teaching gender and race identity to children within the greater context of nation building and that the game itself created "allegorical maps of settler land relations that children carried into adulthood." ${ }^{106}$ As a final point, McGrath also refers to Rayna Green's work and her article “The Tribe Called Wannabee: Playing Indian in America and Europe, "where Green argues that Baden Powell, another prominent founder of the scouting movement and highly influential throughout the British Empire, was partially responsible for diluting the settler colonial experience into the children's game of "cowboys and Indians."107

The use of the generic Plains Indian costume becomes quite evident again when looking at these photographs as a group in figure 44 - all the costumes look strikingly similar. So what actually evokes Indianness in these portraits is a costume that includes fringe, a feathered headdress and some sort of "Indian" weaponry, such as a bow and arrow, shield, tomahawk and gun. Looking closely at the setting in figure 45 , also included in the above grouping, the sand and long grass seem more appropriate for the Plains-inspired Indian costume that he wears, in contrast

\footnotetext{
${ }^{104}$ Ibid., 1.

${ }^{105}$ Ibid., 2.

${ }^{106}$ Ibid., 12.

${ }^{107}$ Ibid., 13.
} 
to the setting of the studio portrait of the young boy with the gun. In a sense these photographs of children playing Indian visually represent an attempt to enhance Indianness through a connection to nature, by placing the Indian in a setting signifying wilderness, but in other cases, the Indian is again displaced in the setting of the photography studio, or the industrial environment.

As Wall mentions about the Indian programming at summer camps, girls were meant to embody a more feminine Indian image. In contrast, the girl in figure 46 is, in this studio portrait, quite elegantly posed with her tomahawk, sitting on an ornate tapestry. These gender specific forms of Indianness were repeated in the photography studio, where boys and men were brave chiefs, warriors, or hunters, and girls and women seemed to follow a more romanticized "Pocahontas" model. According to Rayna Green in her article "The Pocahontas Perplex: The Image of Indian Women in American Culture," the very gender stereotyped and romanticized Pocahontas representation of Native women should be understood as a painful metaphor for the "Indian-White" experience. Both the images of "Pocahontas" and the "Squaw" have contributed to the negative and degrading experience that Native women have faced within the confines of patriarchal colonialism. ${ }^{108}$ According to Green, both Native women and men have been defined by their relationships with white men, but Native women have been laden by the very narrow definition that has stemmed from the national mythos of the Pocahontas story. ${ }^{109}$ Bonita Lawrence talks about a gendered notion of Indianness within Canada stemming from Canadian regulation of Native identity within the Indian Act, which promoted gender domination and thus placed Native women in an inferior position to men. ${ }^{110}$ These gendered forms of Indianness, which Wall also refers to in relationship to camp activities for boys and girls, were more in line with settler colonial ideology and supported Western notions of gender roles. Ironically, the

\footnotetext{
108 Rayna Green, “The Pocahontas Perplex: The Image of Indian Women in American Culture,” The Massachusetts Review 16, no. 4 (Autumn 1975): 698-714, accessed September 3, 2015 , http://www.jstor.org/stable/25088595.

109 Ibid., 17.

110 Bonita Lawrence,. "Gender, Race, and the Regulation of Native Identity in Canada and the United States: An Overview," Hypatia 18, no. 2 (Spring, 2003): 3-31, accessed August 18, 2015, http://www.jstor.org/stable/3811009. pg. 7.
} 
Plains Indian cultures, which both children and adults seem to be emulating while costumed and playing Indian, actually, for the most part, believed in an egalitarian society where a complementary role existed between men and women and one role was not more important than the other. ${ }^{111}$ These egalitarian societal structures are referred to as "Sacred Kinship Traditions," destroyed by the gendered process of settler colonialism. ${ }^{112}$ The female image of the Indian has thus been shaped by masculine settler colonial ideology, as Jaimes Guerrero points out, “what sexist Western Europeans mistook as the subjugation of Native men to their women was actually the gender role dynamics of an egalitarian society that valued both men and women.",113

Figure 47 is a studio portrait taken in Colorado, in 1909, and is a prime example of these gender roles, clearly personifying all of the tropes of Indianness. The three youth are carefully posed on rocks among "grass," set against a backdrop of "wilderness." In this situation, the outdoors is brought indoors, as was the case in the Notman studio sets, where an elaborate "nature" set is used to, once again, enhance the feeling of Indianness. The young man is dressed as a Plains chief, although in reality he is too young to be a chief and to wear such a headdress. He is also in a dominant stance, as he is positioned above the two young women; the young woman on the viewer's right is in character, more so than the others. The fact that she bends forward, almost cowering with her palm open facing forward, another common trope, suggests that she is in a submissive position, not only to the male subject in the photograph, but also to the viewer. This is somewhat ironic, as Native peoples photographed during this time period were often in a submissive position vis-á-vis the photographer, but in this case, it is the white girl

\footnotetext{
111 James Guerrero, "Patriarchal Colonialism" and Indigenism: Implications for Native Feminist Spirituality and Native Womanism," Hypatia 18, no. 2 (Spring, 2003): 58-69, accessed August 18, 2015, http://www.jstor.org/stable/3811011.pg. 8-9.

${ }^{112}$ Ibid., 11.

${ }^{113}$ Ibid.
} 
unknowingly acting out a very real situation faced by Native peoples, while being photographed by practitioners of the dominant culture. ${ }^{114}$

In figure 48, eight children are portrayed playing Indian. The girls are wearing fringed dresses, headbands with feathers and fake braided hair, while the boy in the front is posed with a bow and arrow and wearing what is meant to mimic a breechclout. Three boys are pretending to play what look like hand drums with "skins" they made themselves and some also have their faces painted. One of the girls carries a toy baby in an imitation cradleboard. The photograph was definitely staged by the person taking it and includes an element of performance as well. The careful staging, poses, and pieced together, self-made costumes exemplify many of the tropes discussed earlier. The verso indicates this photograph belongs to the record photography collection of the University of Waterloo and was likely taken in that area. It is obvious that the children are within a suburban, or urban setting, with planted trees and buildings in the background that appear industrial. The contrast between the children in what are meant to be traditional Plains Native costumes set against a modern landscape reinforces, again, the notion of displacement, so that this image of the Indian appears incongruous next to the figures of modern society.

\footnotetext{
114 Native peoples did not necessarily visually appear submissive in the various ethnographic and documentary photographs made of them during the nineteenth and early twentieth centuries, however, the majority of these photographs were made by the dominant culture (white European, or North American photographers) and in most cases Native peoples did not really know what their images were being used for, which put them in a vulnerable position in relationship to the photographer. The "stoic" (although a stereotype) and often serious expression captured of Native peoples in these photographs did not only have to do with the slower exposure times, or limitations of camera technology, but moreover, the ambiguous position they were in while being photographed; uncertainty about why the image was being made and an uncertainty about the future of their peoples.
} 


\section{Conclusion}

In this thesis I have focused on material from two collections, the Notman Studio collection held at the McCord Museum and the Archive of Modern Conflict, in developing my argument, but as noted in the introduction, these images belong to a much larger framework of people "playing Indian," of which there are countless photographic examples. The examples found in these two collections consider two different contexts in which playing Indian occurred, one among white settler colonialists in Montreal society, and the other among children in a variety of settings both in and outside the studio.

I have looked at the cultural significance of the photographic representation of playing Indian, that is, the portrayal of a practice in which non-Native peoples dressed up in Native North American costume. I have also looked at the relationship that these photographs have to the greater context of people playing Indian, by drawing directly from literature and situating the photographs within critical scholarship on the subject of playing Indian and settler colonial attitudes towards Native North Americans during both the nineteenth and twentieth centuries. By examining the meanings of such visual tropes of Indianness, I have shown the extent to which photographs in both the Notman studio collection and the Archive of Modern Conflict collection of people playing Indian reinforce settler colonial ideology and how these photographs visually represent dominance and claim over indigenous culture, while at the same time illuminate the desire of white society to domesticate, and thereby symbolically modernize, so-called "savage" Indians.

The Indian dress that settler colonialists and their children put on in both the studio photographs of William Notman and Co. and those both in and outside the studio found in the AMC collection represent what Thomas King, in his book The Inconvenient Indian, refers to as "Dead Indians." According to King, "Dead Indians" are the only antiquity that North Americans - with their short history, in comparison to that of Europeans - can claim and that this version of the Indian, as Philip Deloria has also argued, provided settler colonialists with a 
connection to the territory and wilderness that they conquered and took from Native peoples. This process, in turn, strengthened national identity and helped symbolically establish a heritage to a land where settlers were essentially immigrants. King argues that this image of the Indian shaped by settler colonial ideology was and continues to be the image of the Indian that prevails to this day:

North America has had a long association with Natives People, but despite the history that the two groups have shared, North America no longer sees Indians. What it sees are war bonnets, beaded shirts, fringed deerskin dresses, loincloths, headbands, feathered lances, tomahawks, moccasins, face paint, and bone chokers. These bits of cultural debris - authentic and constructed - are what literary theorists like to call "signifiers." 115

As King points out, these signifiers of Indianness solidified an image of the Indian that came to represent what all Indians looked like to most non-Native peoples; this image was emulated in the practice of dressing up and playing Indian, as visually represented in the photographs in both the Notman Studio collection and the AMC collection. I have established that one of the overarching tropes of "Indianness" is the representation of Plains cultures within the costumes used for playing Indian and have traced the development of this Plains-inspired Indian image through scholarship. Revisiting the concept of two "Indian types"- the "good" Indian and the "bad" Indian - as identified by Berkhofer, it seems that most male subjects in the photographs I examined in both collections depict the "good" and, in other words, "noble savage." This "good" Indian was strong, honourable, a successful hunter and skilled outdoorsman, physically attractive, in good form and, most significantly, very masculine. In this manner, the photographs project a nostalgic fantasy rather than an accurate portrayal of Indians, both in Canada and the United States. In addition, both the Notman studio portraits of men dressed in Indian costume and the representations of children playing Indian in the AMC collection, masculinity was bolstered by acting out tropes of Indianness.

\footnotetext{
115 Thomas King, The Inconvenient Indian: A Curious Account of Native People in North America (Anchor Canada, 2013), 54.
} 
By identifying visual tropes of indigeneity I have considered how the Notman studio portrayed and reinforced an image of masculinity through the emulation of the aforementioned Indian type and how this relates to an overall discourse on masculinity and nation-building. I also examined how a claim to indigeneity is represented visually through Canadian signifiers by looking at studio sets and props and, additionally, through an analysis of the context and background of the subjects photographed in the studio.

Drawing again from existing scholarship, I have explored the relationship between children and the image of the Indian in the AMC collection. By situating the practice of playing Indian among children within the anti-modern movement, I have considered how these photographs project a nostalgic and pre-modern version of the Indian and how this Indian was also used to teach children how to lay claim to national identity.

The importance of researching and analyzing these images and attempting to understand their cultural significance is something that could and should be taken much further, as this form of cultural appropriation by way of acting out tropes of Indianness is, unfortunately, still manifesting itself visually within the medium of photography in 2015 , as seen in figure 50 and figure 51. Within the last few years, some attention has been paid to the inappropriate use of costume headdresses at music festivals and in the fashion industry. ${ }^{116}$ Attention has effectively been brought to these forms of cultural appropriation via the circulation of photographs, such as the examples seen in figure 50 and figure 51 . I believe there is potential for future research on this subject, as I have only discussed a selection of these images and many more exist in not only the

\footnotetext{
116 For news articles on this topic see: http:/www.ctvnews.ca/canada/canadian-music-festivals-ban-first-nations-headdress-over-culturalinsensitivity-1.2473299 http://www.theguardian.com/culture/2015/jul/17/osheaga-music-festival-headdress-cultural-appropriation http://www.thestar.com/entertainment/music/2015/07/14/osheaga-music-festival-bans-wearingheaddresses-as-fashion-accessories.html http://www.cbc.ca/news/canada/montreal/headdresses-banned-at-osheaga-music-festival-1.3150265 http://www.theguardian.com/fashion/2014/jul/30/why-the-fashion-headdress-must-be-stopped $\mathrm{http}$ ://indiancountrytodaymedianetwork.com/2014/06/04/oh-pharrell-part-native-american-heres-why-itdoesnt-matter-155149 http://www.cbc.ca/news/aboriginal/pharrell-williams-sorry-for-wearing-first-nation-headdress-1.2664513
} 
AMC collection that I did not address, but other collections as well, which serve as a visual account of the various contexts under which this form of colonial costuming existed and, unfortunately, continues to exist today. 

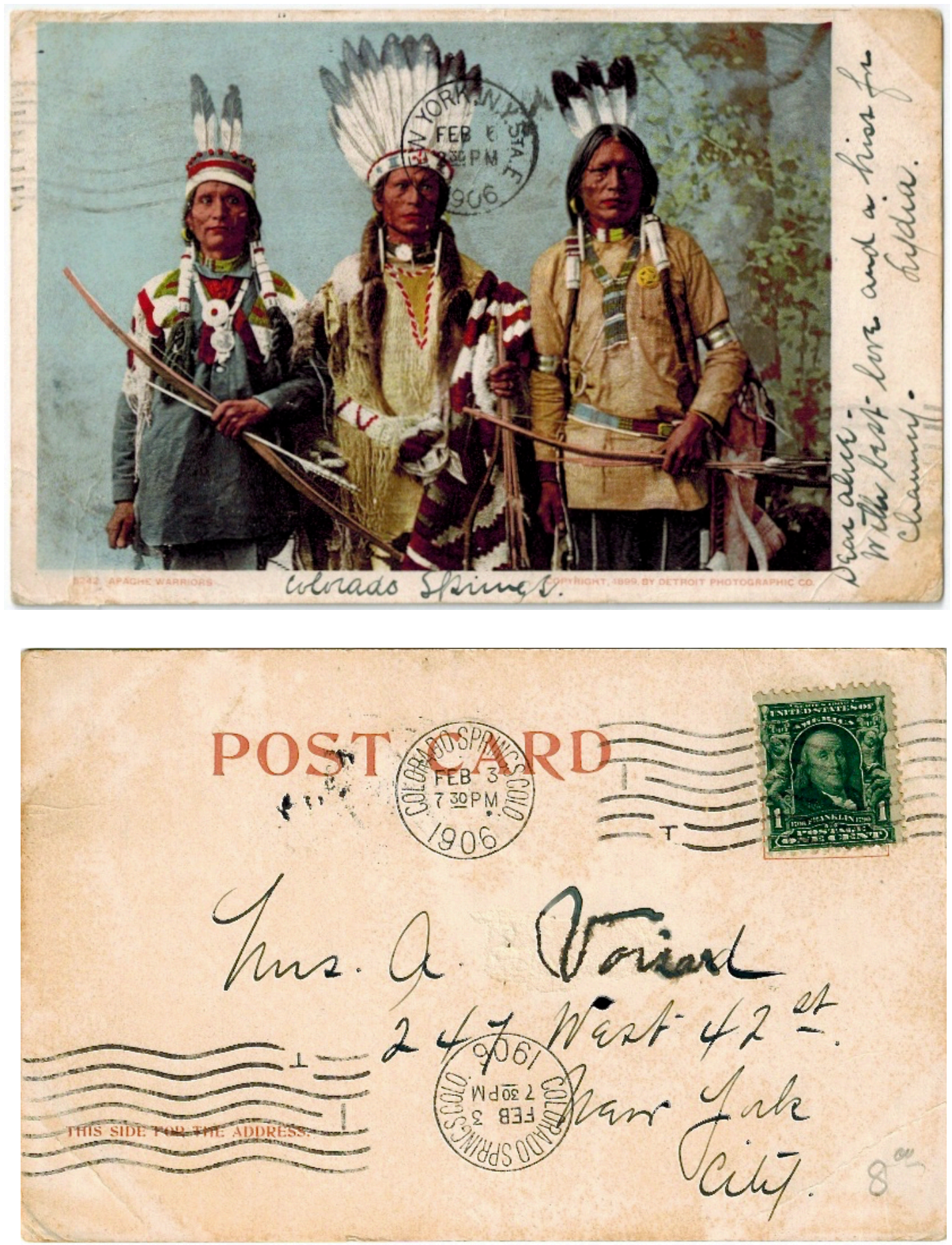

Figure 1. Colour postcard of three "Apache Warriors," 1899. Detroit Photographic Company. Personal Collection. 


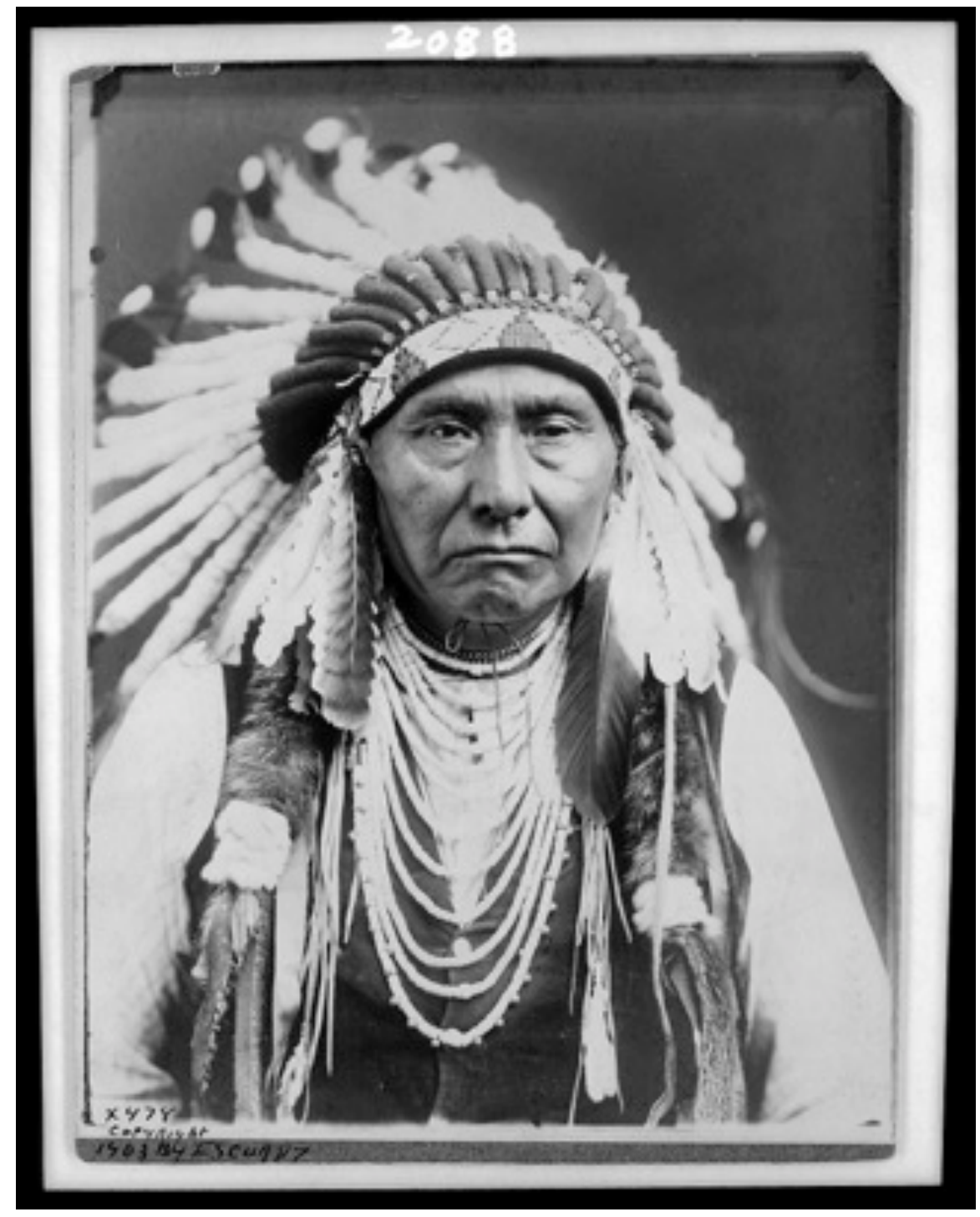

Figure 2. Chief Joseph-Nez Percé, ca.1903. Edward S. Curtis. Gelatin silver print. Library of Congress Prints and Photographic Division. 


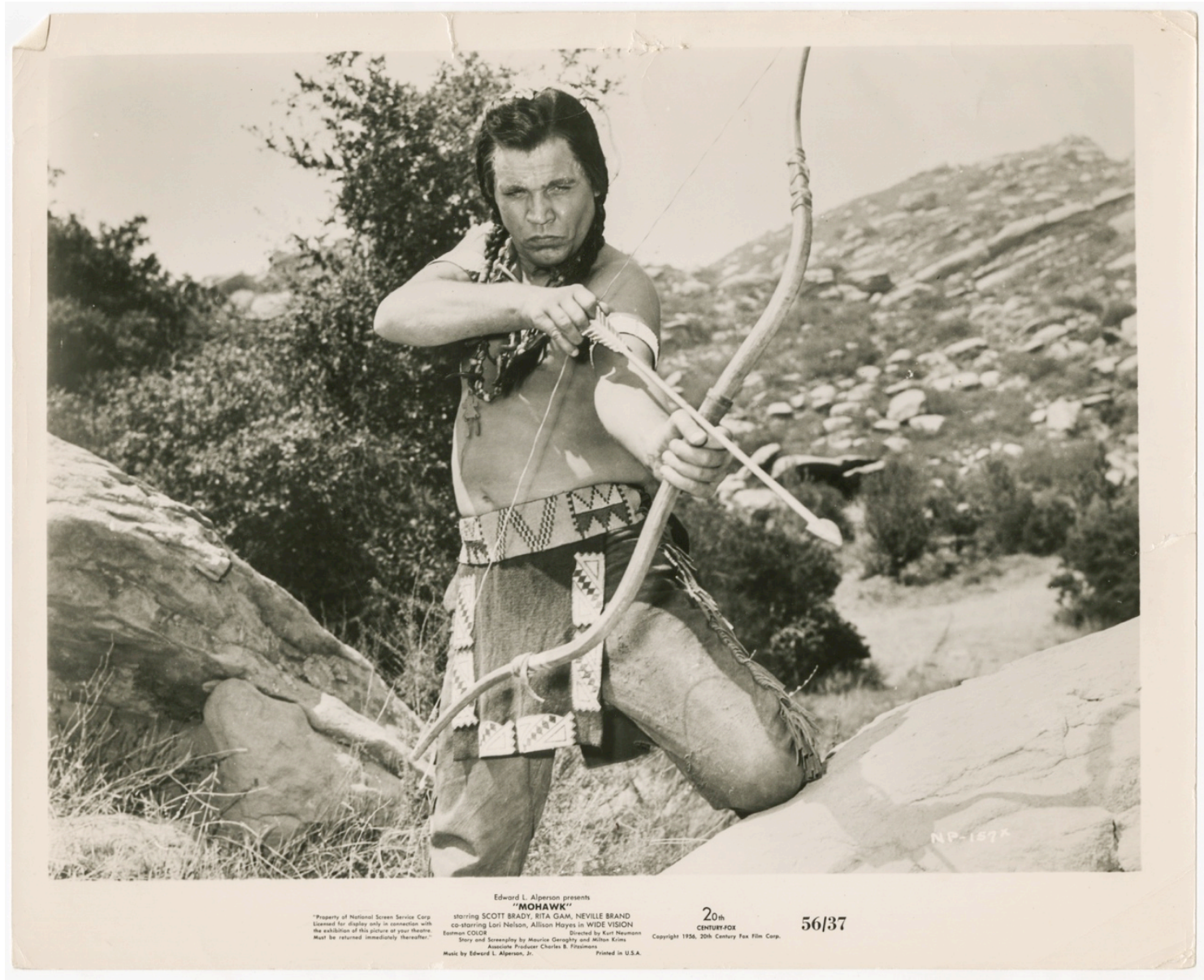

Figure 3. Promotional photograph for the film Mohawk, starring Scott Brady, 1956. $20^{\text {th }}$ Century Fox Film Corp. Gelatin silver print. First Nations Collection at the Archive of Modern Conflict Toronto. 


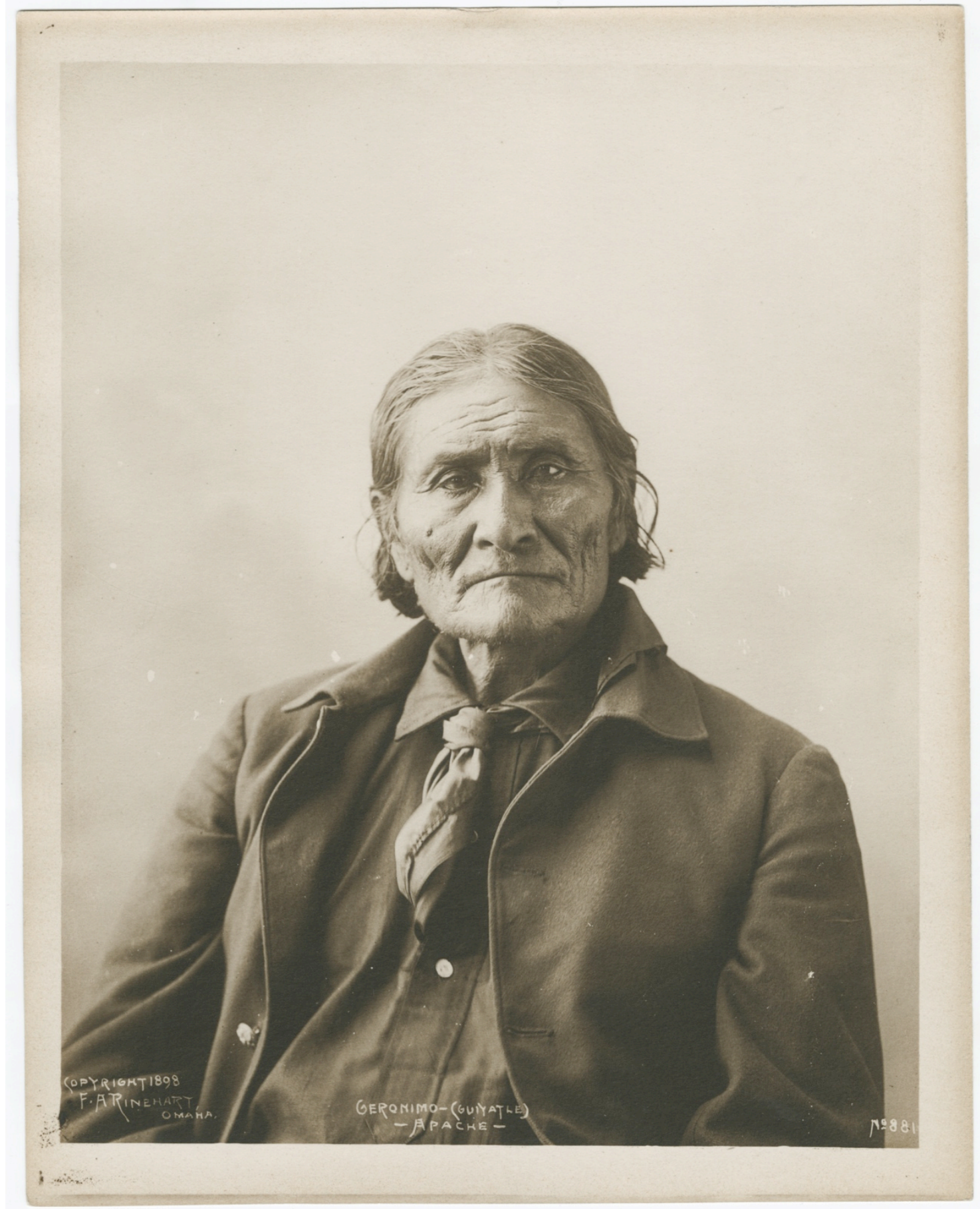

Figure 4. Geronimo (Guiyatle)-Apache, 1898. Frank A. Rinehart. Platinum print. First Nations Collection at the Archive of Modern Conflict Toronto. 


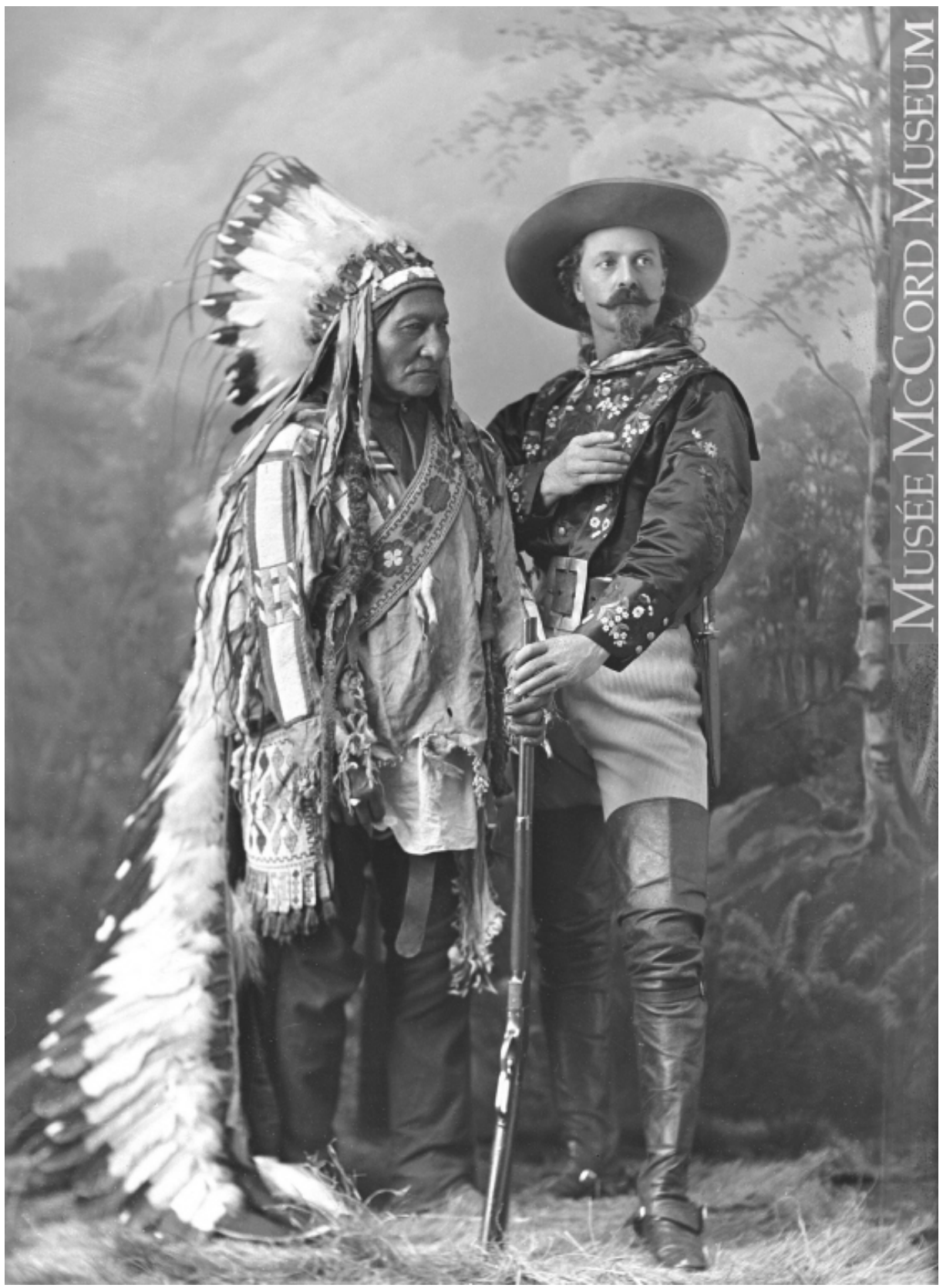

Figure 5. Sitting Bull and Buffalo Bill, Montreal, QC, 1885. William Notman \& Son. Dry gelatin silver glass plate negative. Notman Photographic Archives at the McCord Museum. 


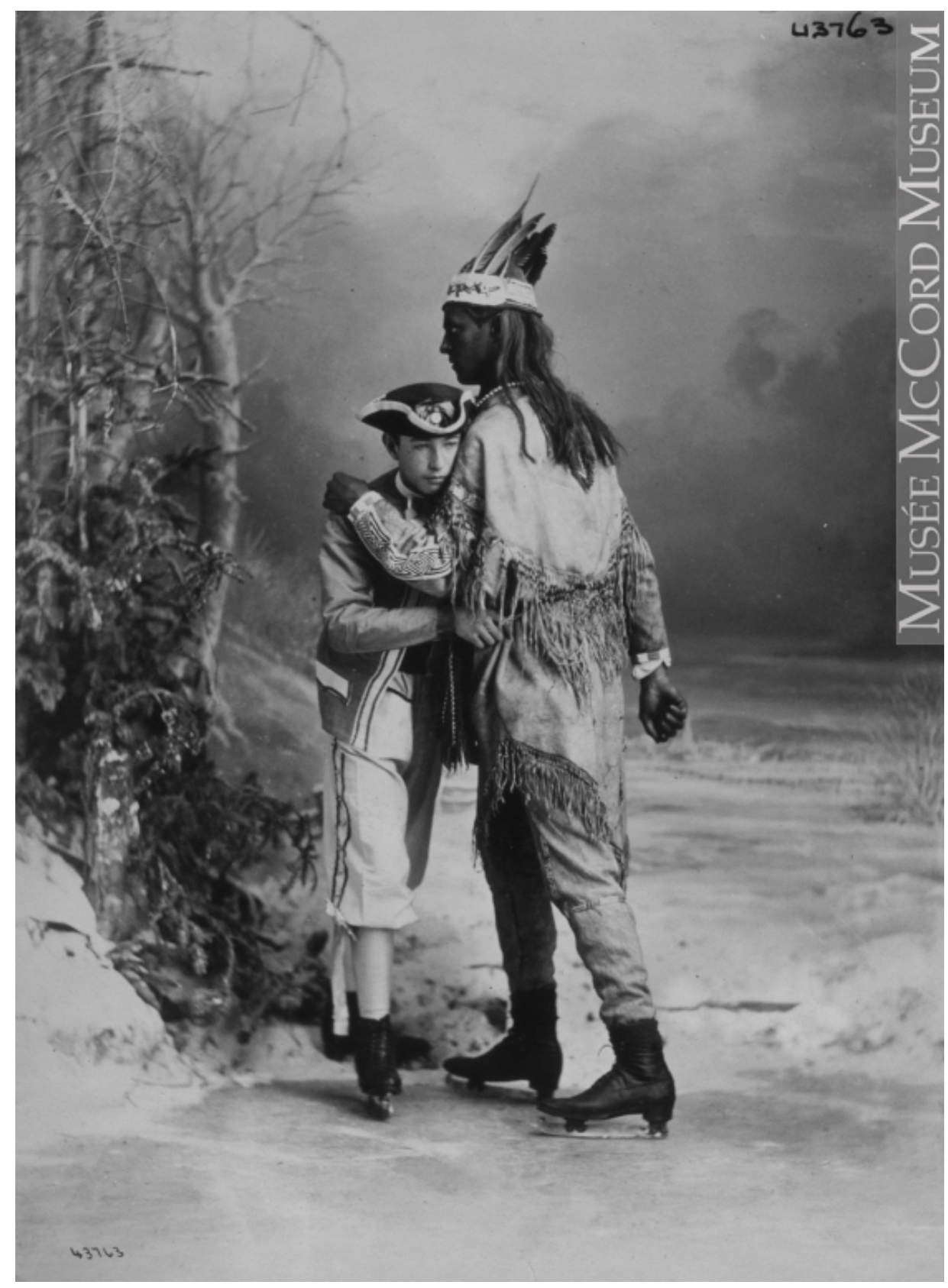

Figure 6. J. Whitney and H. Lyman, posed for a composite, Montreal, QC, 1870. William Notman \& Son. Dry gelatin silver glass plate negative. Notman Photographic Archives at the McCord Museum. 


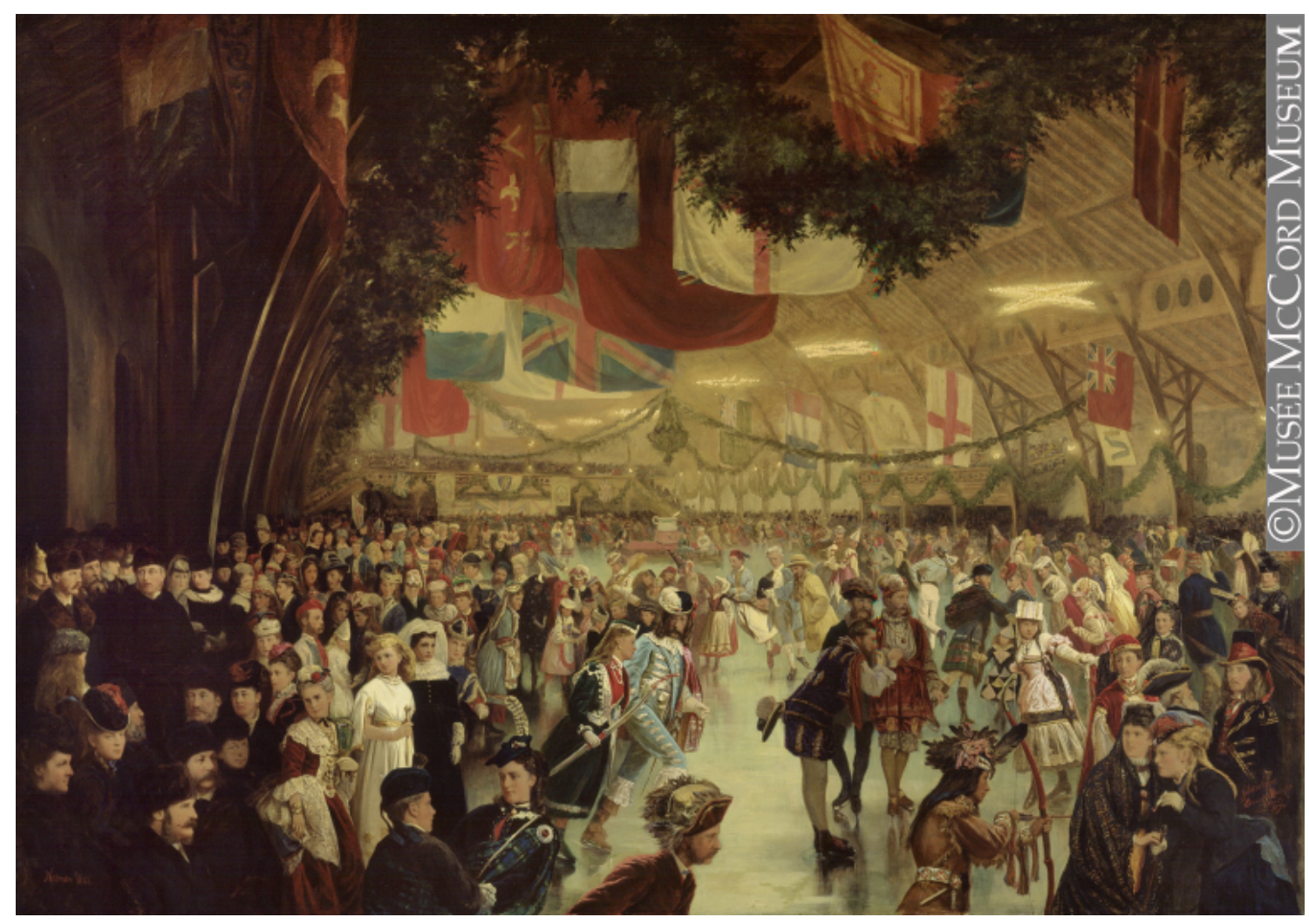

Figure 7. Skating Carnival, Victoria Rink, painted composite, Montreal, QC, 1870. William Notman \& Son. Oil painted albumen print on canvas. Notman Photographic Archives at the McCord Museum. 


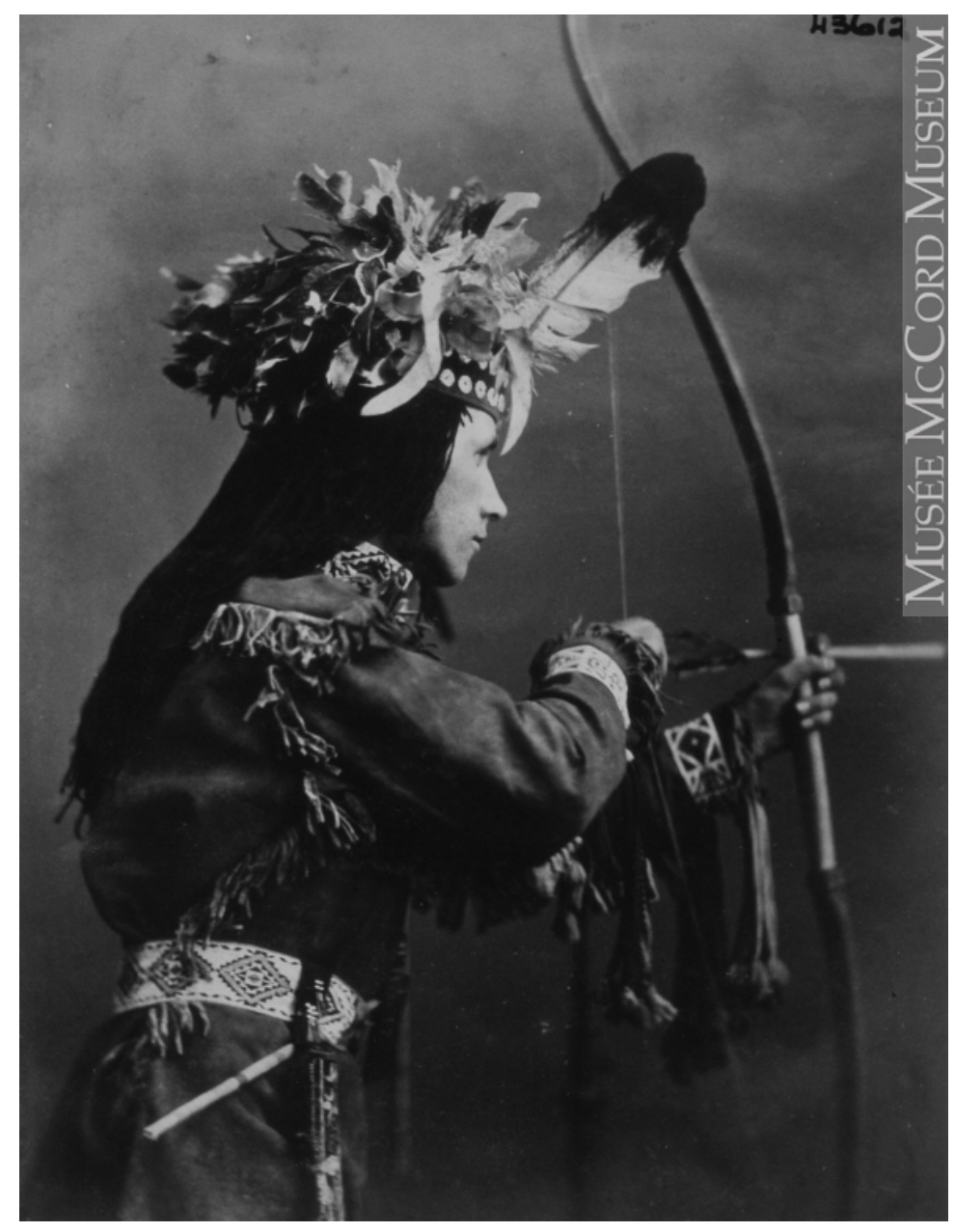

Figure 8. Mr. Reynolds as "Quewaygoosquequamteros," posed for composite, Montreal, QC, 1870. William Notman \& Son. Albumen print mounted on paper. Notman Photographic Archives at the McCord Museum.

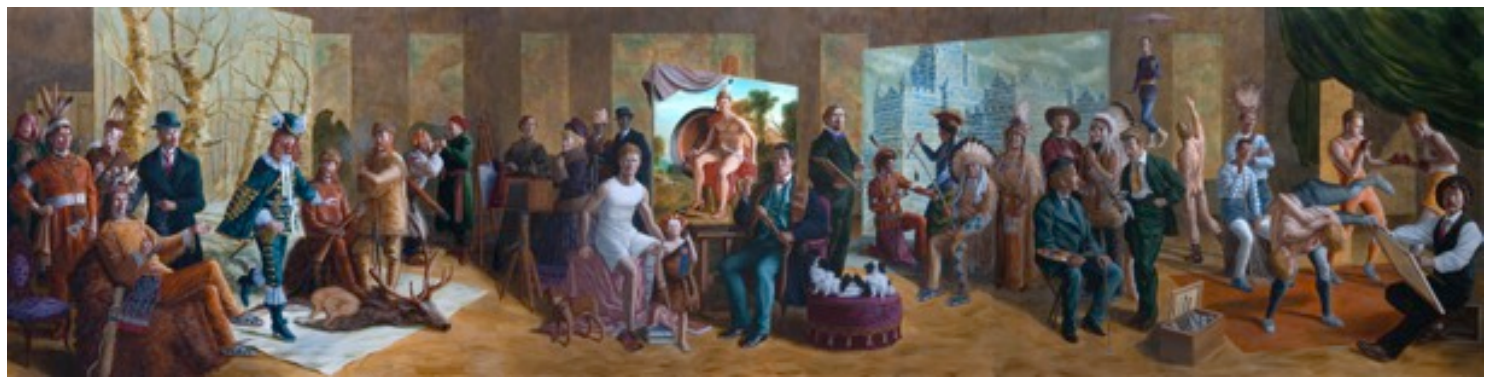

Figure 9. Welcome to the Studio: An Allegory for Artistic Reflection and Transformation, 2014. Kent Monkman. Acrylic on canvas. Courtesy of the McCord Museum. 


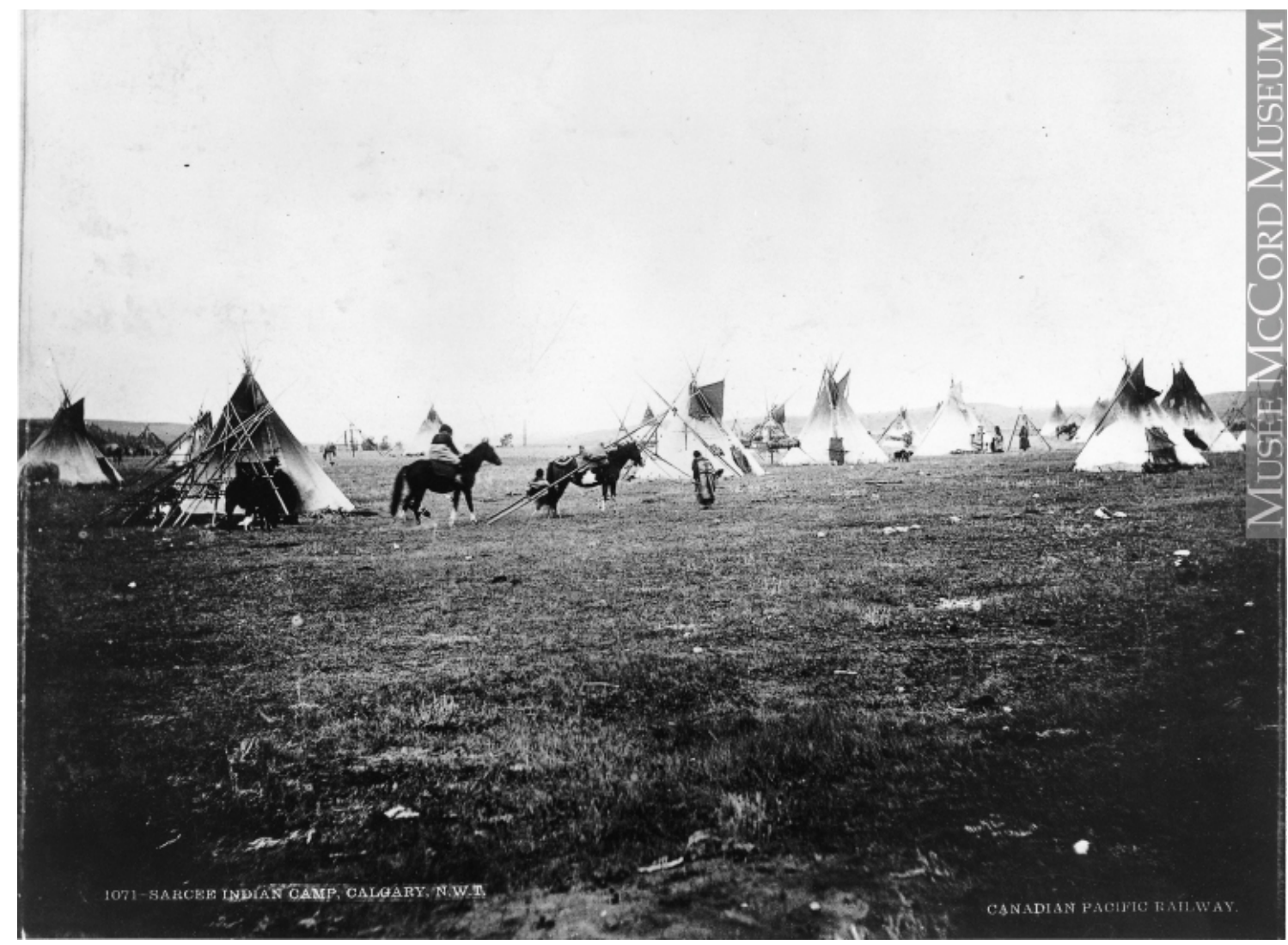

Figure 10. Sarcee Indian Camp, Calgary, N.W.T, for the Canadian Pacific Railway, 1892. William Notman \& Son. Gelatin silver print mounted on card. Notman Photographic Archives at the McCord Museum. 


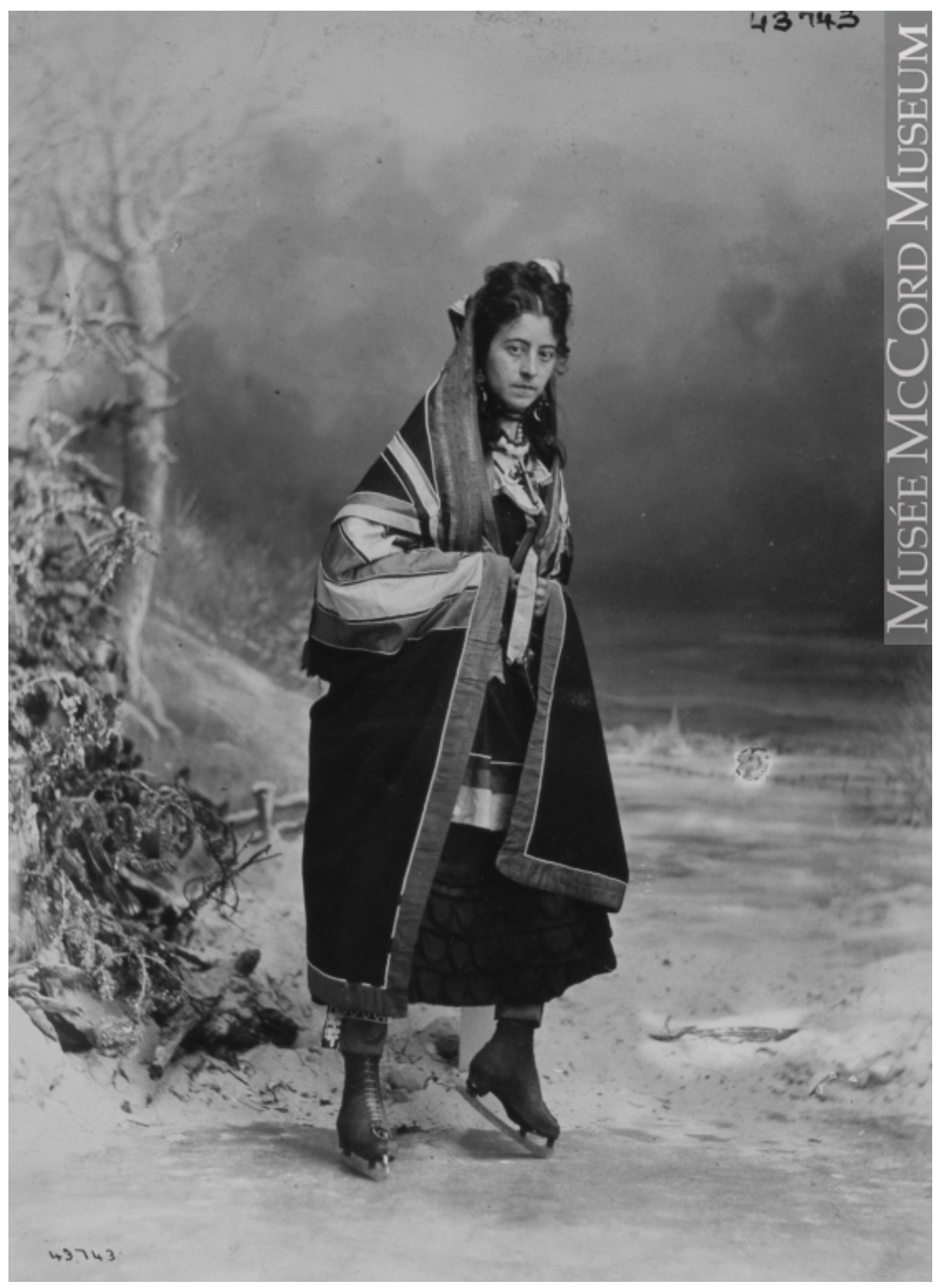

Figure 11. Miss Plimsoll as "Indian Woman," posed for a composite, Montreal, QC, 1870. William Notman. Albumen print mounted on paper. Notman Photographic Archives at the McCord Museum. 


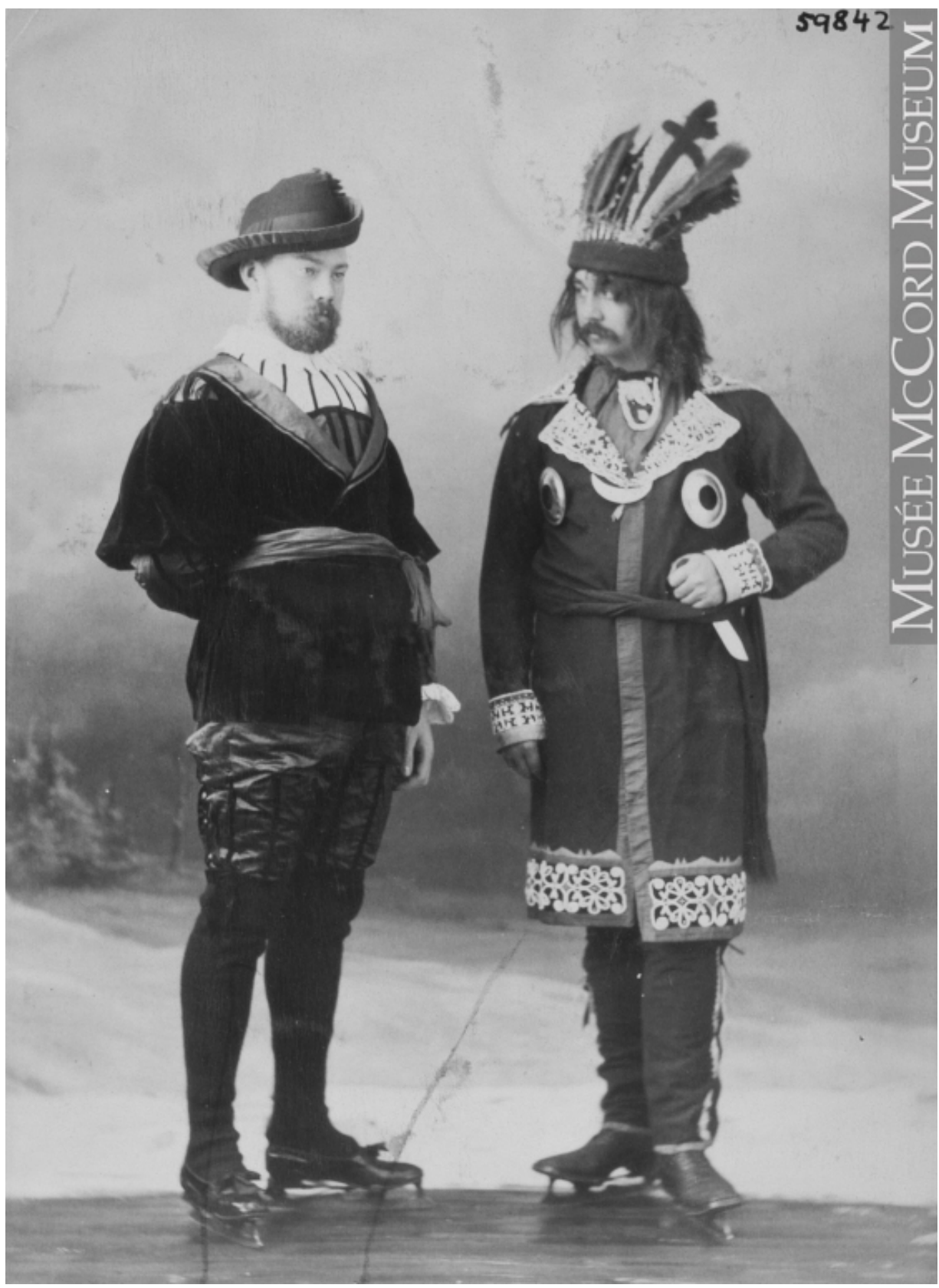

Figure 12. James Fletcher as "Che-oc-che-moo-che" or "White Maple Leaf, the Micmac" and friend, posed for a composite, Montreal, QC, 1881. Notman \& Sandham. Albumen print mounted on paper. Notman Photographic Archives at the McCord Museum. 


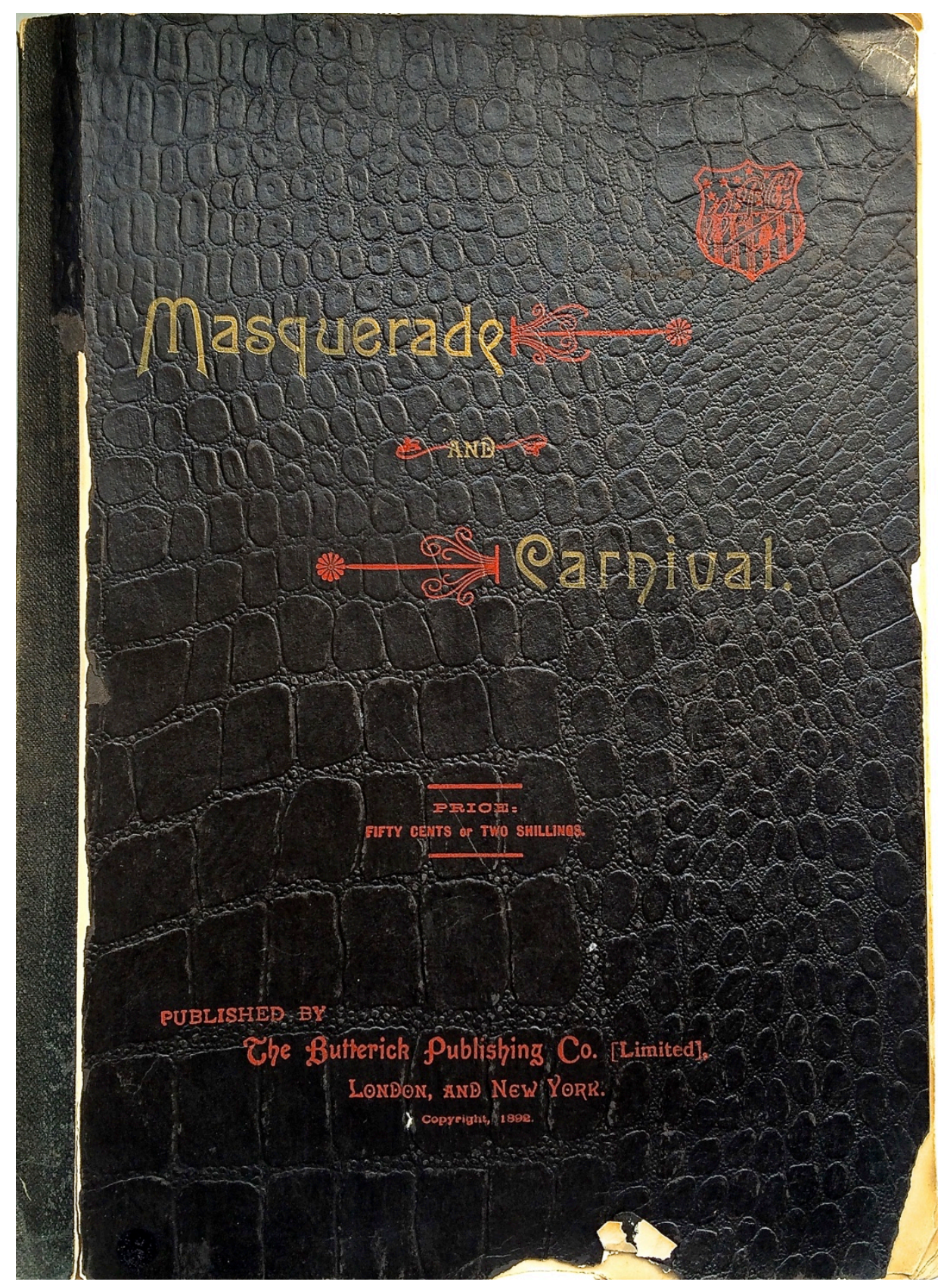

Figure 13. Cover of the book Masquerade and Carnival, 1892. The Butterick Publishing Company Limited. Courtesy of the McCord Museum. 
Figure No. 25.-Oriental Costume.-This silk is used for the sleeves and chemisette, and unique costume is exceedingly simple and may be also for the jacket and cap, while the wool is made at home. It is composed as follows: Shirt of used for the dress. A long, white gauze veil is white silk gathered about the neck, and with sleeves of the same extending to the wrists. Low-necked sleeveless tunic of soft white woolen fabric, (or linen or silk,) fastened on the shoulder, and held in to the figure by a silk sash or girdle. Trousers of white wool, silk or limen, and white linen shoes. White gauze wound about the head in turban style.

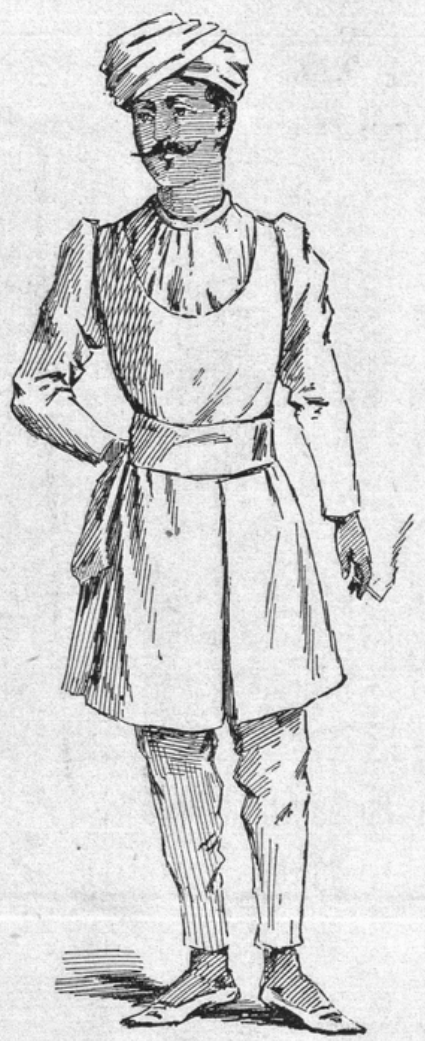

Figure No. 25.-ORIENTAL COSTUME.

Figure No. 26.-East Indian Costume.-This costume is white and gold in its colorings, and the composing materials are soft white wool and silk, and gold embroidery, rope and ornaments. The

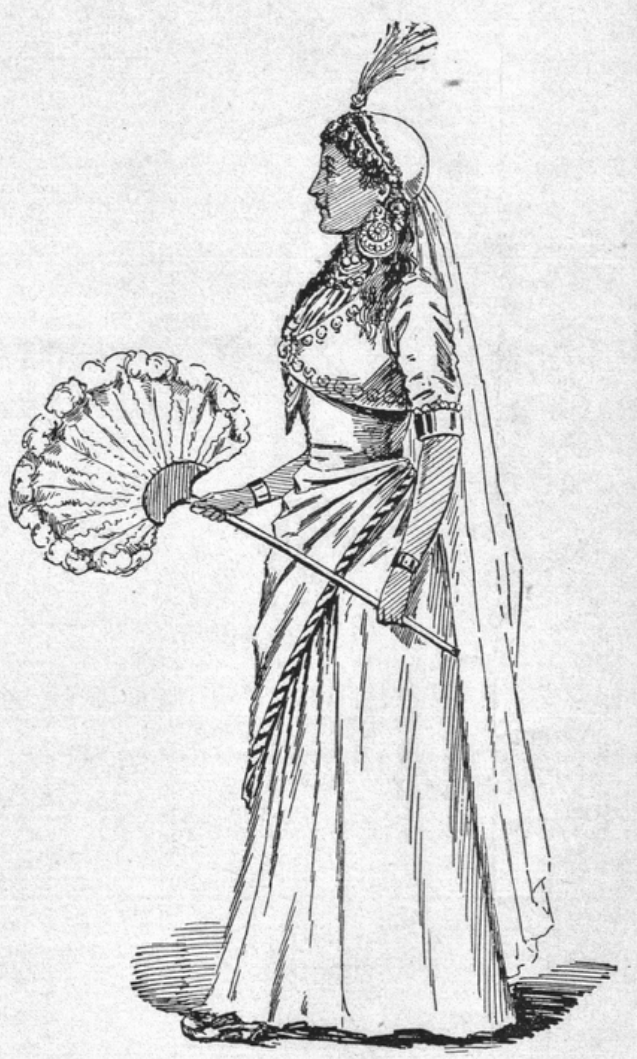

Figure No. 26.-EAST INDIAN COSTUME.

attached to the cap, and the white feather fan has a golden handle. Gold jewelry and golden slippers complete this picturesque costume.

Figure No. 27.-North AMERICAN INDIAN. (For illustration see next page.) - A coat and pair of trousers that show some wear may be used for this suit. The trousers display broad pipings of cloth at the sides, the coat is decorated with colored beads, a brass armlet is worn above the elbow, and a necklace of wolf's teeth encircles the neck. About the waist is a belt or sash, in which are

Figure 14. Page from the book Masquerade and Carnival, depicting "Oriental" Costumes, 1892. The Butterick Publishing Company Limited. Courtesy of the McCord Museum. 
the tomahawk, scalping-knife and other weapons. to form fringe and the fancy decorations are A wig of long, coarse black hair is worn, added above it. A wolf skin hangs from the and the huge Indian head-dress of feathers shoulders, and a gayly beaded pouch is suspended from the belt. Strings of beads and the teeth of animals are about the neck, and

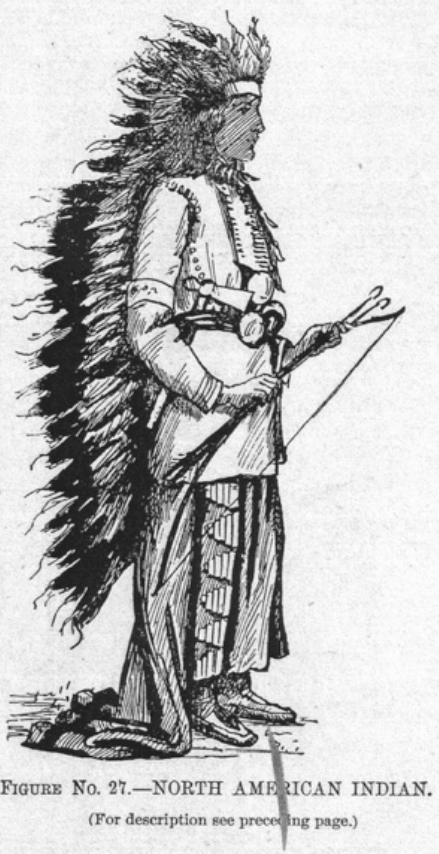

is arranged in characteristic fashion. A flannel blanket is adjusted at the back to trail far behind, leather moccasins are wo trail far behind, leather moccasins are worn course, the character demands that the face be stained a reddish-brown or copper color; and in addition the eye-brows may be blackened to meet at the center, and the face may be painted beneath the lower eyelids to produce a properly . savage expression.

Figure No. 28.-Pocahontas, - This is a pretty costume for a dark brunette. The foundation material is smooth woolen goods of light leather color, and the decorations may be embroidered or appliquéed upon the fabric, or applied in any manner that will result effectively. Feathers, beads, Turkish bands or colored passementerie may be feather. Fancy stockings decorated to represent
used in decorating the costume. The skirt is not leggings, beaded moccasins, a bow and arrows, hemmed at the bottom, but is cut in narrow strips

and a tomahawk complete the costume.

Figure 15. Page from the book Masquerade and Carnival, depicting "North American Indian" and "Pocahontas" Costumes, 1892. The Butterick Publishing Company Limited. Courtesy of the McCord Museum. 


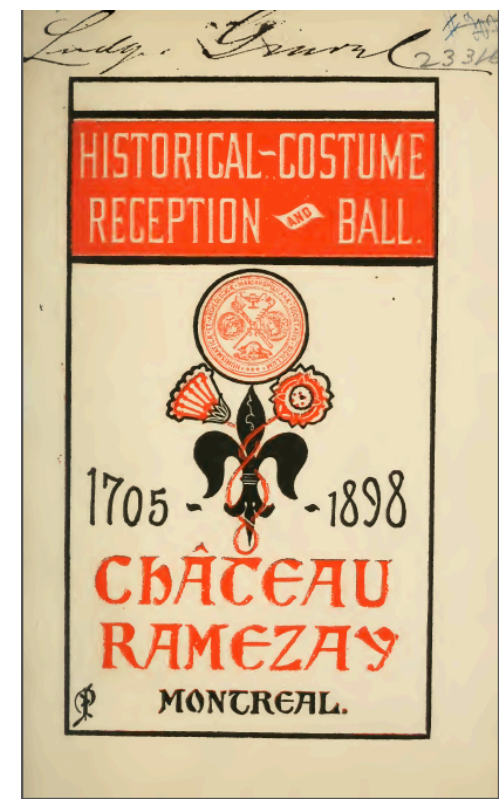

Figure 16. Cover of invitation to the "Historical Costume Reception and Ball" for the Chateau Ramezay, Montreal, QC, 1898. Courtesy of the McCord Museum.

\begin{tabular}{|c|c|}
\hline 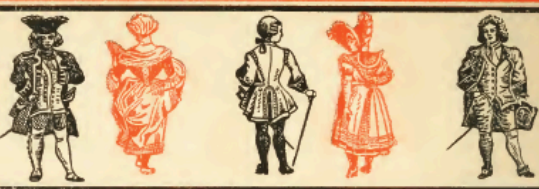 & (a) \\
\hline 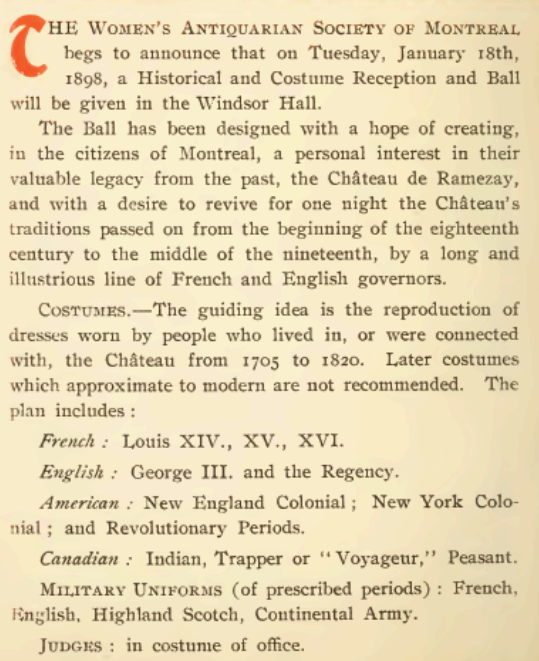 & $\begin{array}{l}\text { While historical costumes are strongly recommended, } \\
\text { ladies and gentlemen who do not desire to appear in such, } \\
\text { may appear in "poudre," and militia officers in uniform. } \\
\text { ADDIrionaL. - Representations of persons notable in } \\
\text { Canadian history, resident in France, Canada or Acadia } \\
\text { from the discovery ( } 1535 \text { ) to } 1820 \text {. } \\
\text { Arrangements will be made for illustrating the history } \\
\text { of Canada by groups made up of distinguished people with } \\
\text { their families and retinues. } \\
\text { Anyone wishing to form a historical group or take } \\
\text { part in one, or to represent any of the admissible historical } \\
\text { characters, is requested to send name and address to } \\
\text { Ball Committee. } \\
\text { As limitations of space compel the limitation of the } \\
\text { number of guests, intending subscribers are requested to } \\
\text { make an early application for tickets and, if convenient, to } \\
\text { indicate their proposed costume. } \\
\text { A limited number of spectators' tickets, for the galleries, } \\
\text { may be had at } \$ 3 \text { and } \$ 2 \text { each. } \\
\text { Information about ladies' costumes may be obtained } \\
\text { by written application to the convener of the Costume } \\
\text { Committee, Mrs. C. E. SPRAGGr, } 13 \mathrm{I} \text { Durocher street. } \\
\text { Accurate costumes for gentlemen will be made and } \\
\text { hired, at very reasonable prices, by Mr. R. Beullac, costu- } \\
\text { mer, I } 617 \text { Notre-Dame street. }\end{array}$ \\
\hline
\end{tabular}

Figure 17. Page from the invitation to the "Historical Costume Reception and Ball" for the Chateau Ramezay, Montreal, QC, 1898. Courtesy of the McCord Museum. 


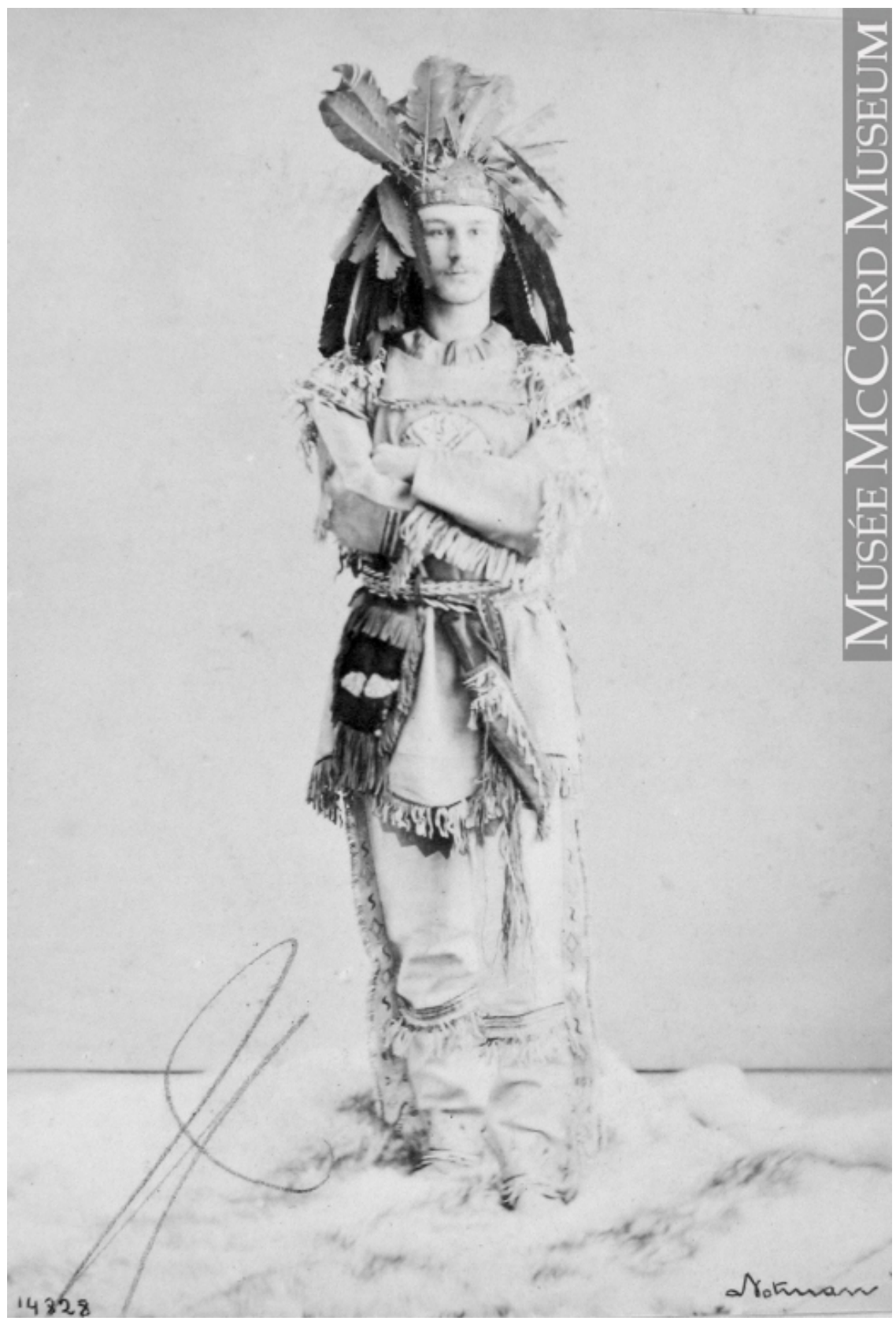

Figure 18. Charles Bouthillier in "Indian" costume, Montreal, QC, 1865. William Notman. Albumen print mounted on paper. Notman Photographic Archives at the McCord Museum. 


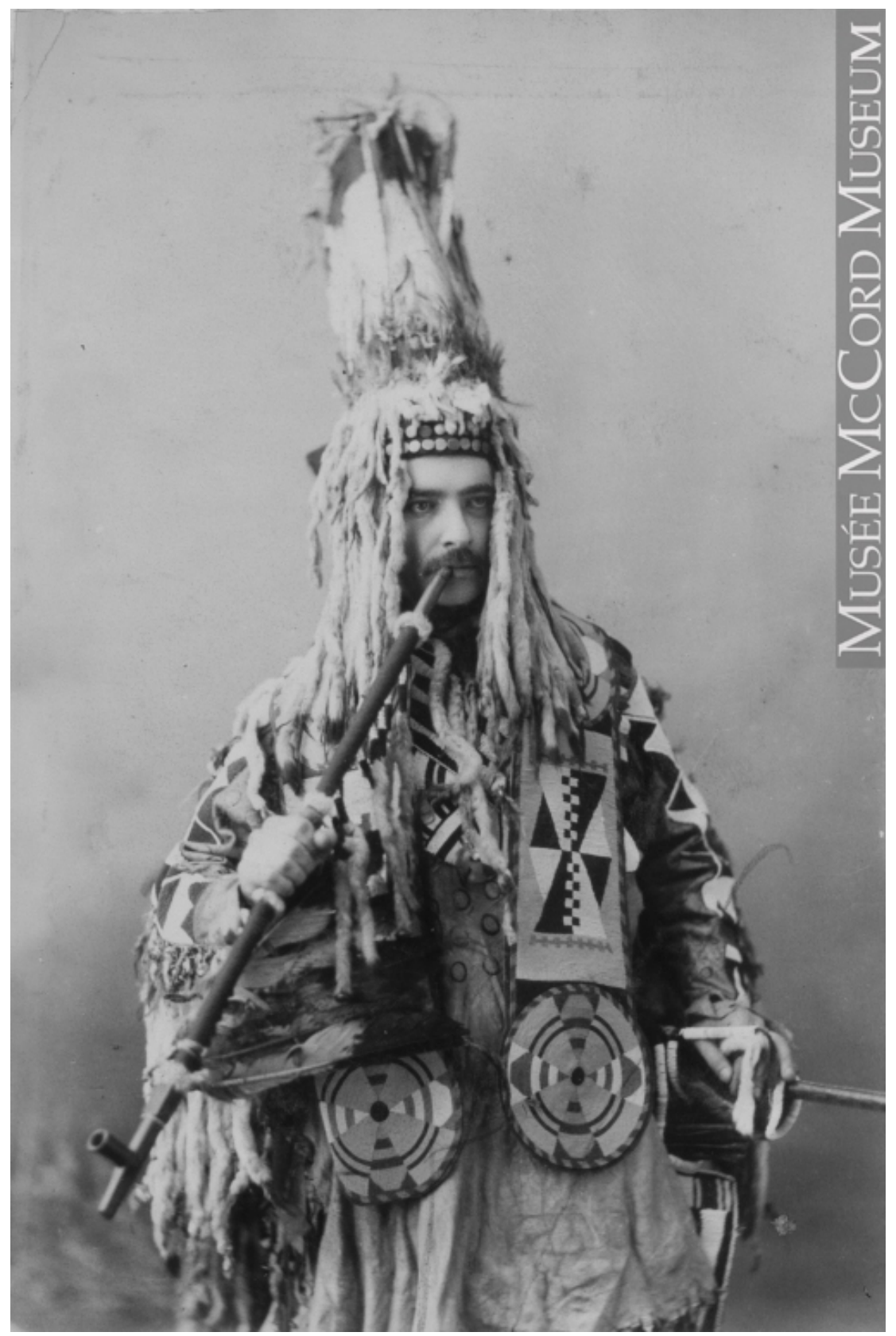

Figure 19. Mr. Wright in "Indian" costume, Montreal, QC, 1881. Notman \& Sandham. Albumen print mounted on paper. Notman Photographic Archives at the McCord Museum. 


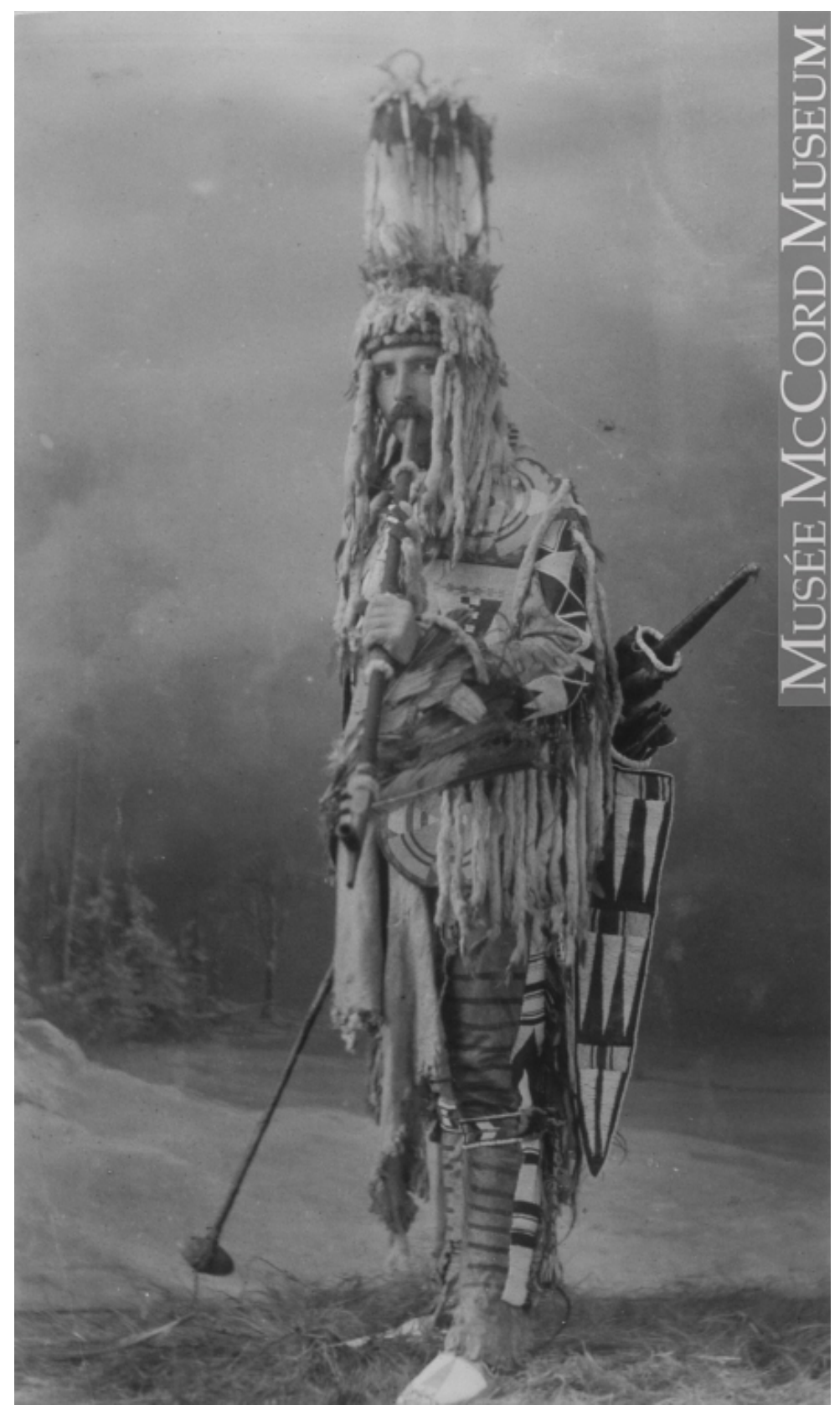

Figure 20. F.A. Wise in "Indian" costume, Montreal, QC, 1881. Notman \& Sandham. Albumen print mounted on paper. Notman Photographic Archives at the McCord Museum. 


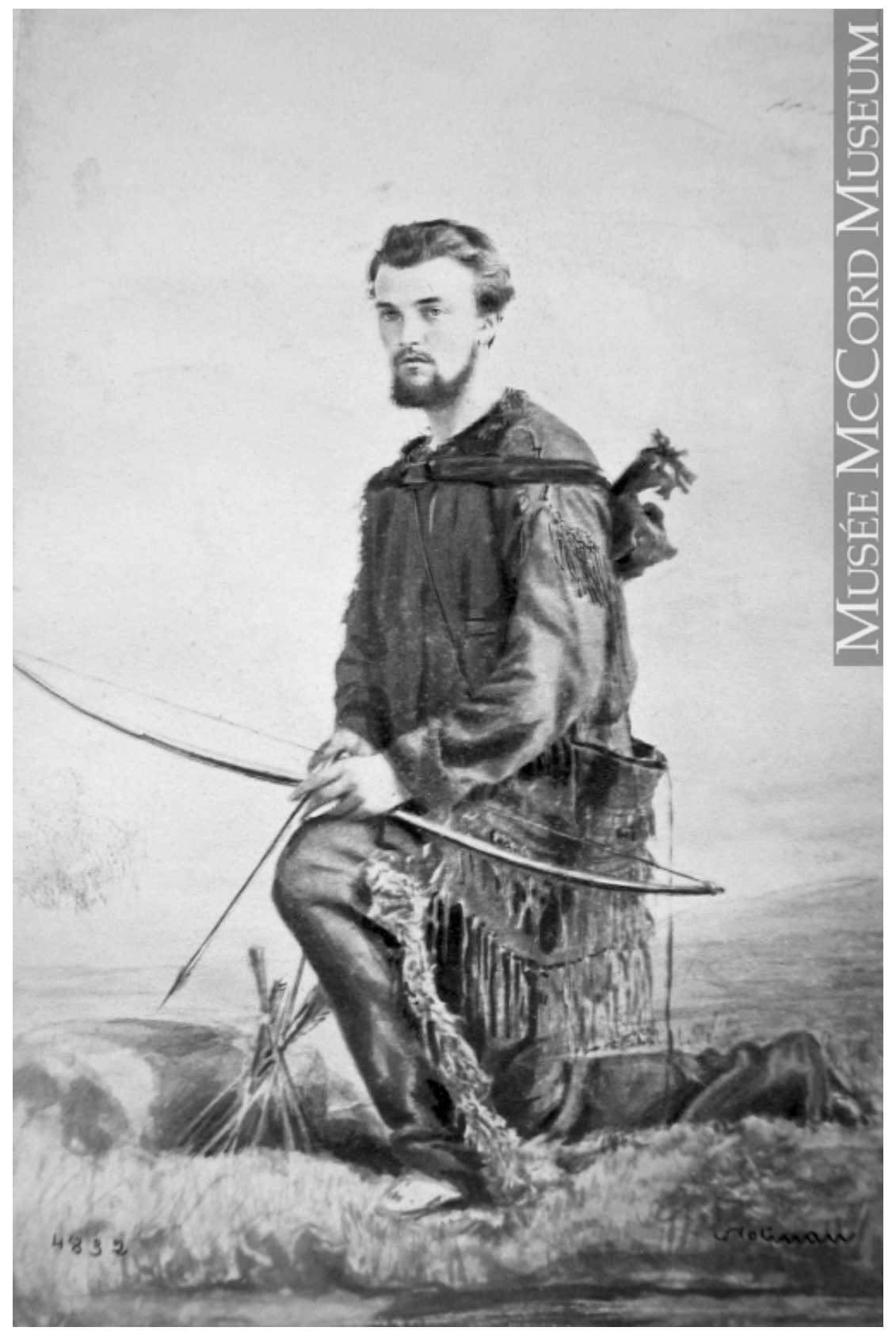

Figure 21. Lord Dunmore in "Indian" costume, painted photograph, 1862. William Notman. Albumen print mounted on paper. Notman Photographic Archives at the McCord Museum. 


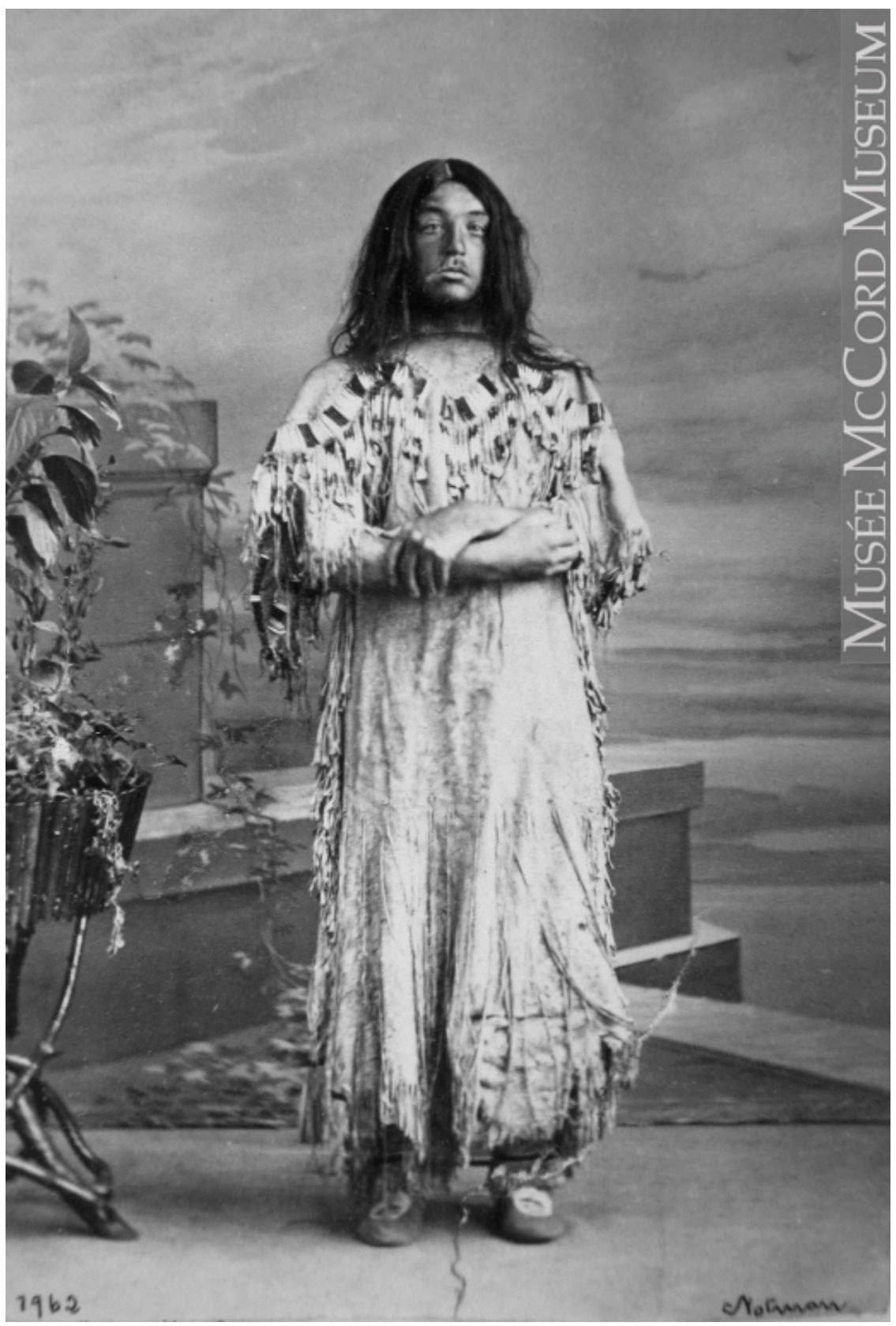

Figure 22. Mr. Jefferson, $16^{\text {th }}$ Regiment, in costume, Montreal, QC, 1863. William Notman. Albumen print mounted on paper. Notman Photographic Archives at the McCord Museum. 


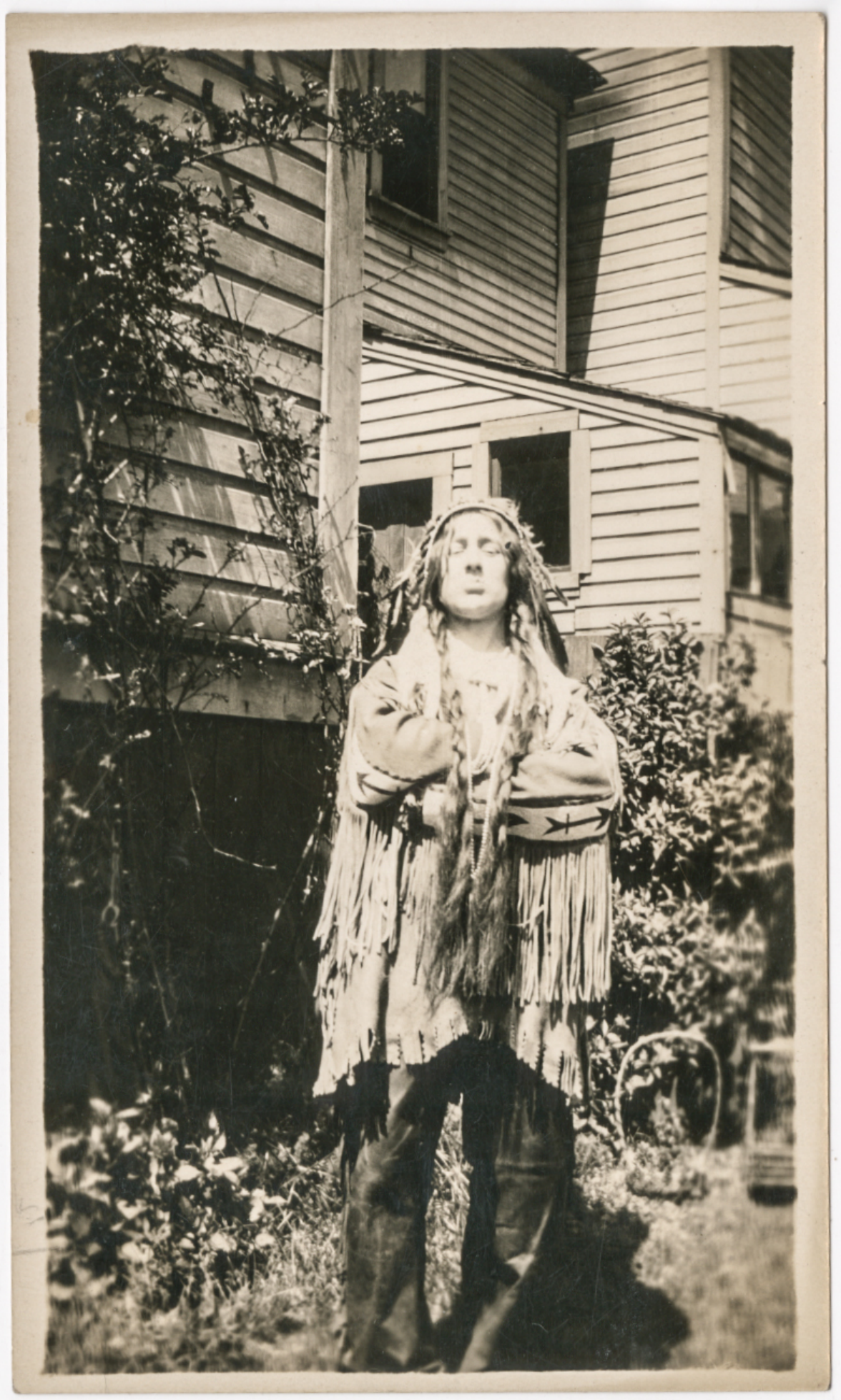

Figure 23. Snapshot portrait of a man in Plains-inspired Native North American costume, $20^{\text {th }}$ century. Gelatin silver print. First Nations Collection at the Archive of Modern Conflict Toronto. 


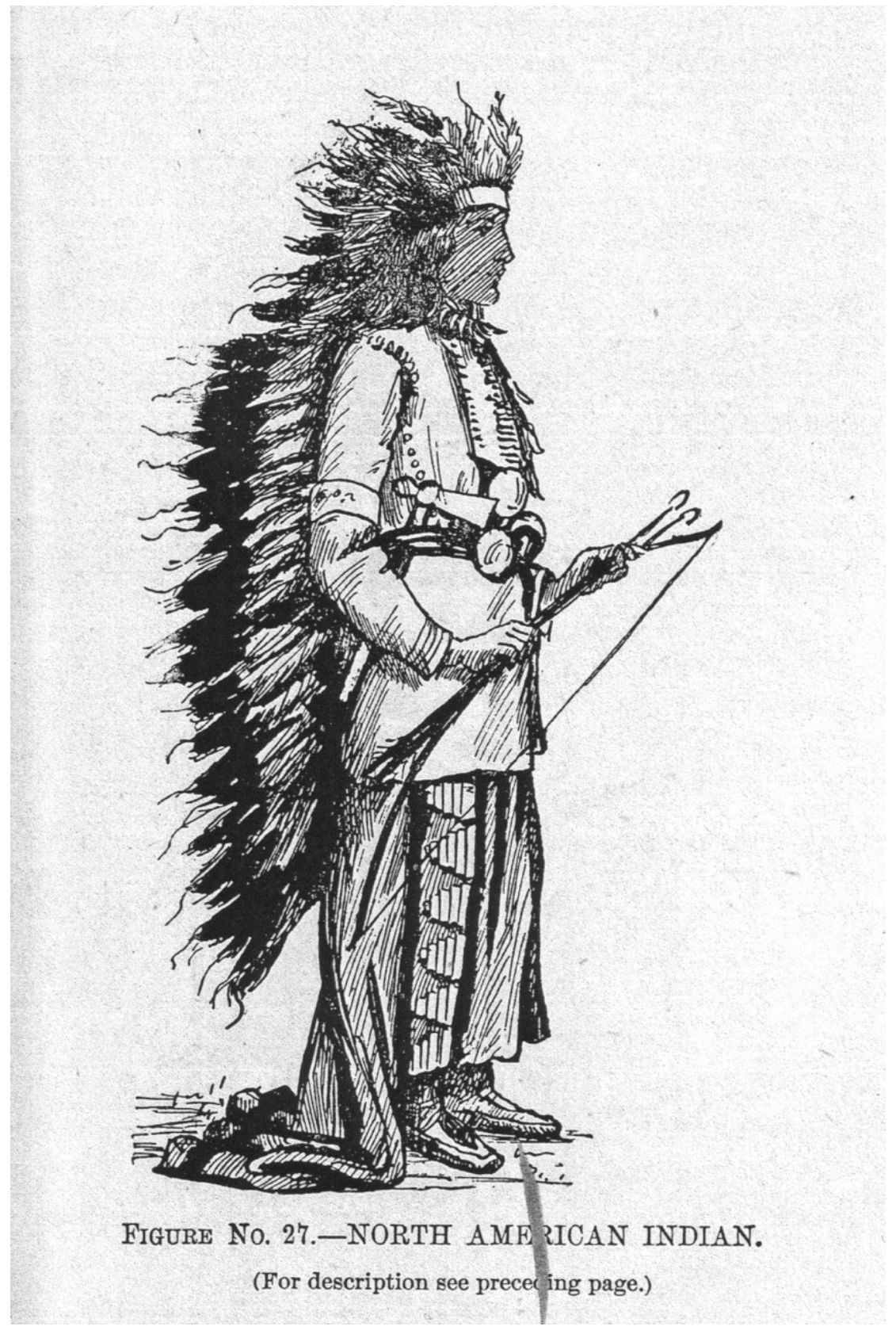

Figure 24. Page from the book Masquerade and Carnival, depicting "North American Indian" costume, 1892. The Butterick Publishing Company Limited. Courtesy of the McCord Museum. 


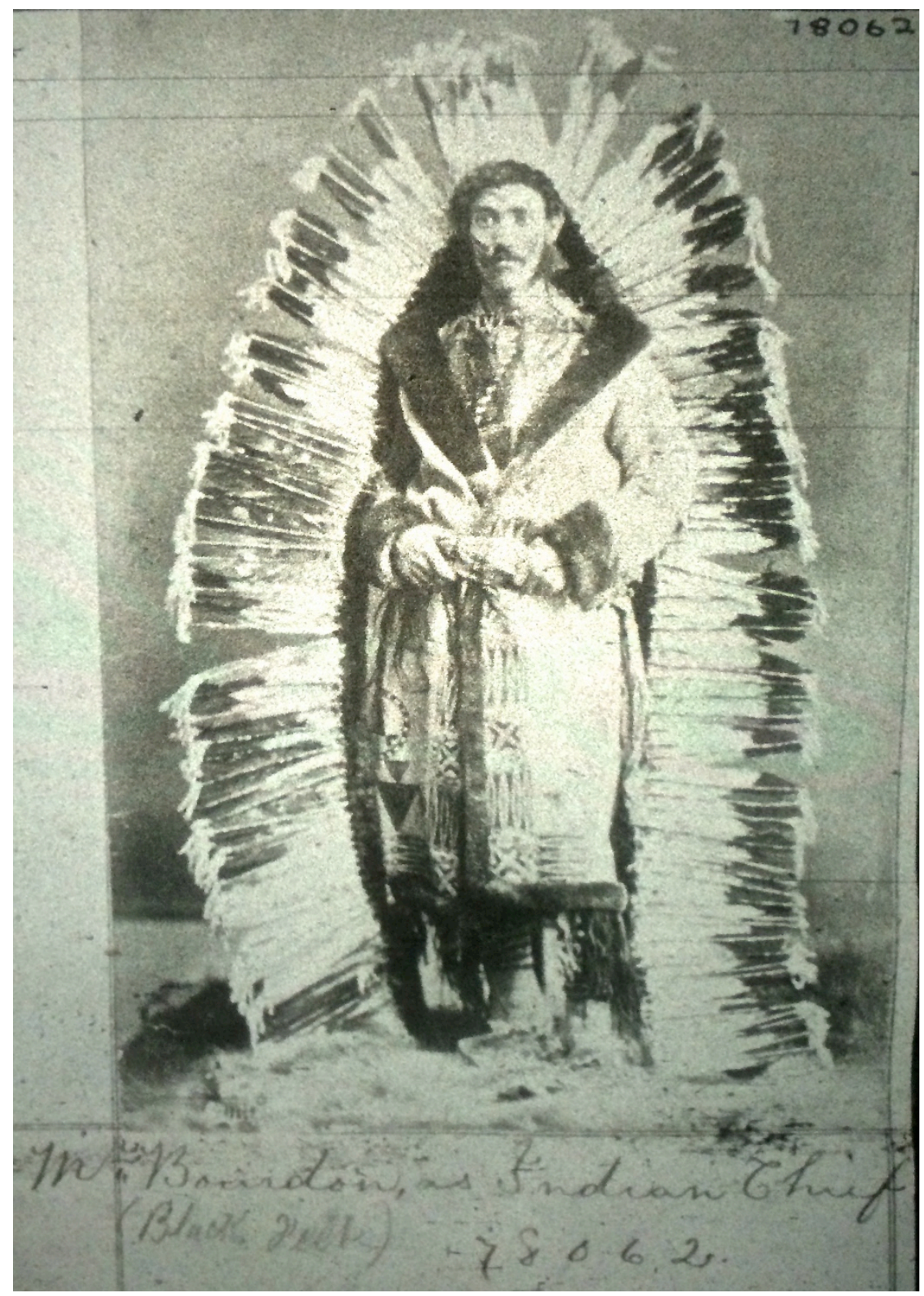

Figure 25. Photograph of microfilm of Mr. Bourdon as "Blackfeet Indian Chief," Montreal, QC, 1872. William Notman. Albumen print mounted on paper. Notman Photographic Archives at the McCord Museum. 


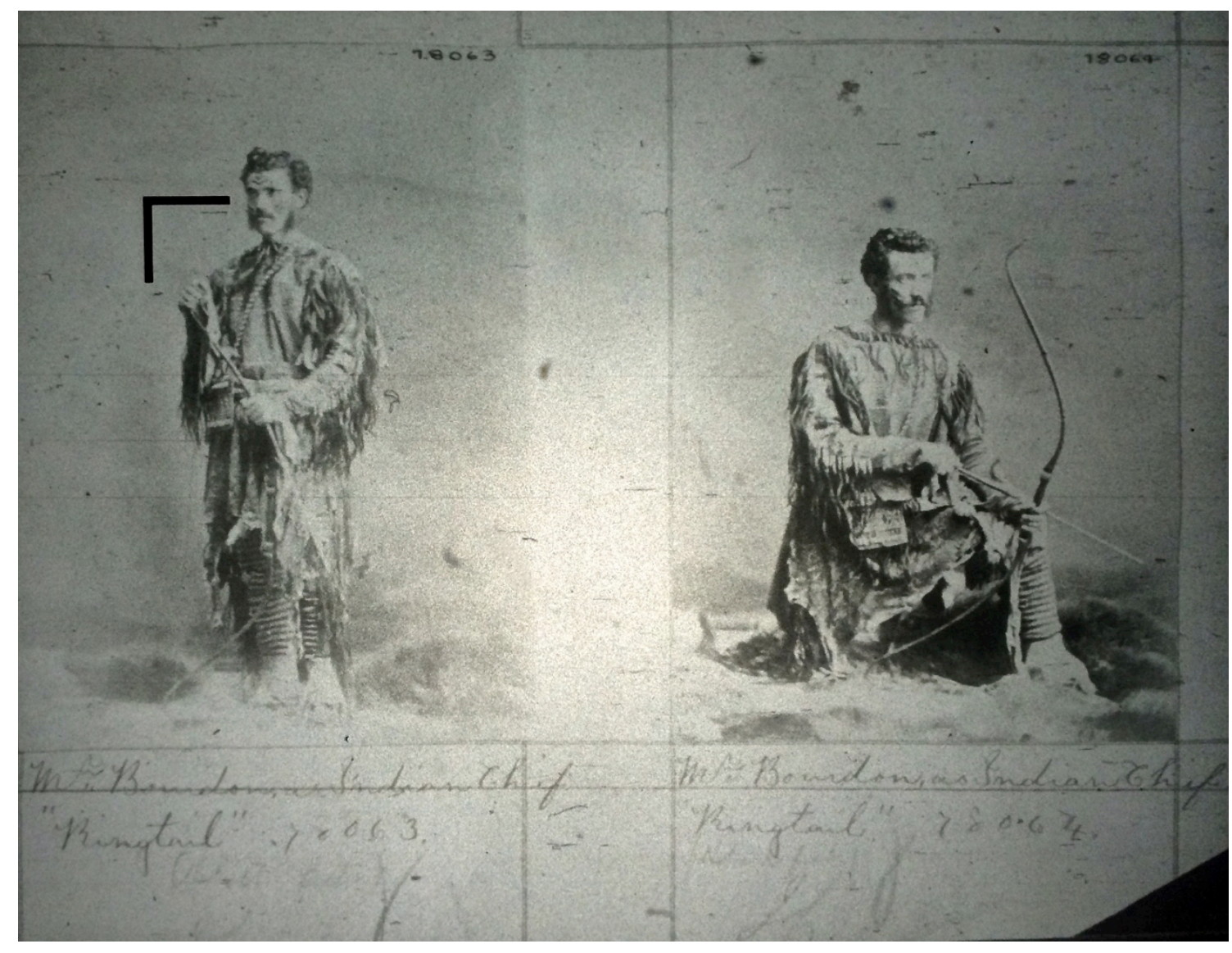

Figure 26. Photograph of microfilm of Mr. Bourdon as "Kingtail Indian Chief," Montreal, QC, 1872. William Notman. Albumen print mounted on paper. Notman Photographic Archives at the McCord Museum. 


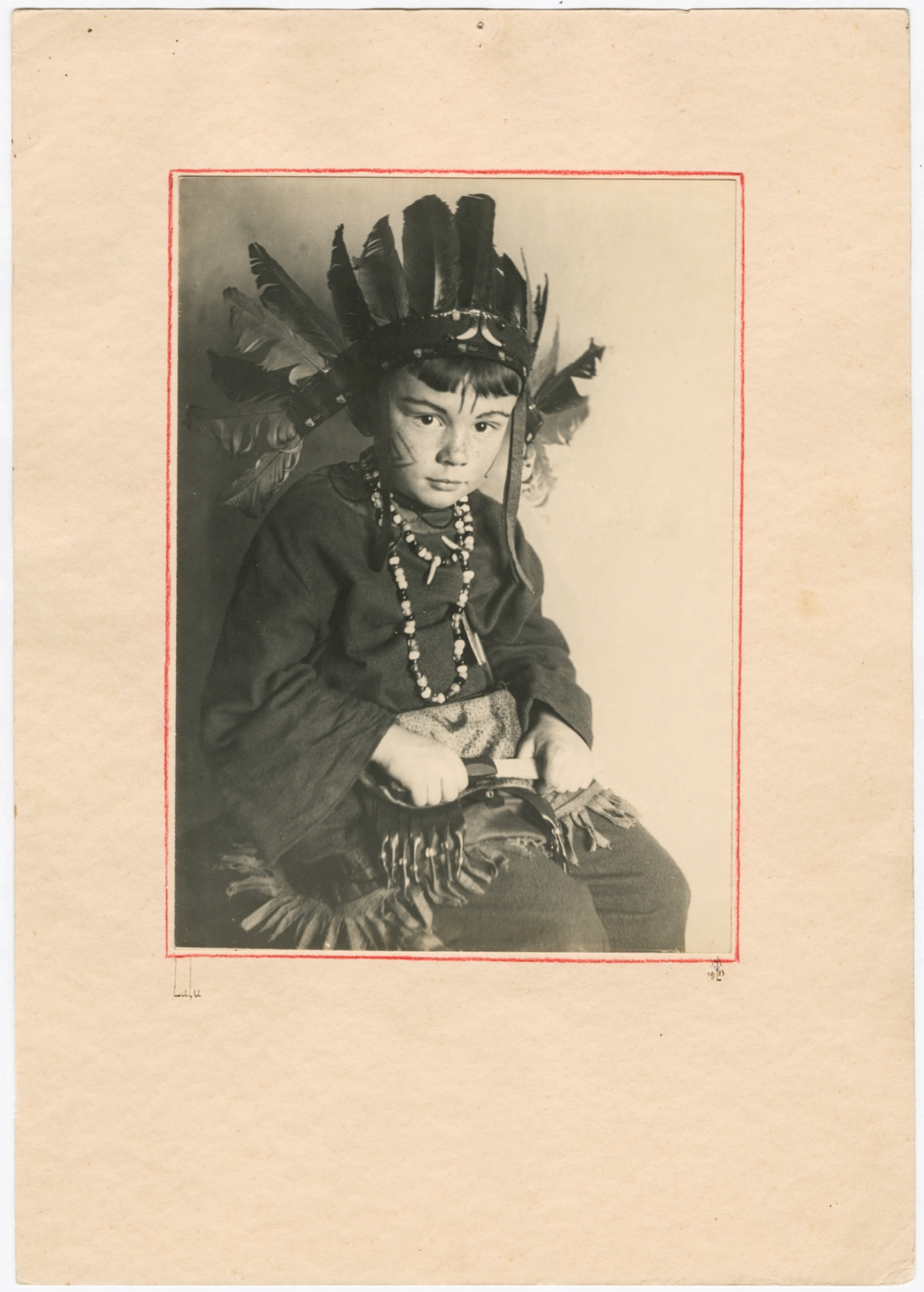

Figure 27. Studio Portrait of a child dressed in Plains-inspired Indian costume with tomahawk and face paint, 1933. Inscription on recto reads: "LuLu." Gelatin silver print on matte paper. First Nations Collection at the Archive of Modern Conflict Toronto. 


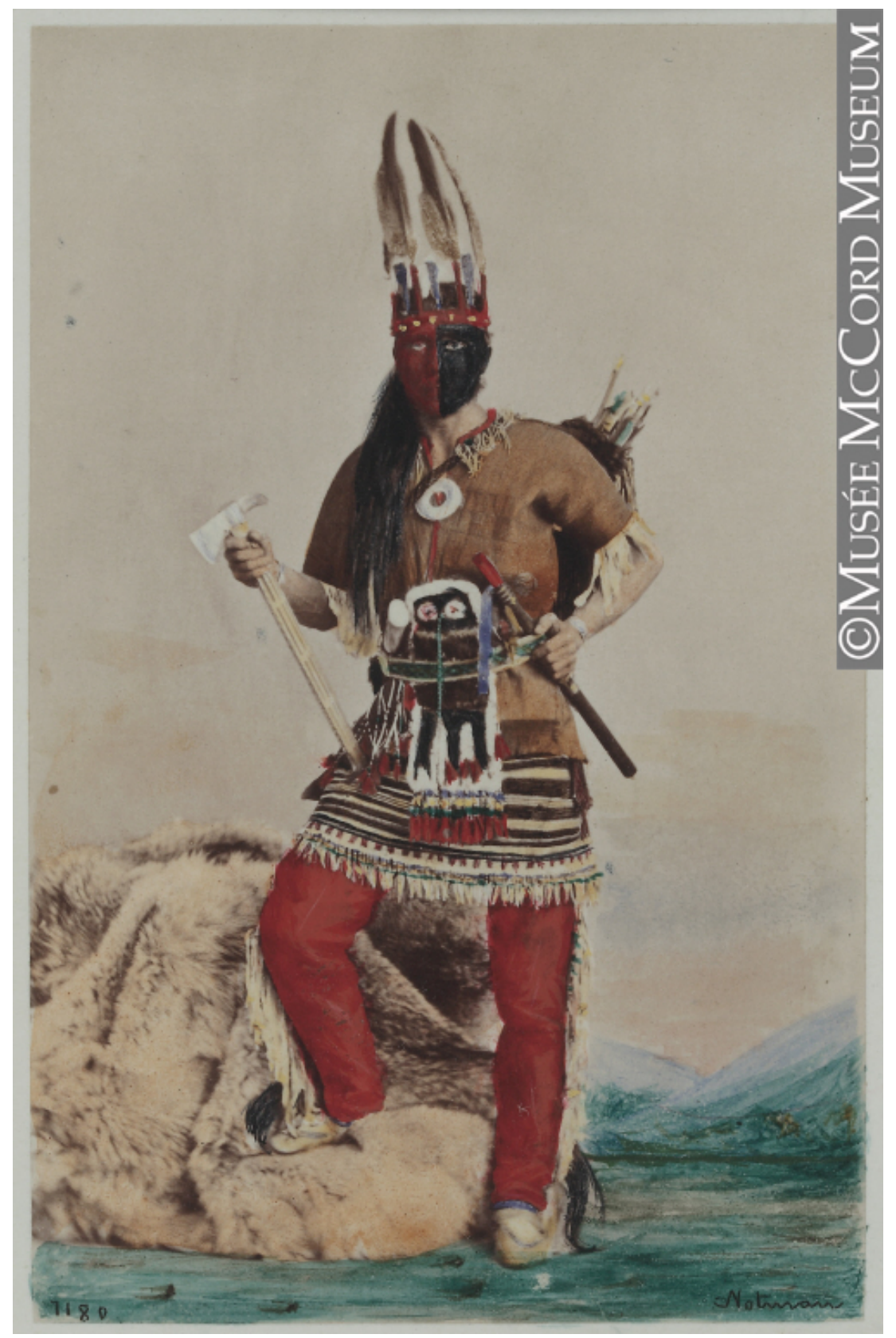

Figure 28. Andrew A. McCulloch costumed as an "Indian, " painted photograph, Montreal, QC, 1863. William Notman and John Arthur Fraser. Albumen print mounted on cardboard, painted with watercolour. Notman Photographic Archives at the McCord Museum. 


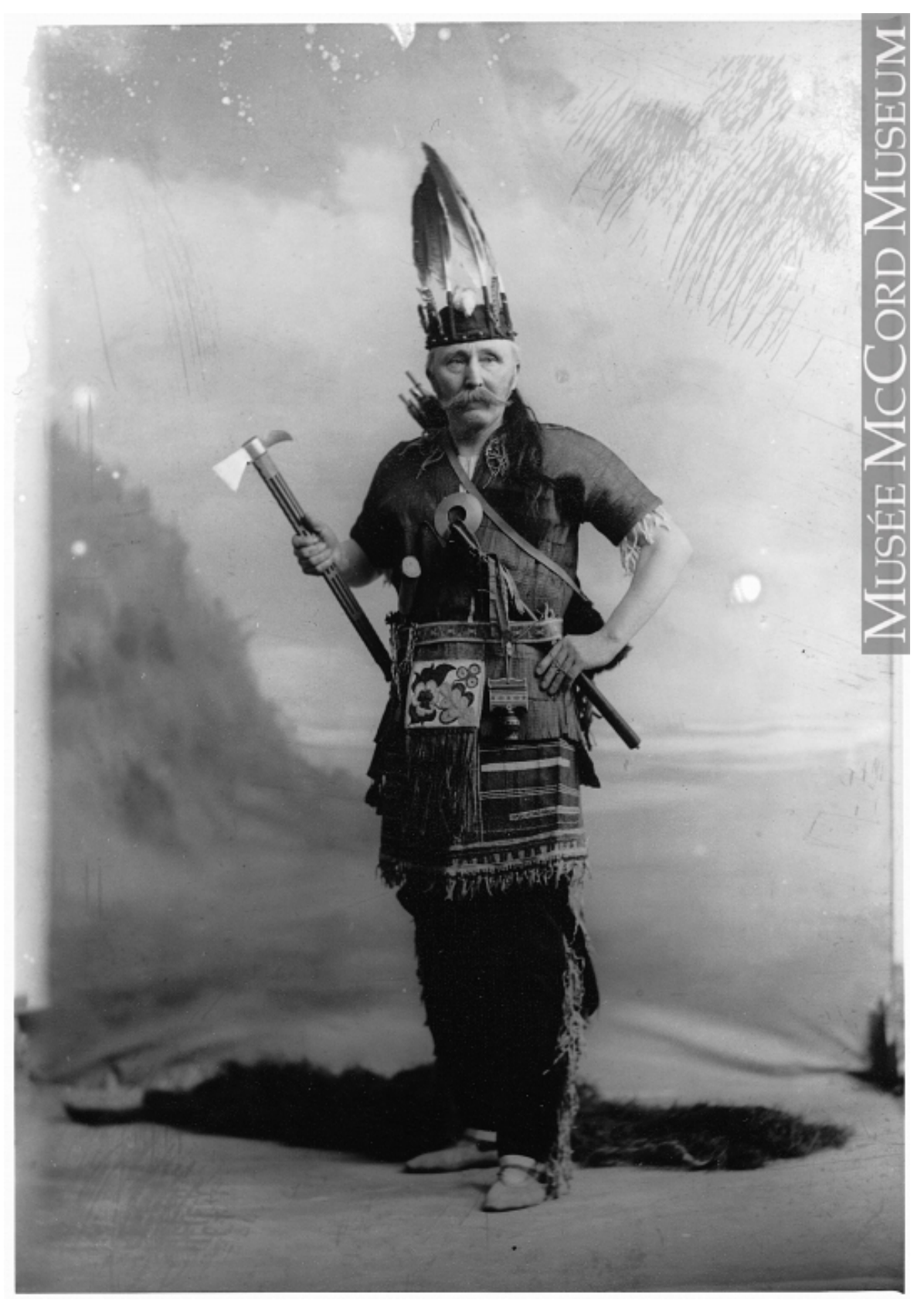

Figure 29. Andrew A. McCulloch, costumed for Chateau de Ramezay Ball, Montreal, QC, 1898. William Notman \& Son. Dry gelatin silver glass plate negative. Notman Photographic Archives at the McCord Museum. 


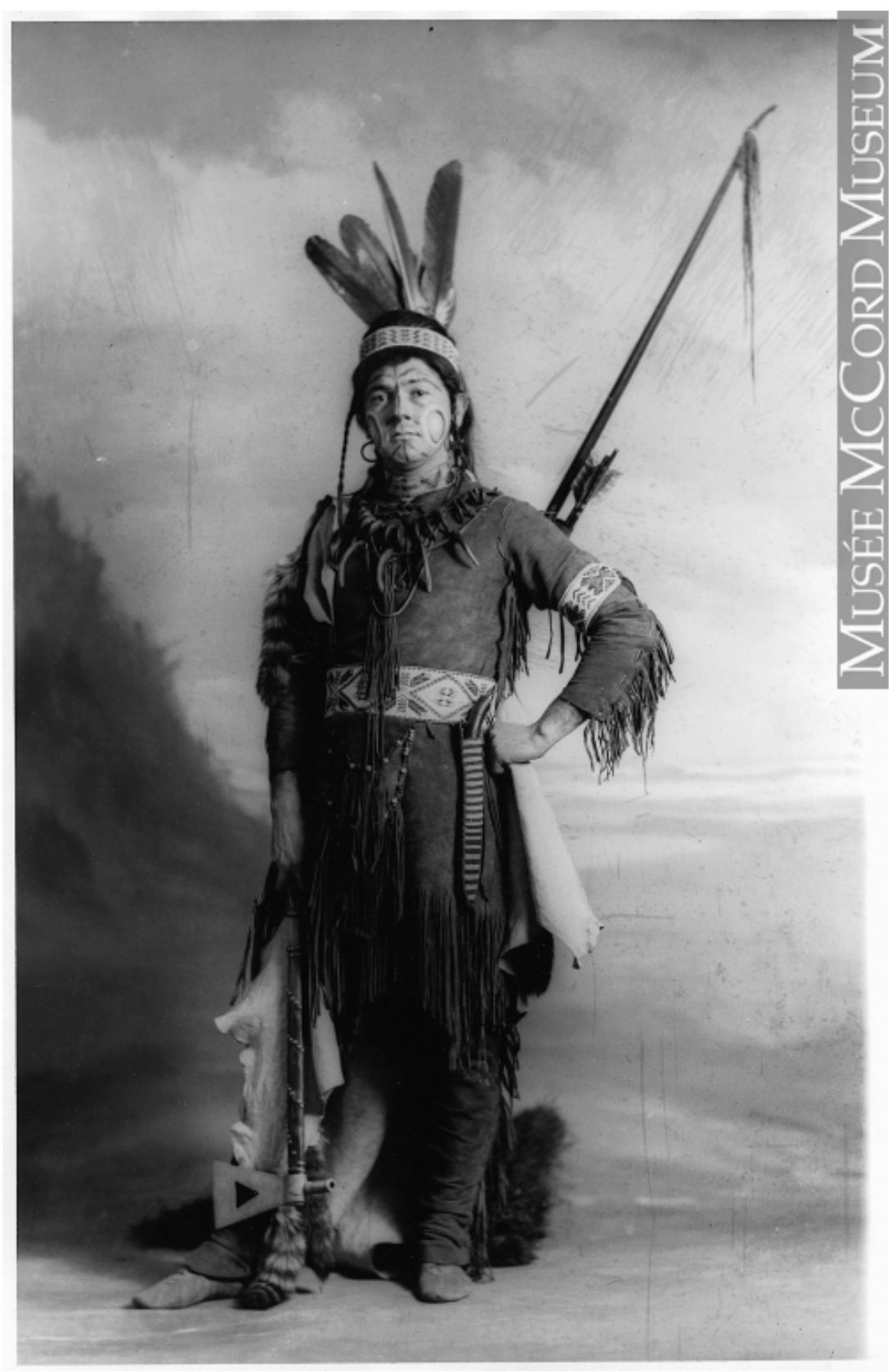

Figure 30. M. de Blois Thibaudeau, costumed for the Chateau de Ramezay Ball, Montreal, QC, 1898. William Notman \& Son. Dry gelatin silver glass plate negative. Notman Photographic Archives at the McCord Museum. 


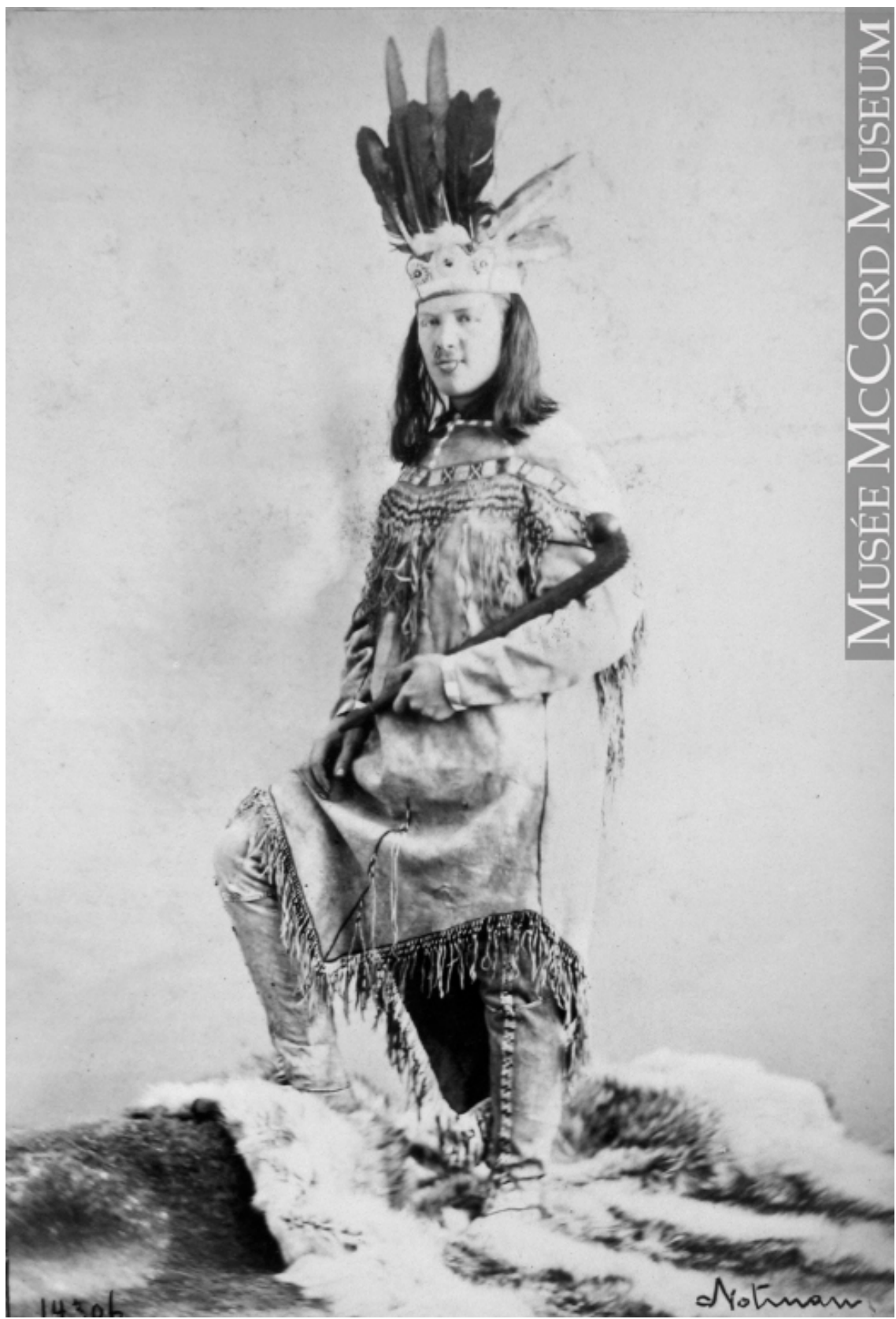

Figure 31. Henry George Vennor in "Indian" costume, Montreal, QC, 1865. William Notman. Albumen print mounted on paper. Notman Photographic Archives at the McCord Museum. 


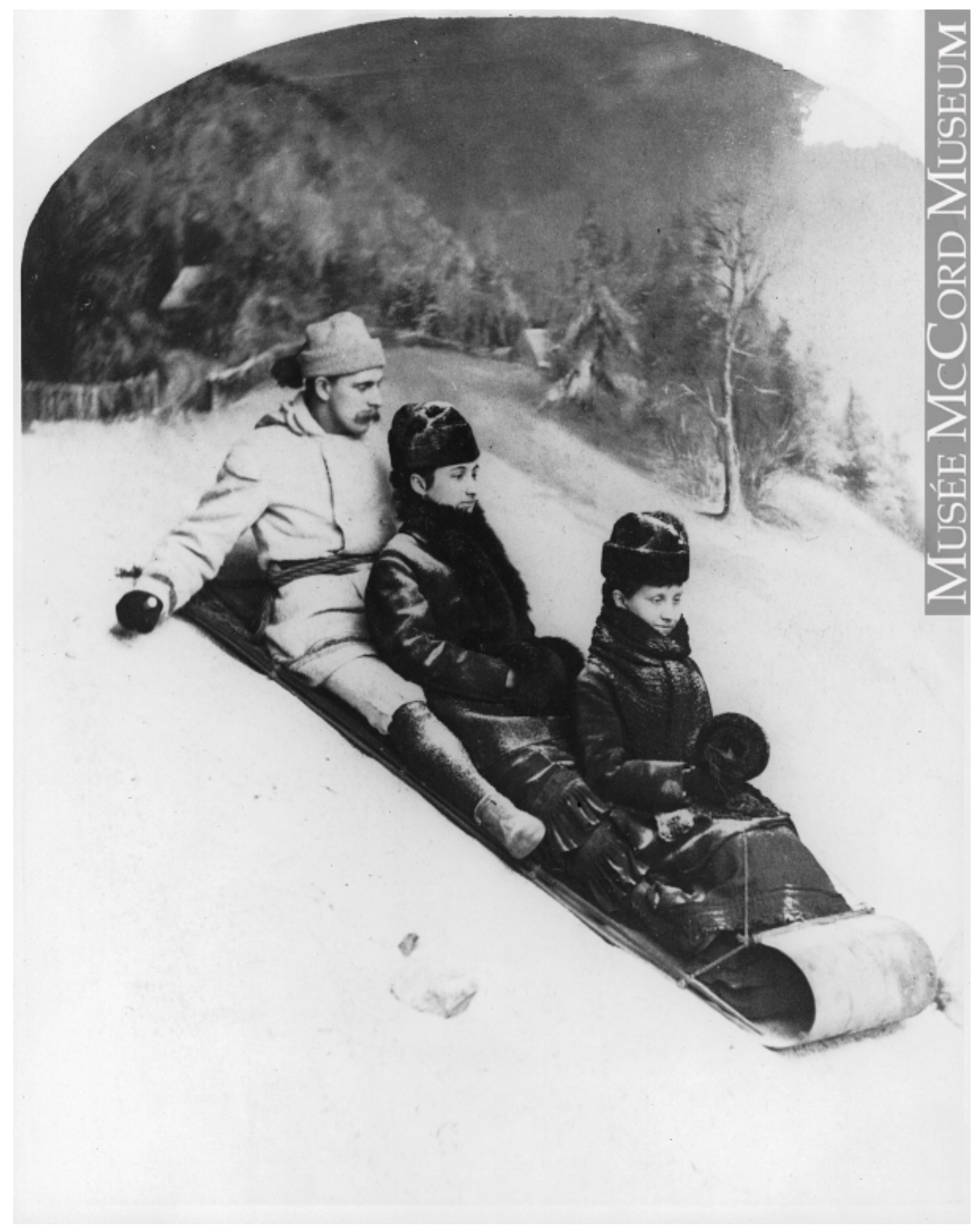

Figure 32. Robert Summerhayes and ladies tobogganing, Montreal, QC, ca.1875. William Notman. Albumen print mounted on paper. Notman Photographic Archives at the McCord Museum. 


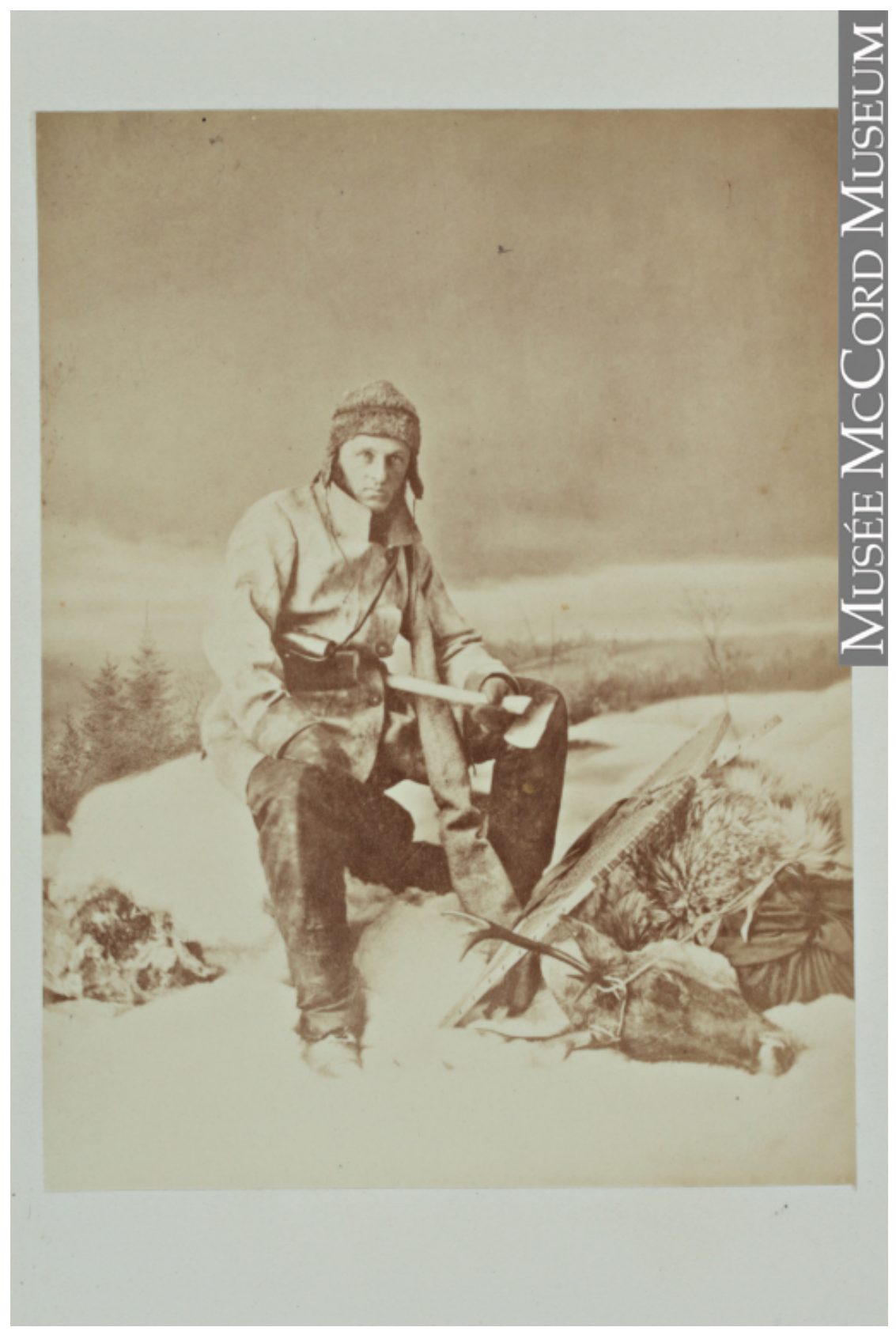

Figure 33. Caribou Hunting, "The Hunter, " Montreal, QC, 1866. William Notman. Albumen print mounted on paper. Notman Photographic Archives at the McCord Museum. 


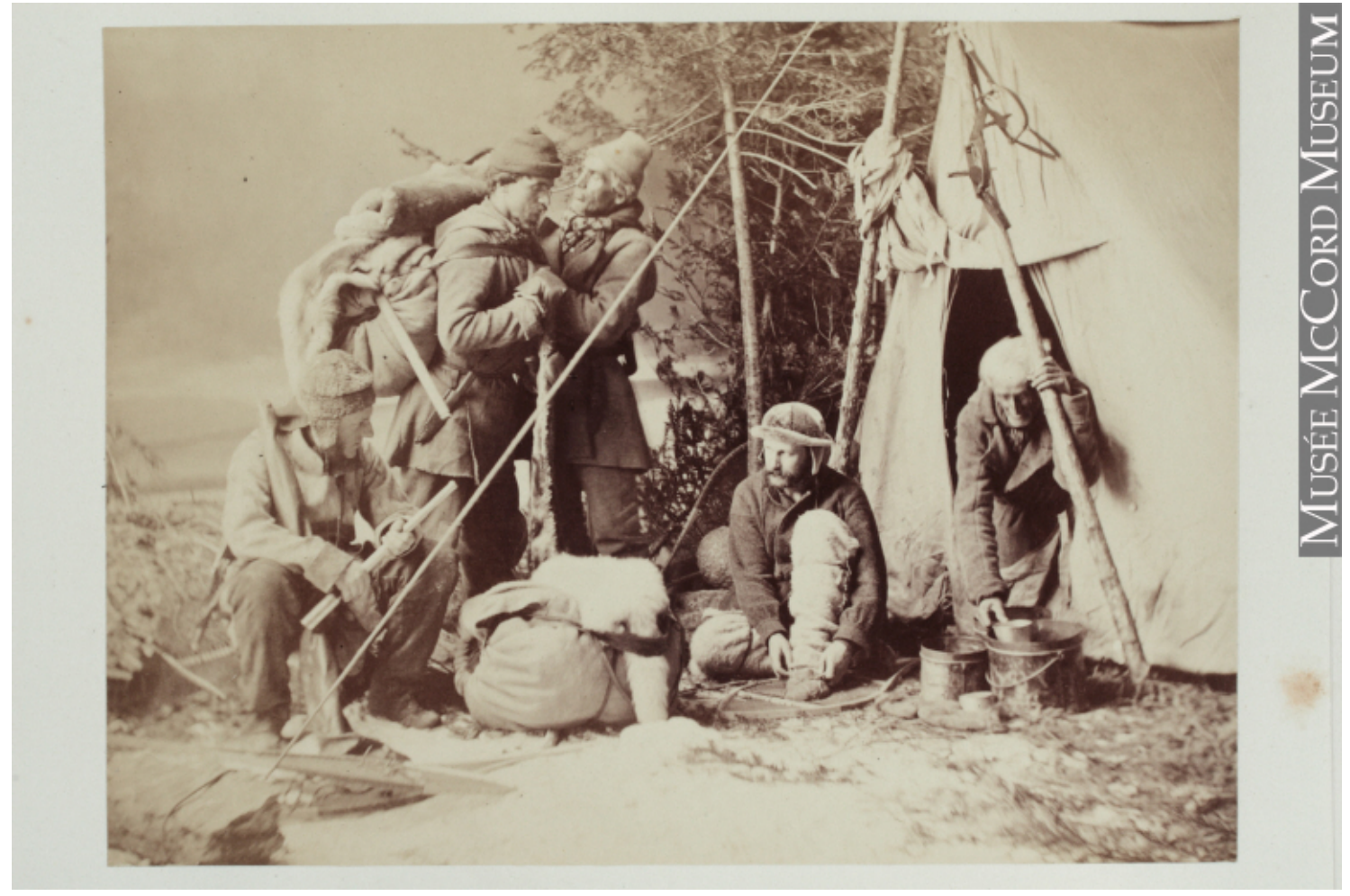

Figure 34. Caribou Hunting, “Arrival at Camp," Montreal, QC, 1866. William Notman. Albumen print mounted on paper. Notman Photographic Archives at the McCord Museum. 


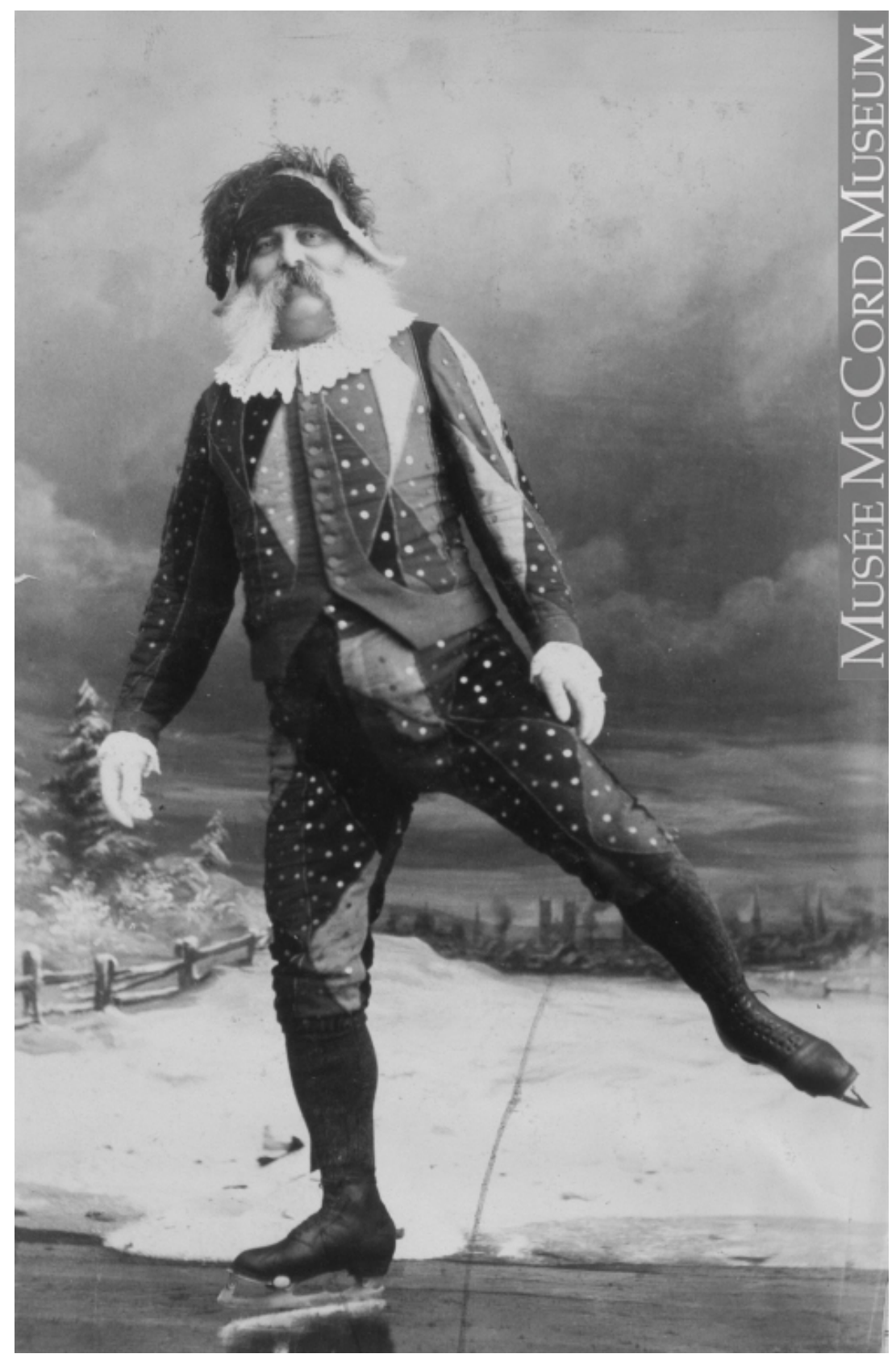

Figure 35. A.G. Lord in skating party costume, posed for a composite, Montreal, QC, 1881. Notman \& Sandham. Albumen print mounted on paper. Notman Photographic Archives at the McCord Museum. 


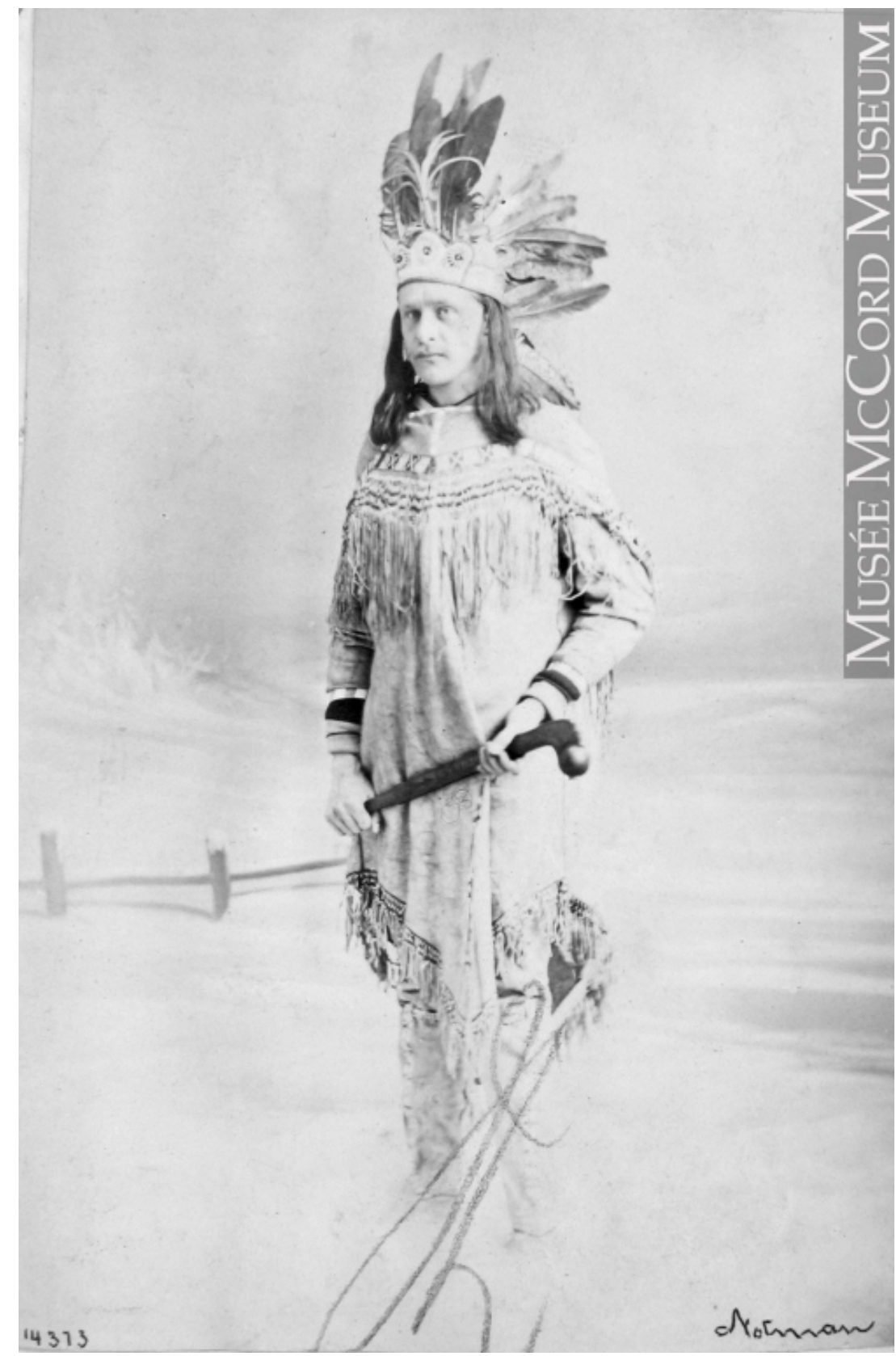

Figure 36. William George Beers in "Indian" costume, Montreal, QC, 1865. William Notman. Albumen print mounted on paper. Notman Photographic Archives at the McCord Museum. 


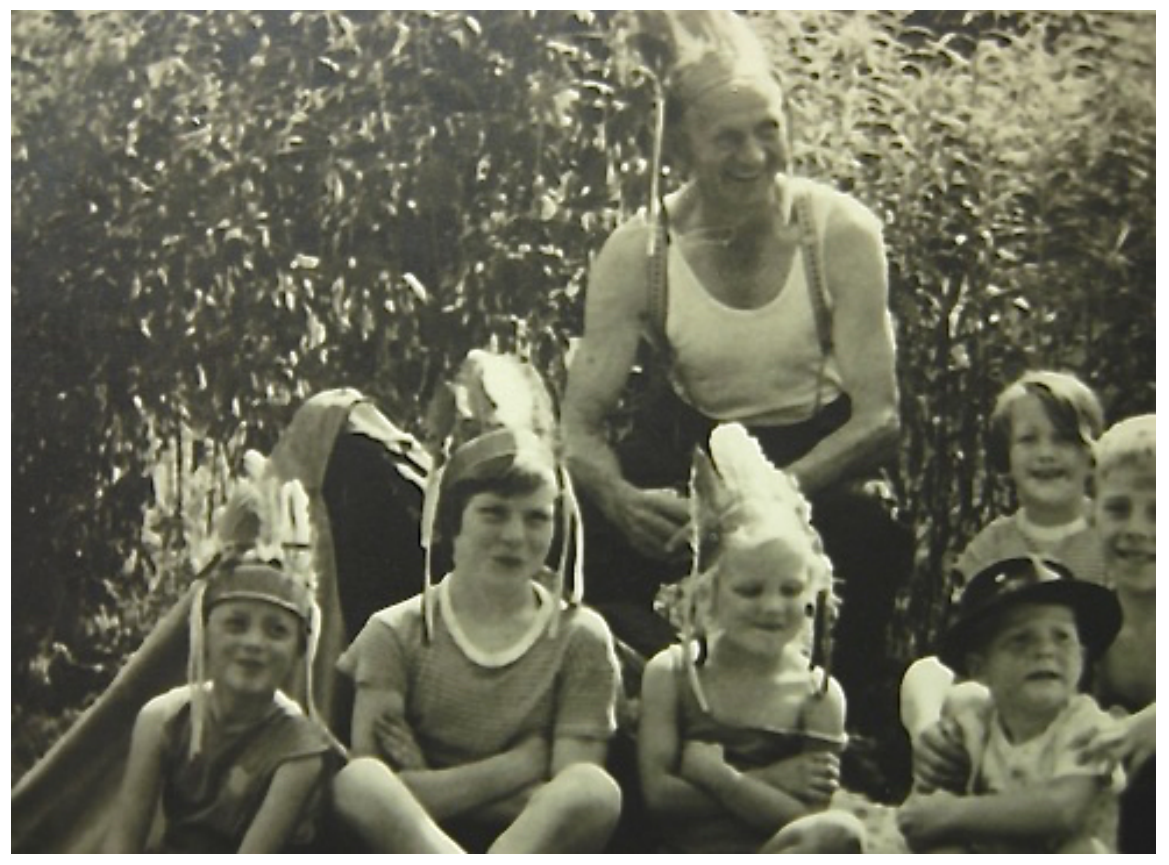

Figure 37. Family photograph of adult and children "playing Indian," ca.1950. Unknown photographer. Gelatin silver print. Personal Collection.

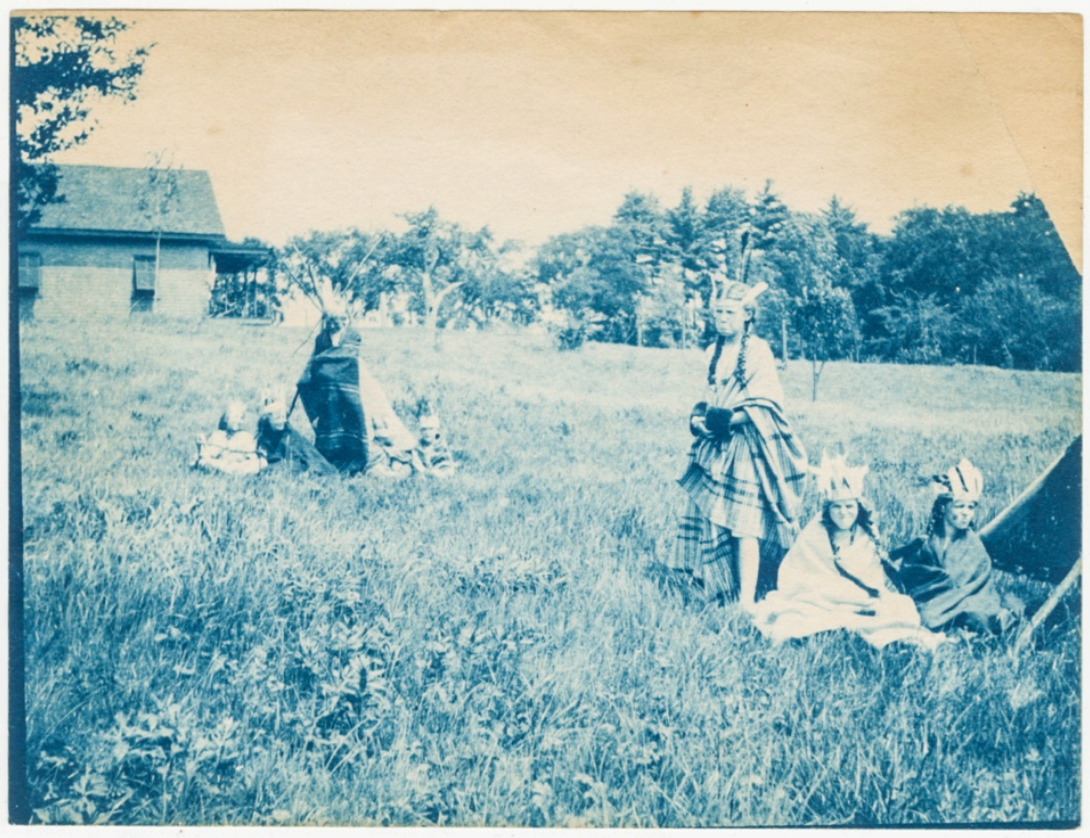

Figure 38. Children in costume "playing Indian" out in a field with teepees, late $19^{\text {th }}$ to early $20^{\text {th }}$ century. Cyanotype photograph on fiber paper. First Nations Collection at the Archive of Modern Conflict Toronto. 


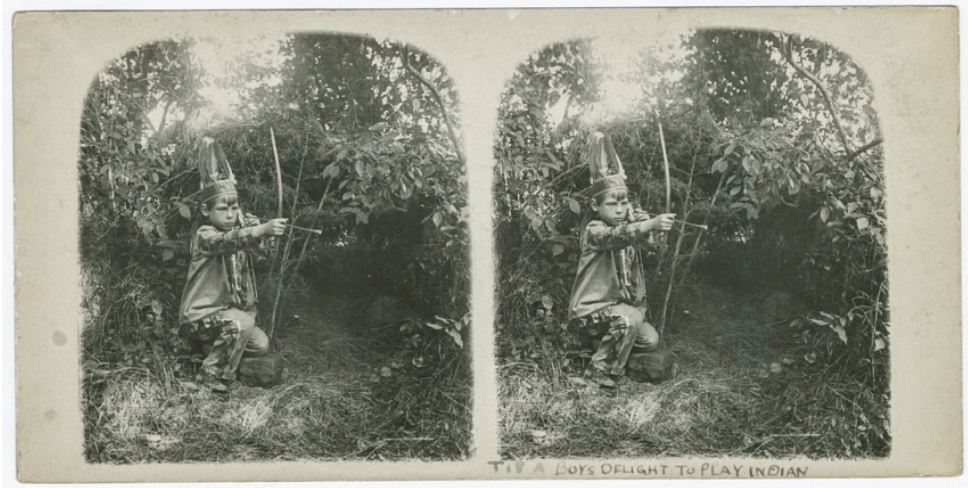

Figure 39. Stereocard of a young boy in costume "playing Indian" kneeling with a bow and arrow. Inscription on recto reads: "Tis a boys delight to play Indian," late $19^{\text {th }}$ century. Gelatin silver print on card. First Nations Collection at the Archive of Modern Conflict Toronto.

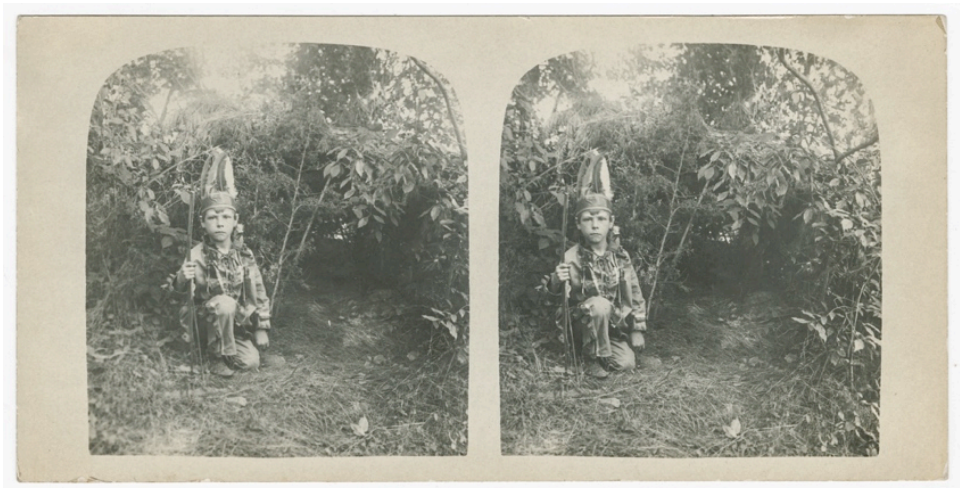

Figure 40. Stereocard of a young boy in costume "playing Indian" kneeling and facing the camera, late $19^{\text {th }}$ century. Gelatin silver print on card. First Nations Collection at the Archive of Modern Conflict Toronto.

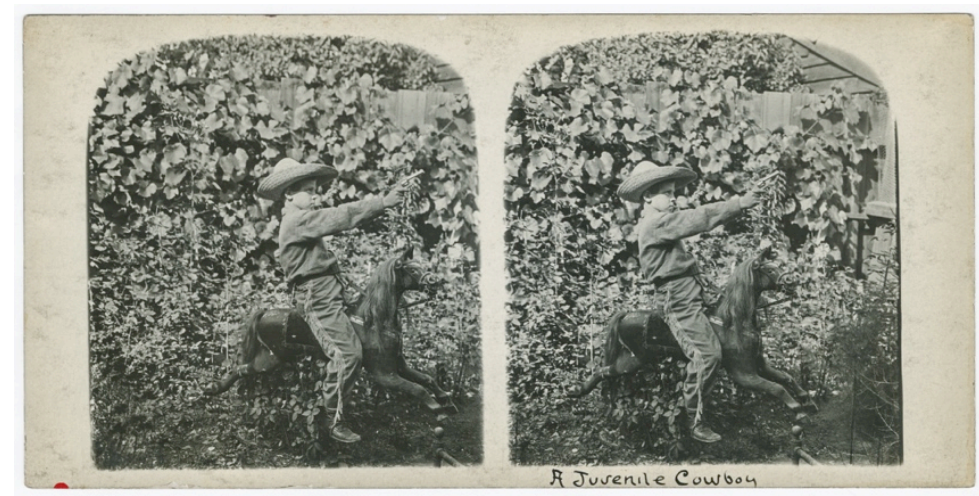

Figure 41. Stereocard of a young boy in cowboy costume riding a toy horse., Inscription on recto reads: “A Juvenile Cowboy," late $19^{\text {th }}$ century. Gelatin silver print on card. First Nations Collection at the Archive of Modern Conflict Toronto. 


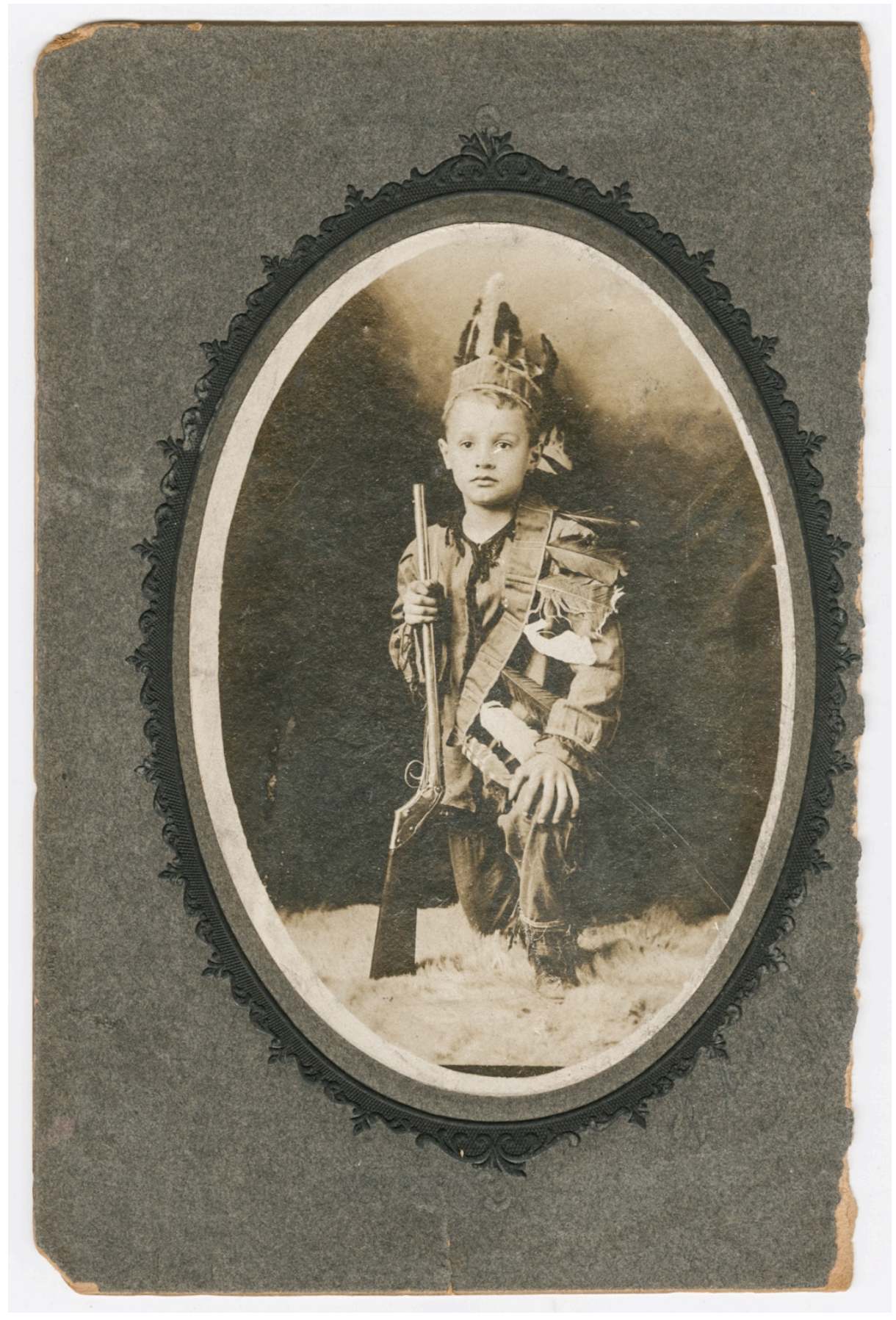

Figure 42. Studio portrait of a young boy dressed in "Indian" costume, kneeling and holding a rifle, late $19^{\text {th }}$ century. Albumen print mounted on card. First Nations Collection at the Archive of Modern Conflict Toronto. 


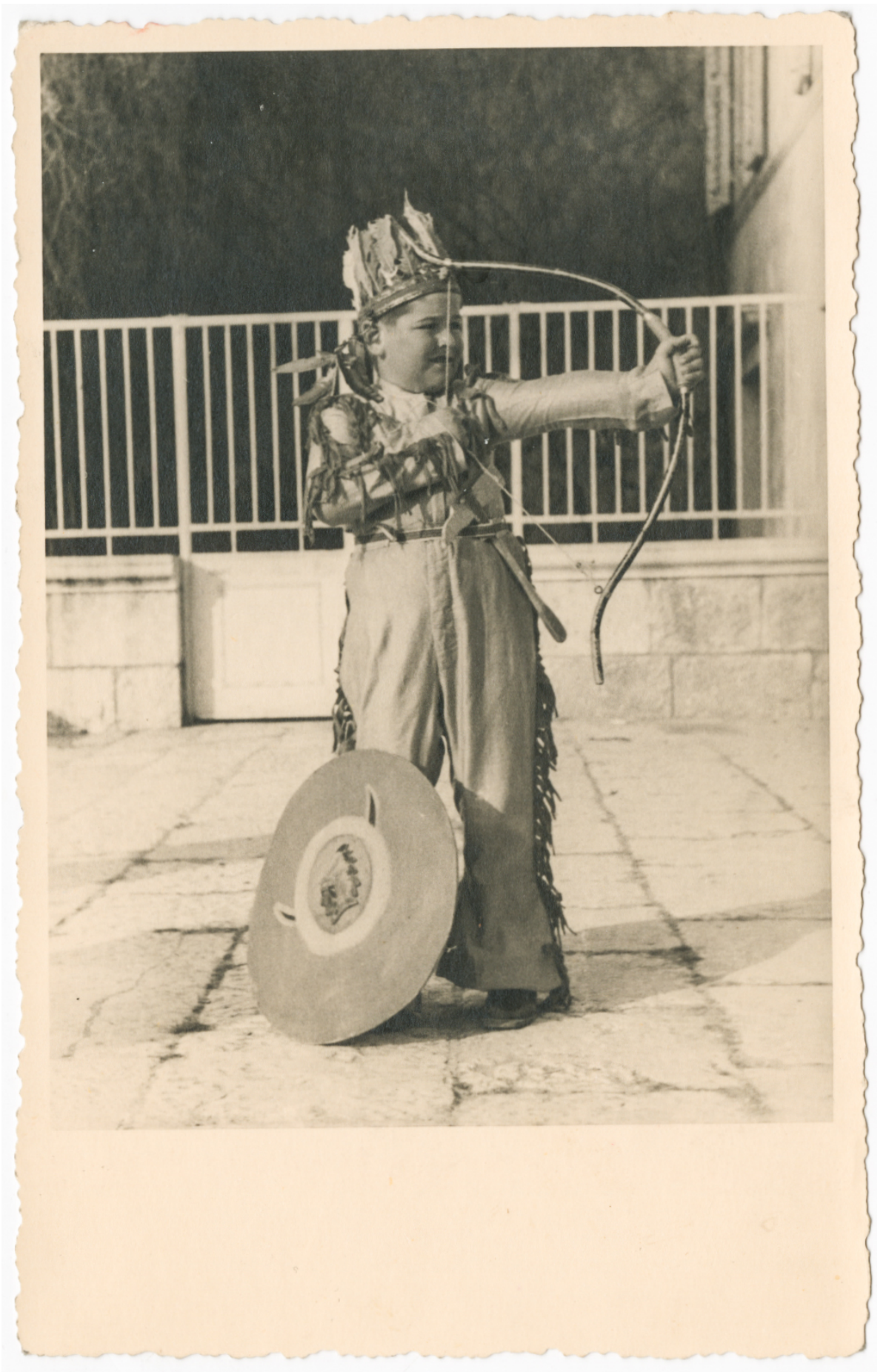

Figure 43. Photograph of a young boy dressed in "Indian" costume with a shield, aiming a bow and arrow, early $20^{\text {th }}$ century. Gelatin silver print. First Nations Collection at the Archive of Modern Conflict Toronto. 

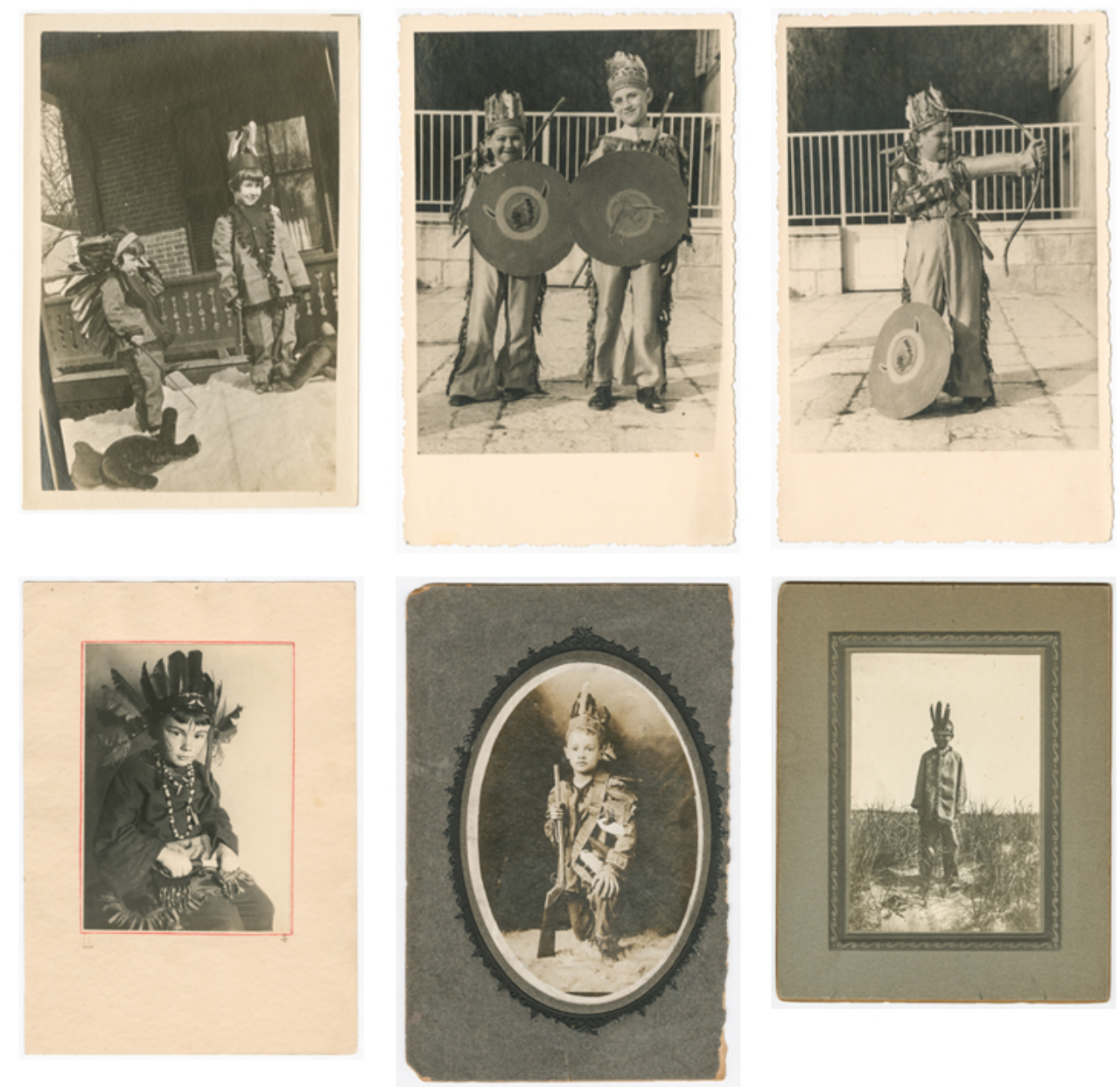

Figure 44. Clockwise from top left:

Two children in front of house in costume "playing Indian" in the snow, $20^{\text {th }}$ century. Gelatin silver print. First Nations Collection at the Archive of Modern Conflict Toronto.

Two young boys dressed in "Indian" costume holding shields, early $20^{\text {th }}$ century. Gelatin silver print. First Nations Collection at the Archive of Modern Conflict Toronto.

Photograph of a young boy dressed in "Indian" costume with a shield, aiming a bow and arrow, early $20^{\text {th }}$ century. Gelatin silver print. First Nations Collection at the Archive of Modern Conflict Toronto.

A young boy in "Indian" costume standing in a field of sand and grass, 1908 Inscription on verso reads: "Elmer at Plum Island Aug 9 1908 ." Gelatin silver print mounted on card. First Nations Collection at the Archive of Modern Conflict Toronto.

Studio portrait of a young boy dressed in Plains-inspired Indian costume with tomahawk and face paint, 1933. Inscription on recto reads: "LuLu,." Gelatin silver print on matte paper. First Nations Collection at the Archive of Modern Conflict Toronto.

Studio portrait of a young boy dressed in "Indian" costume, kneeling and holding a rifle, late $19^{\text {th }}$ century. Albumen print mounted on card. First Nations Collection at the Archive of Modern Conflict Toronto. 


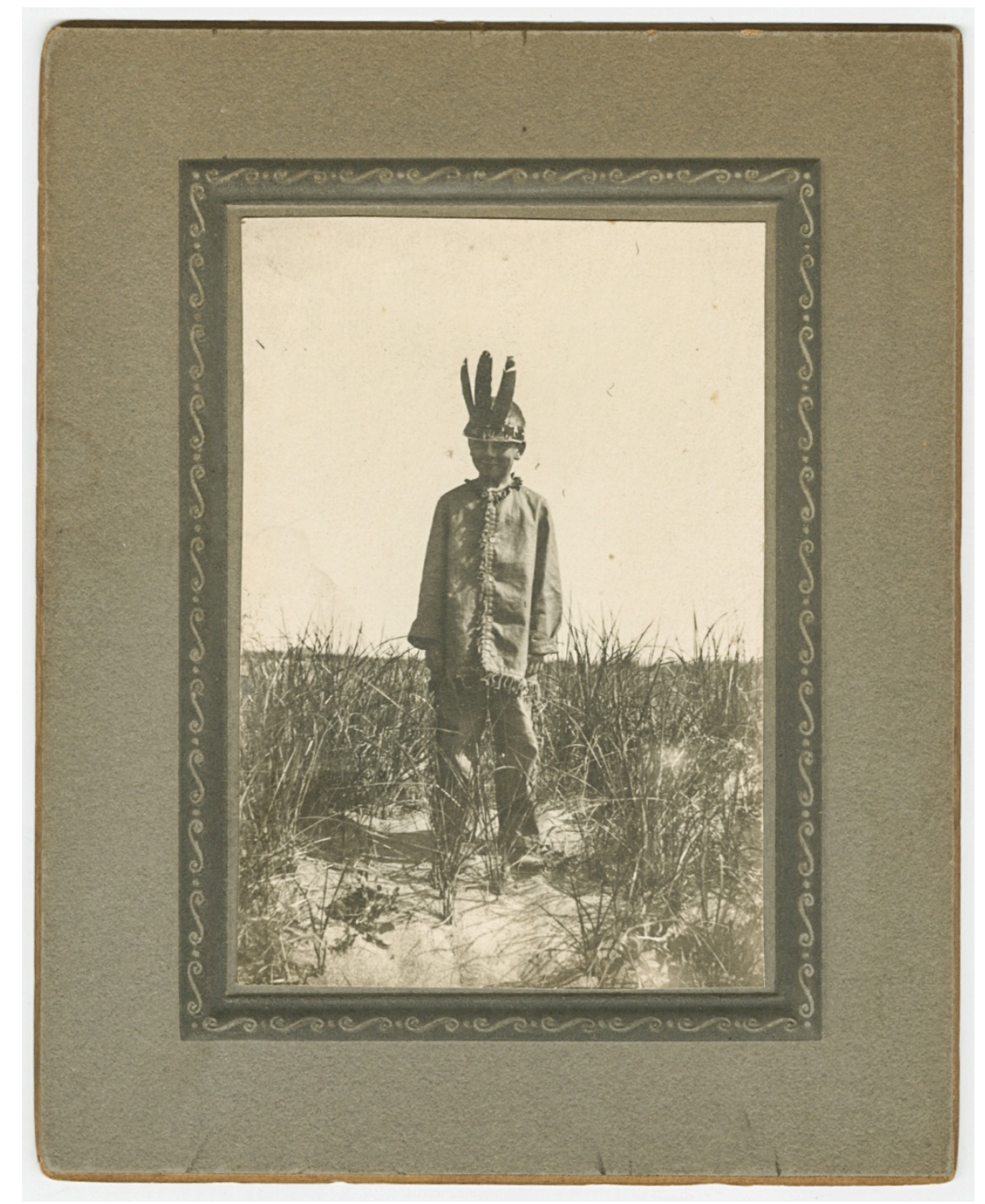

Figure 45. A young boy in "Indian" costume standing in a field of sand and grass, 1908. Inscription on verso reads: "Elmer at Plum Island Aug $9^{\text {th }}$ 1908." Gelatin silver print mounted on card. First Nations Collection at the Archive of Modern Conflict Toronto. 


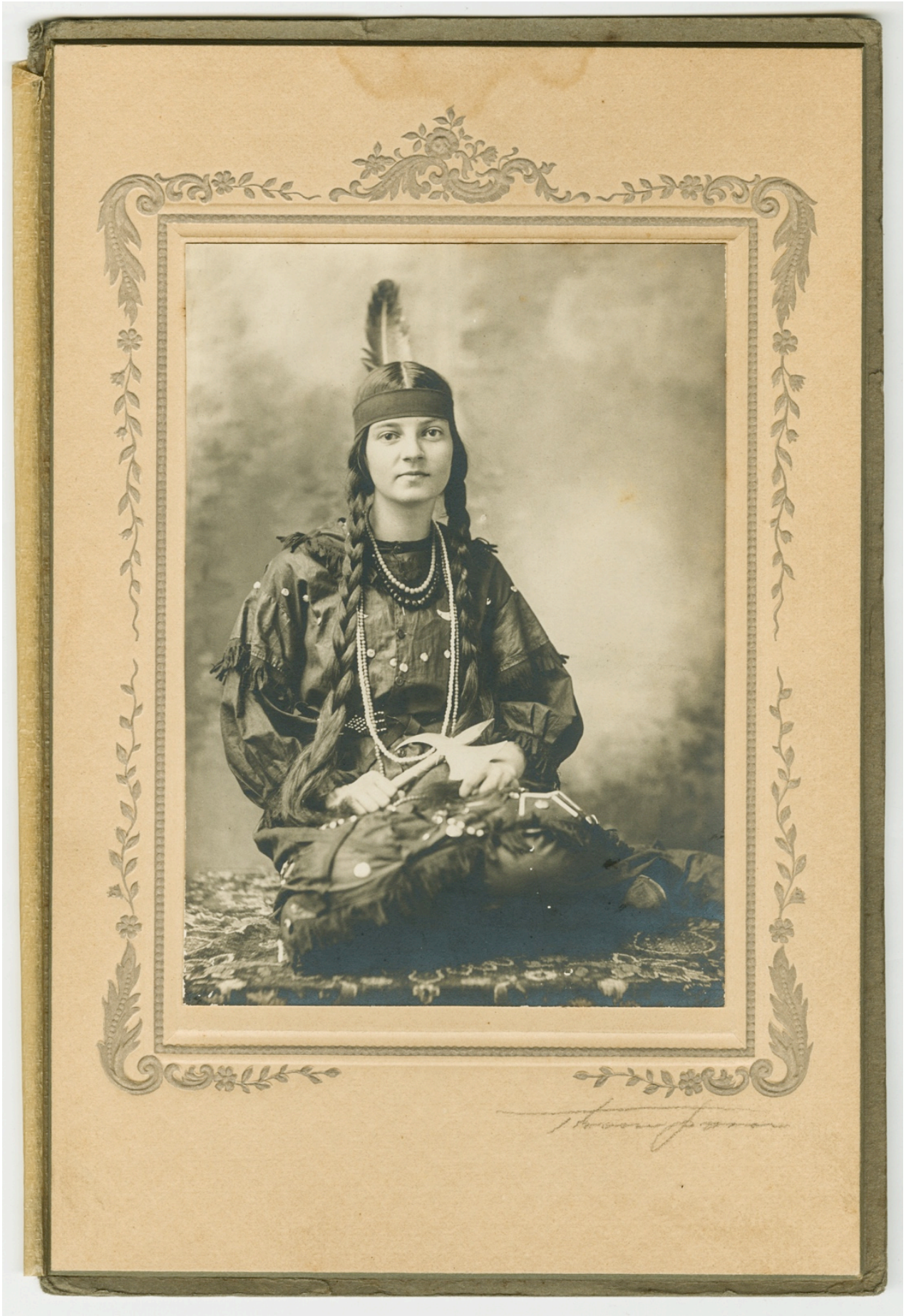

Figure 46. Studio portrait of a girl dressed in "Indian" costume, sitting on a tapestry and holding a tomahawk, late $19^{\text {th }}$ to early $20^{\text {th }}$ century. Gelatin silver print mounted on card. First Nations Collection at the Archive of Modern Conflict Toronto. 


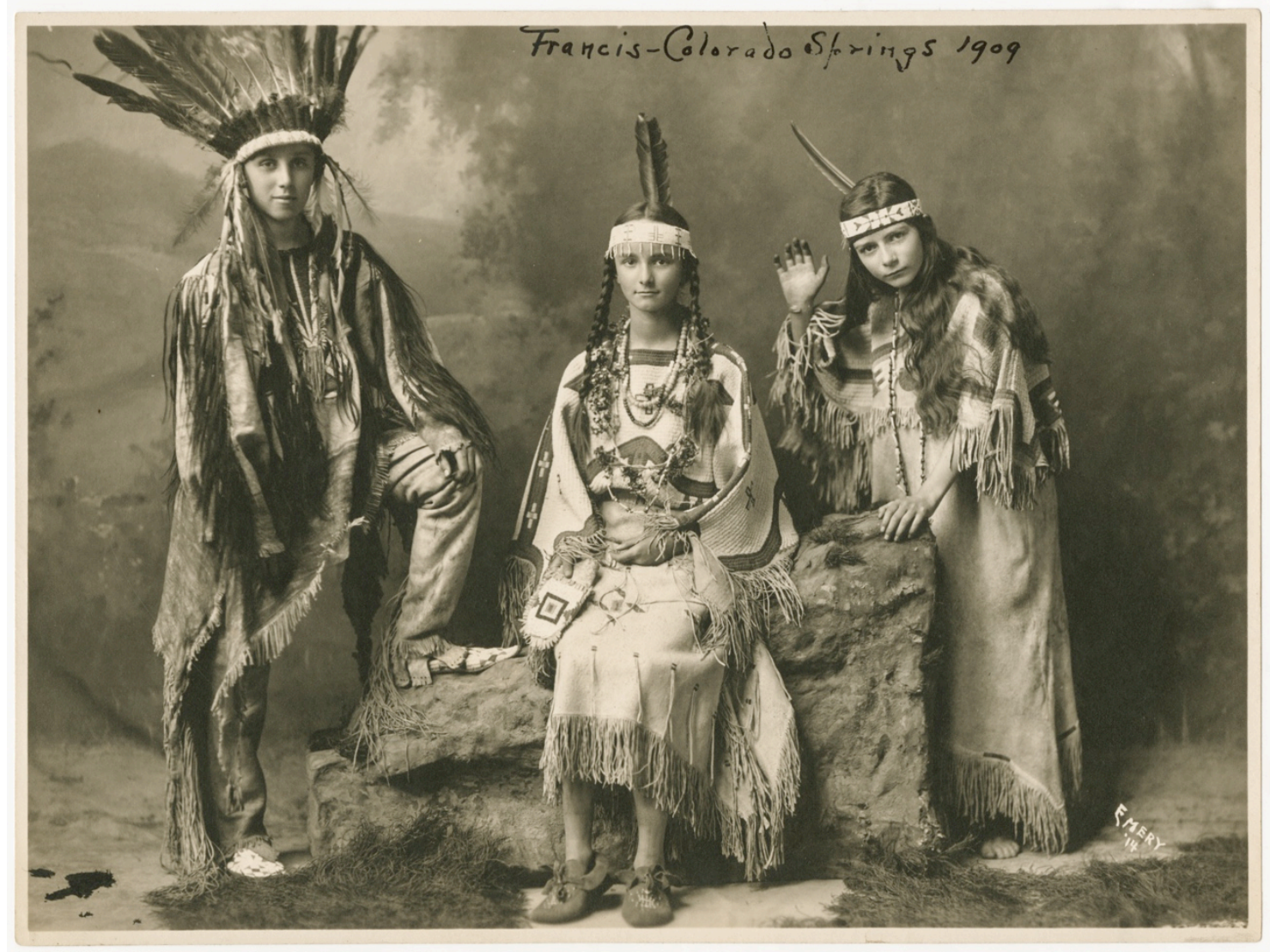

Figure 47. Studio portrait of two girls and one boy dressed in Plains "Indian" costume, posed against an "outdoor" studio set. Inscription on recto reads: "Francis-Colorado Springs, 1909." Gelatin silver print. First Nations Collection at the Archive of Modern Conflict Toronto. 


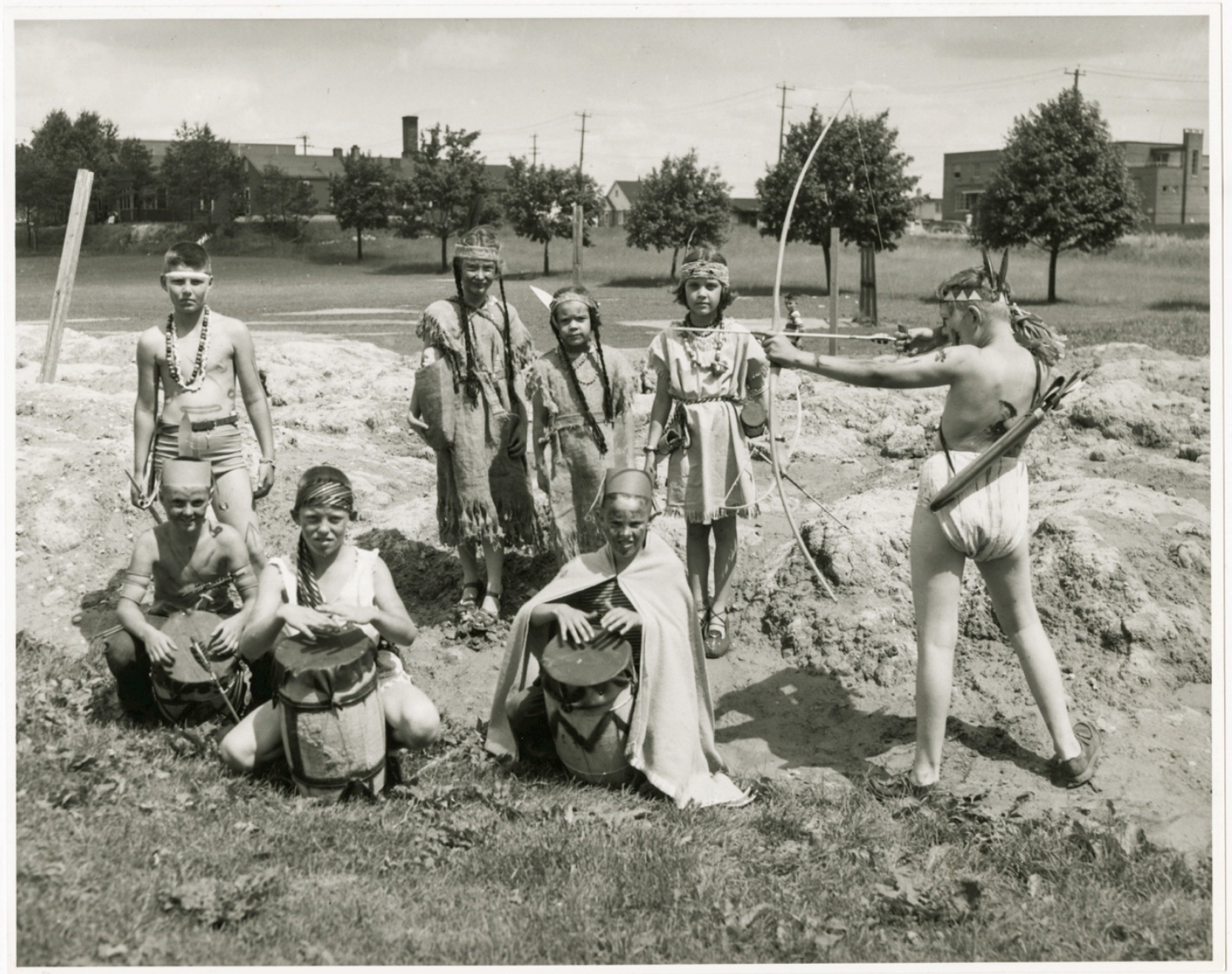

Figure 48. Eight children dressed in Plains-inspired "Indian" costume, one aiming a bow and arrow and three children playing hand drums, $20^{\text {th }}$ century. Gelatin silver print. Record Photography Collection of the University of Waterloo Library. First Nations Collection at the Archive of Modern Conflict Toronto. 


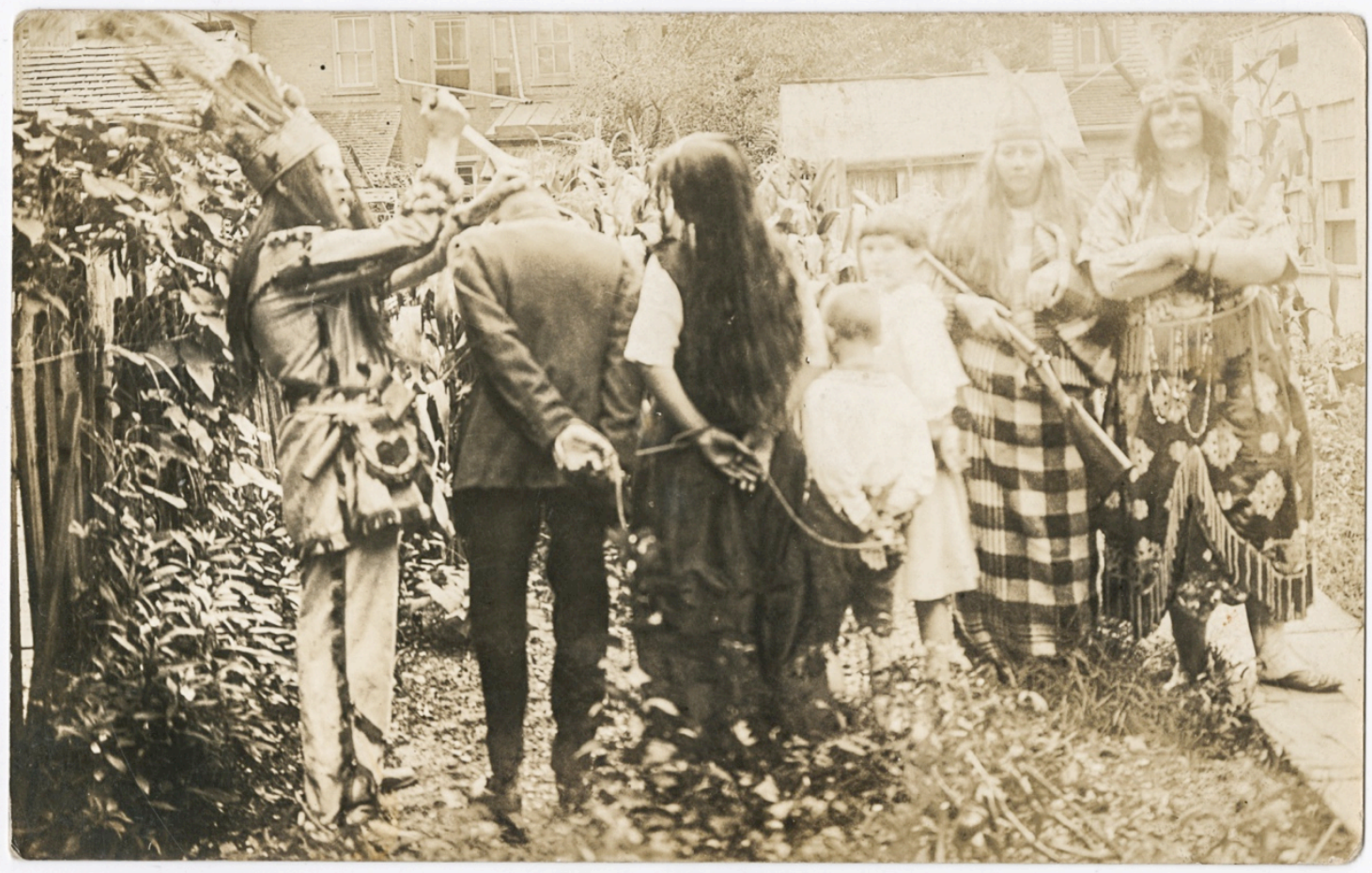

Figure 49. Real photo postcard of family of adults and children playing "Indians" and "settlers" where one man is being scalped and the others have their hands tied, ca.1915. Gelatin silver print. First Nations Collection at the Archive of Modern Conflict Toronto. 

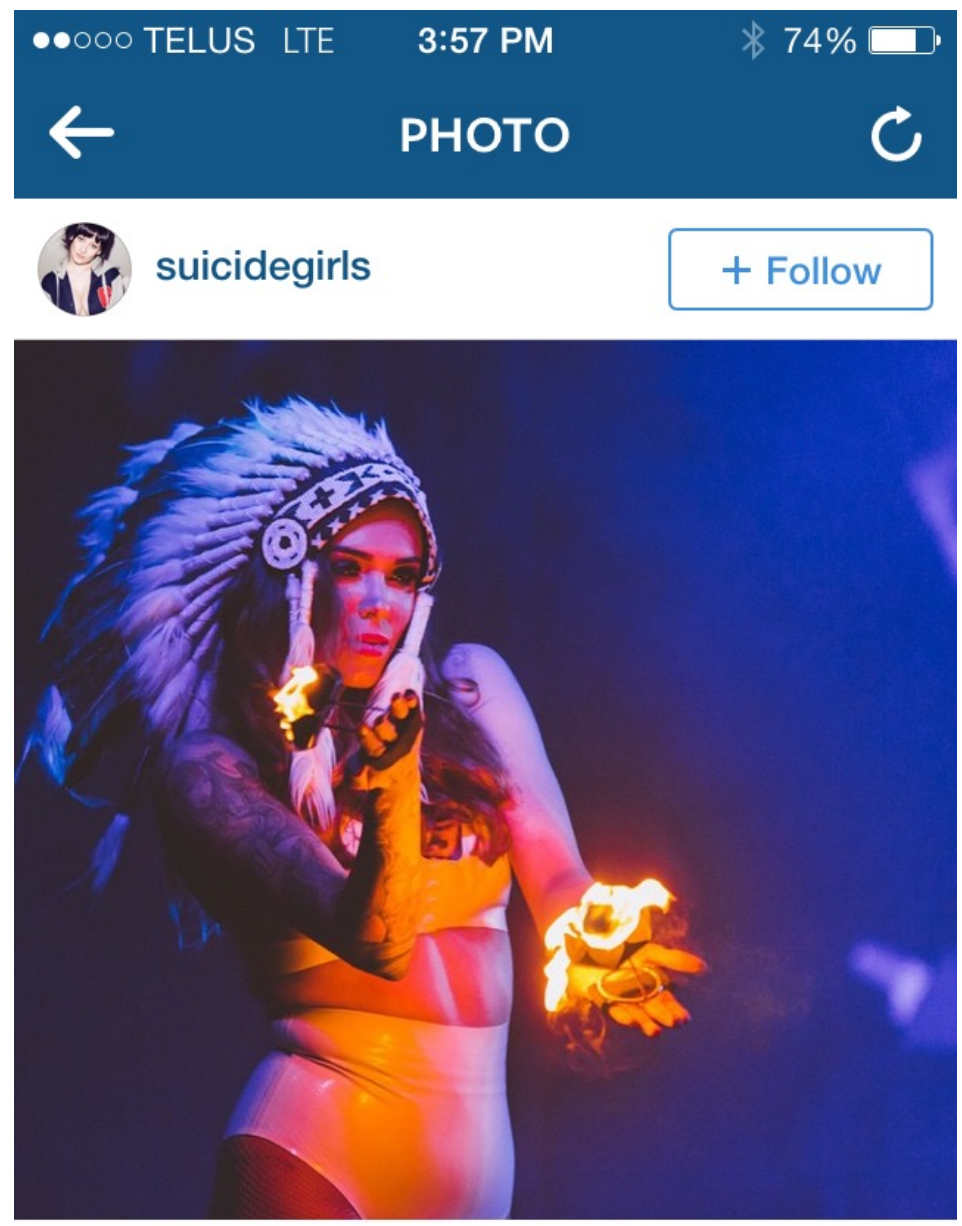

Based on people you follow

$4 \mathrm{~h}$

\section{7,672 likes}

suicidegirls \#SuicideGirls are coming.... Get your tickets to a @SGBlackheartBurlesque show near you! \#BlackheartBurlesque.com \#SuicideGirls \#burlesque

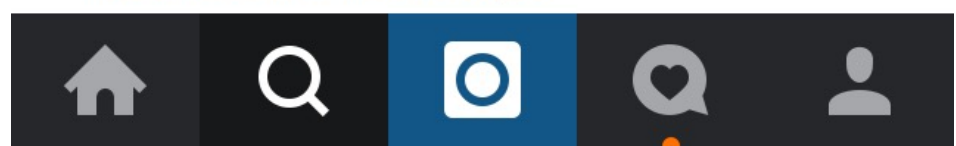

Figure 50. Screen capture of @ suicidegirls instagram account of a photograph posted of a model wearing a long feathered war bonnet, 2015. @SGBlackheartburlesque. Digital photograph. Personal Collection. 


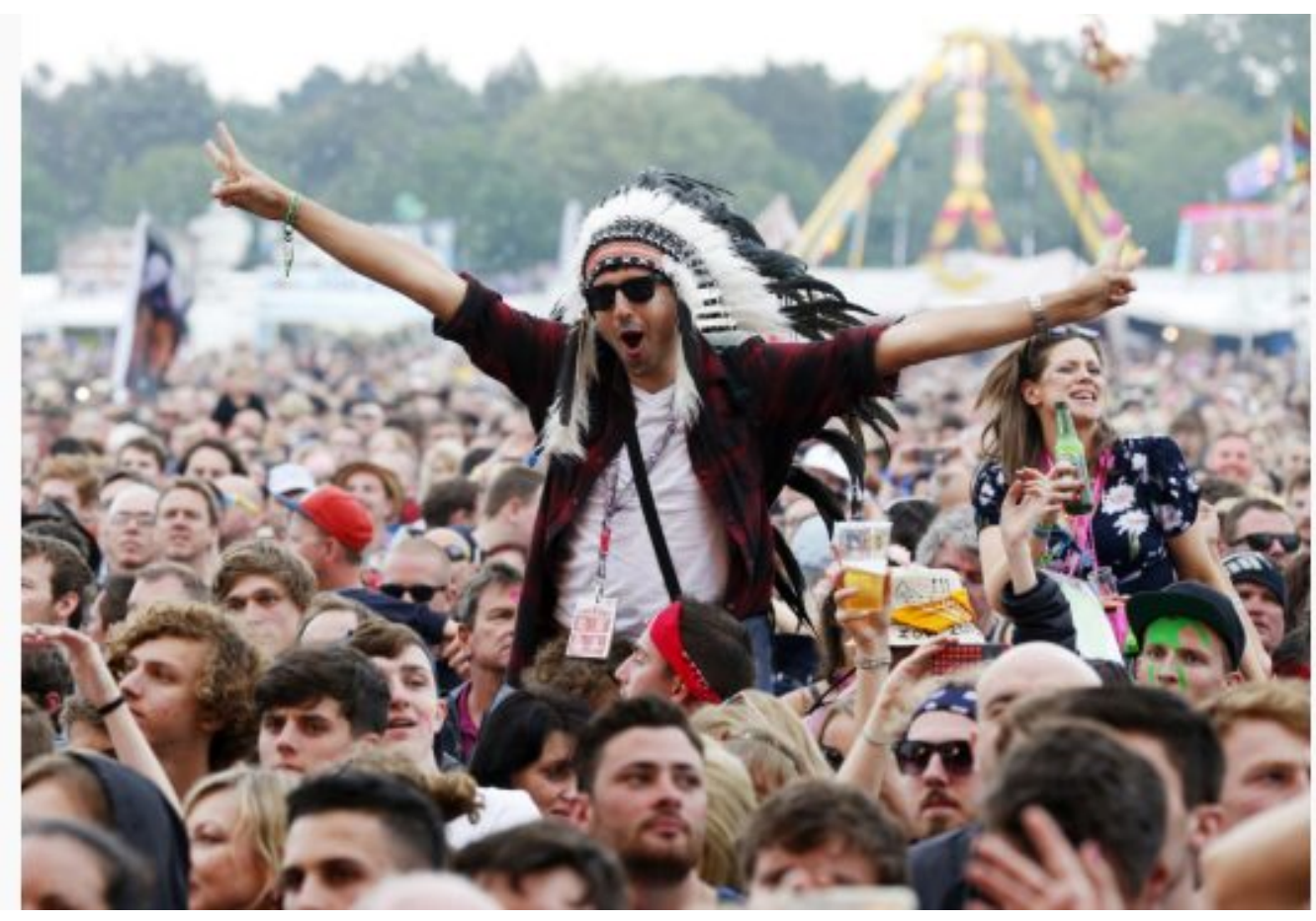

Figure 51. A music fan in a Native American headdress at the Isle of Wight Festival in the United Kingdom, June 2015. Jim Ross/Invision. Digital Photograph.

http://www.thestar.com/entertainment/2015/07/15/ontario-alberta-music-festivals-ban-wearingfirst-nations-headdresses.html 


\section{Bibliography}

Adam, Hans Christian. Edward S. Curtis. Köln: Taschen, 1999.

Barthes, Roland. The Fashion System. Berkeley and Los Angeles: University of California Press Ltd., 1990.

Behdad, Ali, and Luke Gartlan. Photography's Orientalism: New Essays on Colonial Representation. Los Angeles: Getty Research Institute, 2013.

Bellin, Joshua David, and Laura L. Mielke, eds. Native Acts: Indian Performances, 16031832. Lincoln: University of Nebraska Press, 2011.

Belous, Russell E., and Robert A. Weinstein. Will Soule: Indian Photographer at Fort Sill,Oklahoma 1869-74. Los Angeles: The Ward Ritchie Press, 1969.

Berkhofer, Robert F., Jr. The White Man's Indian: Images of the American Indian from Columbus to the Present. New York: Alfred A. Knopf, Inc., 1978.

Bird, Elizabeth S., ed. Dressing in Feathers: The Construction of the Indian in American Popular Culture. Boulder: Westview Press, 1996.

Brasser, Theodore. Native American Clothing: An Illustrated History. Buffalo, New York and Richmond Hill, Ontario: Firefly Books Ltd., 2009.

Brown, Dee. Bury My Heart at Wounded Knee: An Indian History of the American West. New York: Picador, Henry Holt and Company, 1970.

Calloway, Colin G. First Peoples: A Documentary Survey of American Indian History. Boston: Bedford/St. Martin's, 2008.

Coleman, Daniel. White Civility: The Literary Project of English Canada. Toronto: University of Toronto Press Incorporated, 2006.

Cooper, Cynthia. Magnificent Entertainments: Fancy Dress Balls of Canada's Governors General, 1876-1898. Ottawa: Goose Lane Editions, Canadian Museum of Civilization, 1997.

Deloria, Philip J. Indians in Unexpected Places. Lawrence: University Press of Kansas, 2004.

Deloria, Philip J. Playing Indian. New Haven and London: Yale University Press. 1998.

Eakins, P.R. "VENNOR, HENRY GEORGE.” In Dictionary of Canadian Biography, vol. 11. University of Toronto/Université Laval, 2003. Accessed July 8, 2015. http://www.biographi.ca/en/bio/vennor_henry_george_11E.html.

Earling, Debra. Beyond the Reach of Time and Change: Native American Reflections on the Frank A. Rinehart Photograph Collection. Tucson: University of Arizona Press, 2005. 
Eccles, W. J., and John E. Foster. "Fur Trade." In The Canadian Encyclopedia. Historica Canada, 1985. Article published July 24, 2013.

Ewers, John Canfield. "The Emergence of the Plains Indian as the Symbol of the North American Indian." In Indian Life on the Upper Missouri. Oklahoma: University of Oklahoma Press, 1968.

Fisher, Donald M. Lacrosse: A History of the Game. Baltimore: Johns Hopkins University Press, 2002.

Fowler, Don D., and Rachel J. Homer. In a Sacred Manner We Live: Photographs of the North American Indian by Edward S. Curtis. Barre, Massachusetts: Barre Publishers, 1973.

Francis, Daniel. The Imaginary Indian: The Image of the Indian in Canadian Culture. Vancouver: Arsenal Pulp, 1992.

Francis, Margot. Creative Subversions: Whiteness, Indigeneity, and the National Imaginary. Vancouver: UBC Press, 2011.

Francis, Margot. "Reading the Autoethnographic Perspectives of Indians 'Shooting Indians,," TOPIA: Canadian Journal of Cultural Studies, Topia 7, pp. 5-26, 2002.

Gidley, M. The Vanishing Race: Selections from Edward S. Curtis' The North American Indian. Seattle: University of Washington Press, 1987.

Green, Rayna. "The Pocahontas Perplex: The Image of Indian Women in American Culture." The Massachusetts Review 16, no. 4 (Autumn, 1975): 698-714. Accessed September 3, 2015. http://www.jstor.org/stable/25088595.

Green, Rayna. "The Tribe Called Wannabee: Playing Indian in America and Europe." Folklore 99, no. 1 (1988): 30-55. Taylor \& Francis, Ltd. on behalf of Folklore Enterprises, Ltd. http://www.jstor.org/stable/1259567.

Guerrero, James. "Patriarchal Colonialism and Indigenism: Implications for Native Feminist Spirituality and Native Womanism," Indigenous Women in the Americas (Spring, 2003): 58-69. Wiley on behalf of Hypatia, Inc. Accessed August 18, 2015. http://www.jstor.org/stable/3811011.

Harvey, John. Men in Black. Chicago: University of Chicago Press, 1995.

Hathaway, Nancy. Native American Portraits 1862-1918. San Francisco: Chronicle Books, 1990.

Hiesinger, Ulrich W. Indian Lives: A Photographic Record from the Civil War to Wounded Knee. Munich and New York: Prestel-Verlag, 1994.

Hight, Eleanor, M., and Gary D. Sampson, eds. Colonialist Photography: Imag(in)ing Race and Place. New York, NY: Routledge, 2002.

Hirschfelder, Arlene B. American Indian Stereotypes in the World of Children: A Reader 
and Bibliography. Metuchen, NJ: The Sacrecrow Press, Inc., 1982.

Huhndorf, Shari M. Going Native: Indians in the American Cultural Imagination. Ithaca: Cornell University Press, 2001.

Hutchinson, Elizabeth. The Indian Craze: Primitivism, Modernism, and Transculturation in American Art, 1890-1915. Durham and London: Duke University Press, 2009.

Innis, Harold Adams. The Fur Trade in Canada: An Introduction to Canadian Economic History. Toronto: University of Toronto Press, 1970.

Kilpatrick, Jacquelyn. Celluloid Indians: Native Americans and Film. Lincoln and London: University of Nebraska Press, 1999.

King, Thomas. The Inconvenient Indian: A Curious Account of Native People in North America. Anchor Canada, 2013.

Lawrence, Bonita. "Gender, Race, and the Regulation of Native Identity in Canada and the United States: An Overview." Hypatia 18, no. 2 (Spring 2003): 3-31.Wiley on behalf of Hypatia, Inc. Accessed August 18, 2015. http://www.jstor.org/stable/3811009.

Lidchi, Henrietta, and Hulleah J. Tsinhnahjinnie, ed(s). Visual Currencies: Reflections on Native Photography. Edinburgh: National Museums Scotland Enterprises Limited, 2009.

Lippard, Lucy, ed. Partial Recall: With Essays on Photographs of Native North Americans. New York: New Press, 1992.

Masquerade and Carnival. London and New York: The Butterick Publishing Co. Limited, 1892.

Maxwell, Anne. Colonial Photography and Exhibitions: Representations of the Native and the Making of European Identities. Leicester: Leicester University Press, 2000.

McGrath, Ann. "Playing Colonial: Cowgirls, Cowboys, and Indians in Australia and North America." Journal of Colonialism and Colonial History 2, no. 1 (2001). Accessed August 18, 2015. https://muse.jhu.edu/.

Miller, Bonnie M. "The Incoherencies of Empire: The "Imperial” Image of the Indian at the Omaha World's Fairs of 1898-99." Journal of American Studies 49, no. 3/4 (Fall/Winter 2008): 39-62.

Moyles, R.G., and Doug Owram. Imperial Dreams and Colonial Realities: British Views of Canada, 1880-1914. Toronto: University of Toronto Press, 1988.

Ortiz, Simon J. Beyond the Reach of Time and Change: Native American Reflections on the Frank A. Rinehart Photograph Collection. Tucson: The University of Arizona Press, 2004.

Parsons, Sarah. William Notman: Life \& Work. Toronto: The Art Institute, 2014.

Paskievich, John, and David Scheffel. If Only I Were an Indian. Directed by John 
Paskievich. Canada: National Film Board of Canada, 1996.

Paterek, Josephine. Encyclopedia of American Indian Costume. Santa Barbara: ABCCLIO, Inc., 1994.

Paul, Daniel N. We Were Not The Savages: Collision Between European and Native North American Civilizations. Halifax: Fernwood Publishing, 2006.

Reynolds, Charles R., Jr. American Indian Portraits from the Wanamaker Expedition of 1913. Brattleboro, Vermont: The Stephen Greene Press, 1973.

Silversides, Brock V. The Face Pullers: Photographing Native Canadians, 1871-1939. Saskatoon, Saskatchewan: Fifth House Limited, 1994.

Smith, Linda Tuhiwai. Decolonizing Methodologies: Research and Indigenous Peoples. New York: Zed Books, Ltd.,1999.

Stevens, Laura M. The Poor Indians: British Missionaries, Native Americans, and Colonial Sensibility. Philadelphia: University of Pennsylvania Press, 2004.

Sutton, Royal. The Face of Courage: Indian Photographs of Frank A. Rinehart. Fort Collins, Colorado: Old Military Press, 1972.

Triggs, Stanley G. The Composite Photograph, McCord Museum of Canadian History, 2005.

Triggs, Stanley G. The Man and the Studio, McCord Museum of Canadian History, 2005.

Touchie, Rodger D. Edward S. Curtis Above the Medicine Line: Portraits of Aboriginal Life in the Canadian West. Vancouver: Heritage House Publishing Company, 2010.

Vennum, Thomas. American Indian Lacrosse: Little Brother of War. Baltimore: The Johns Hopkins University Press, 1994.

Vickers, Scott B. Native American Identities: From Stereotype to Archetype in Art and Literature. Albuquerque: University of New Mexico Press, 1998.

Vodden, C., and L.A. Frieday. "Geological Survey Of Canada." In The

Canadian Encyclopedia. Historica Canada, 1985. Article published February 8, 2006.

Wall, Sharon. "Totem Poles, Teepees, and Token Traditions: playing Indian at Ontario Summer Camps." The Canadian Historical Review 86, no. 3 (September 2005).

West, Thomas J. “BEERS, WILLIAM GEORGE.” In Dictionary of Canadian Biography, Vol. 12. University of Toronto/Université Laval, 2003. Accessed July 9, 2015. http://www.biographi.ca/en/bio/beers_william_george_12E.html.

Wightman, William Robert. Forever on the Fringe: Six Studies in the Development of the Manitoulin Island. Toronto: University of Toronto Press, 1982. 